\title{
UTILIZAÇÃO DE CONTRATOS FUTUROS AGROPECUÁRIOS EM CARTEIRAS DE INVESTIMENTOS: UMA ANÁLISE DE VIABILIDADE
}

\section{FABIO LANHOSO DE MATTOS}

Dissertação apresentada à Escola Superior de Agricultura "Luiz de Queiroz", Universidade de São Paulo, para obtenção do título de Mestre em Ciências, Área de Concentração: Economia Aplicada.

PIRACICABA

Estado de São Paulo - Brasil

Julho - 2000 


\section{UTILIZAÇÃO DE CONTRATOS FUTUROS AGROPECUÁRIOS EM CARTEIRAS DE INVESTIMENTOS: UMA ANÁLISE DE VIABILIDADE}

\section{FABIO LANHOSO DE MATTOS}

Bacharel em Ciências Econômicas

Orientador: Prof. Dr. JOAQUIM BENTO DE SOUZA FERREIRA FILHO

Dissertação apresentada à Escola Superior de Agricultura "Luiz de Queiroz", Universidade de São Paulo, para obtenção do título de Mestre em Ciências, Área de Concentração: Economia Aplicada.

PIRACICABA

Estado de São Paulo - Brasil

Julho -2000 
Dados Internacionais de Catalogação na Publicação (CIP) DIVISÃO DE BIBLIOTECA E DOCUMENTAÇÃO - Campus “Luiz de Queiroz”/USP

Mattos, Fabio Lanhoso de

Utilização de contratos futuros agropecuários em carteiras de investimentos: uma análise de viabilidade / Fabio Lanhoso de Mattos. - - Piracicaba, 2000.

$104 \mathrm{p}$.

Dissertação (mestrado) - - Escola Superior de Agricultura Luiz de Queiroz, 2000.

Bibliografia.

1. Bolsa de futuros 2. Bolsa de mercadorias 3. Investimento agrícola 4.

Mercado financeiro 5. Mercado futuro I. Título

CDD 338.13

"Permitida a cópia total ou parcial deste documento, desde que citada a fonte - $\mathrm{O}$ autor" 


\section{AGRADECIMENTOS}

À minha família, especialmente meus pais, que sempre destacaram a importância dos estudos e me apoiaram em todos os momentos.

Ao professor Bento, pela orientação, paciência e amizade demonstrados durante todo o curso. Sem sua ajuda, a conclusão deste trabalho certamente seria mais difícil.

Ao professor Millan, pelas críticas e sugestões em todas as etapas do trabalho, sem as quais a qualidade desta dissertação ficaria comprometida. Um agradecimento especial também aos professores Geraldo, Adriano e João pelas valiosas contribuições em diversas fases do trabalho.

À USP e ao CNPq, que ofereceram o suporte necessário para o bom aproveitamento do curso de pós-graduação.

Aos professores e amigos Zilda, João, Adriano e Paulo Cidade, que me deram diversas oportunidades e bastante "trabalho", mas que muito contribuíram para meu aprendizado.

A todos os professores do Departamento de Economia, Administração e Sociologia da ESALQ-USP, em especial ao professor Hoffmann, pelos ensinamentos oferecidos.

Aos funcionários do Departamento de Economia, Administração e Sociologia da ESALQUSP, pela atenção e dedicação demonstradas em todos os momentos: Maeilli, Cris, Helena, Pedro, Valdeci, Márcia, Elenice, Maria Helena, Silvana, Angélica e Ligiana. Um agradecimento especial à $\mathrm{Lu}$, pela amizade sempre presente. Com certeza, todos eles tornaram o curso de pós-graduação mais agradável.

Às amigas e estagiárias da biblioteca: Balan (a prima), Nora (que ainda me deve uma "roda"), Aninha e Seve. 
Aos amigos de todas as horas: Mau (o capixaba-mor), Bigas (o soro-querubim), Gau (o gaúcho paulista) e Válter (o bugrão com B maiúsculo). Pela convivência, pelas discussões acaloradas, pelos churrascos, pelas partidas de basquete e por tantas outras que somente os verdadeiros amigos sabem compartilhar.

Aos colegas da turma de 97, Dani, Sylvia, Danilo, Néia, Ari, Tião, Ana, Yaskara, Marcos, Tomás, Melissa, Maristella, Umberto, Flávio e Marcellus. Com eles os momentos de estudo eram mais proveitosos e os momentos de lazer mais animados.

Aos colegas de república, pela amizade e pela convivência sempre divertida: Bruno, Renatão, Emerson, Marcelo, Ona, Zé, Glauco, Gonça e Cadu.

Aos amigos do curso de pós-graduação: Vânia (minha grande amiga serelepe), Jaênes e Cândida (os baianos arretados), Carlos Augusto (o bom baiano), Canziani, Patrizia, Robertinho, Pedrão (o parente), Sílvia, Sérgio, Fabiana, Ary, Robson, Daltro, Cassiana, Carla e tantos outros que a falta de espaço me impede de citar, mas que sempre terão lugar garantido em minhas melhores lembranças.

Aos amigos da "velha guarda": Ly (que "dormiu" em Piracicaba), Alê (que não quis experimentar a piapara), Alemão (que ficou me devendo uma visita), Heleninha, De, Batata (meu agente de mudanças), Fuka, Elina e Valéria.

Ao pessoal da Tendências, pela amizade e incentivo constantes. Um agradecimento especial à $\mathrm{Lu}$, pela cuidadosa revisão do texto (se ainda persistirem erros, a culpa é da minha teimosia em aceitar suas sugestões).

Aos alunos dos cursos de graduação da ESALQ-USP, com os quais tive a oportunidade de ensinar e ao mesmo tempo aprender.

À Dani, que tornou os maus momentos agradáveis e fez os bons momentos ficarem ainda melhores. 


\section{SUMÁRIO}

1 - Introdução .................................................................................................... 7

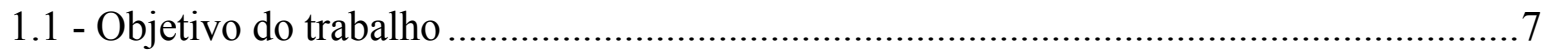

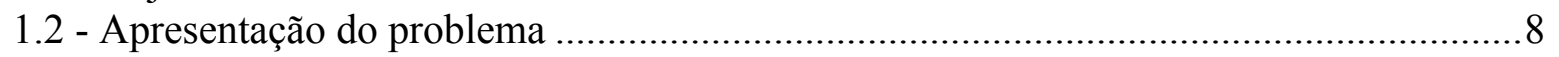

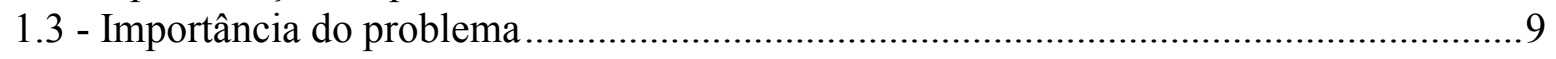

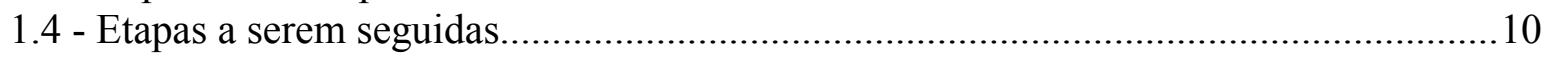

2 - Risco e retorno .............................................................................................. 12

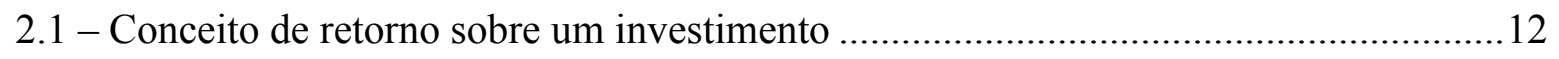

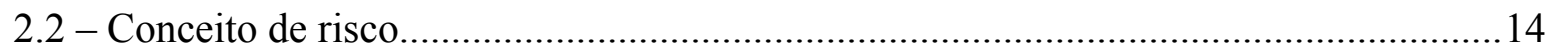

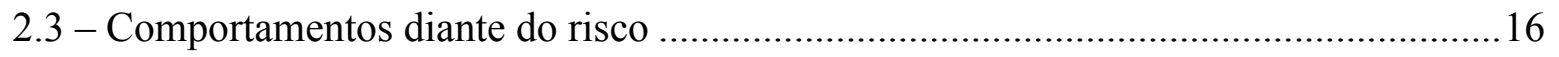

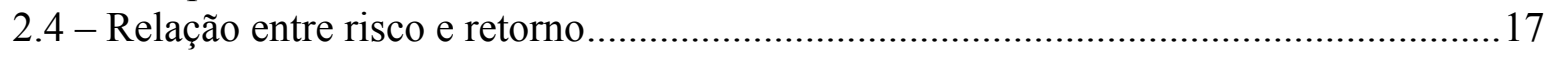

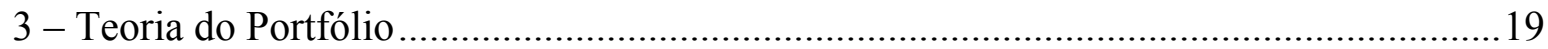

3.1 - Breve histórico ................................................................................................... 19

3.2 - Formulação da Teoria do Portfólio ..........................................................................20

3.3 - Conceito básico da Teoria do Portfólio .....................................................................24

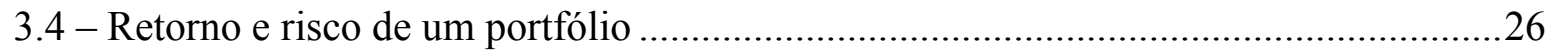

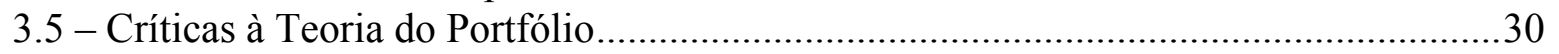

3.6 - Avaliação do desempenho de uma carteira: o Índice de Sharpe .................................33

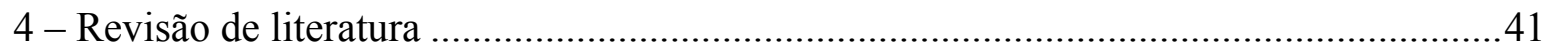

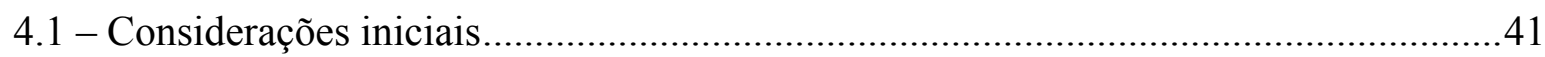

4.2 - Apresentação dos trabalhos já realizados sobre o assunto .....................................42

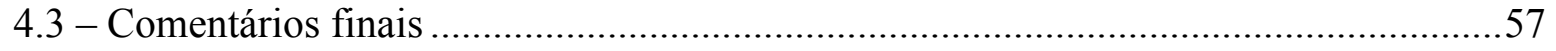

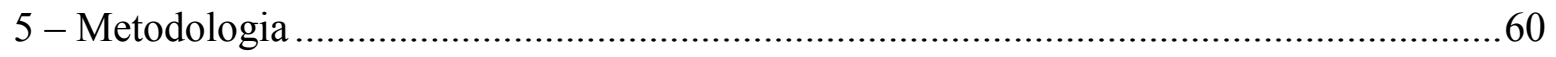

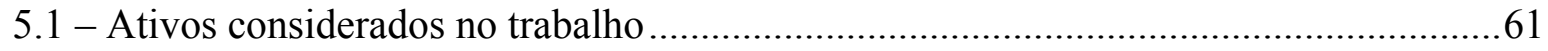

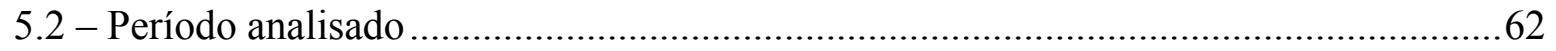

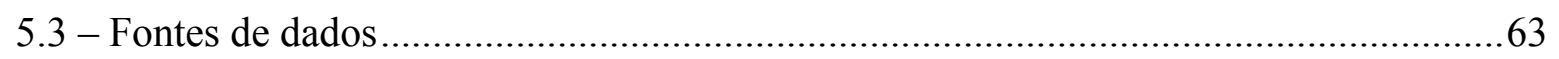

5.4 - Cálculo das taxas de retorno de cada ativo e das carteiras......................................63

5.5 - Cálculo do risco de cada ativo e das carteiras....................................................66

5.6 - Análise do coeficiente de correlação entre os retornos de ações e contratos futuros

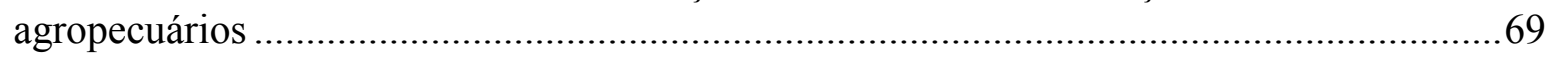

5.7 - Carteiras combinando ações e contratos futuros agropecuários ................................72 
6 - Resultados ..... 78

6.1 - Análise da relação retorno-risco de uma carteira de ações e de cada um dos contratos futuros agropecuários durante o período analisado...... .78 6.2 - Verificação da correlação entre os retornos de ações e contratos futuros agropecuários

6.3 - Comparação dos desempenhos de uma carteira composta por ações e de outra composta por ações e um contrato futuro agropecuário. 88 6.4 - Verificação da viabilidade de se construir carteiras eficientes por meio da combinação de ações e contratos futuros agropecuários ...............................................................98

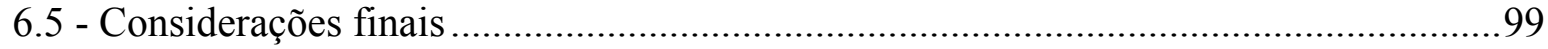

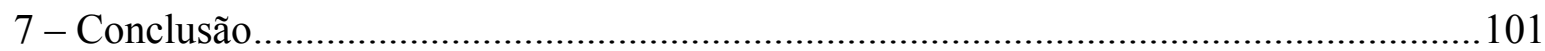

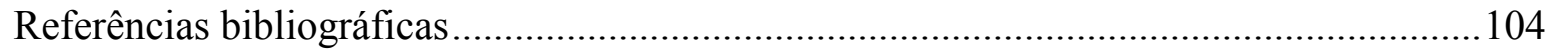




\section{1 - INTRODUÇÃO}

"Our lives teem with numbers, but we sometimes forget that numbers are only tools. They have no soul; they may indeed become fetishes".

Peter L. Bernstein

A palavra portfólio tem sua origem no latim e deriva de portare, que significa carregar, e foglio, que significa folha ou papel. Portfólio passou então a ser entendido como um conjunto de ativos1 possuído por um indivíduo. Estes podem ser ativos reais, como uma casa ou um carro, ou ativos financeiros, como ações e títulos. Neste trabalho, o termo carteira de investimentos, ou simplesmente carteira, será usado com o mesmo sentido de portfólio.

No mundo financeiro, investidores montam carteiras de investimento com o claro intuito de, respeitadas certas restrições, obter os maiores ganhos possíveis incorrendo nos menores níveis de risco possíveis. A composição destas carteiras pode ser o resultado de uma série de decisões independentes e aleatórias ou pode advir de um meticuloso processo de planejamento (Elton \& Gruber, 1995). Este trabalho irá se preocupar apenas com a segunda alternativa.

\section{1 - Objetivo do trabalho}

O objetivo principal deste trabalho é analisar o potencial de utilização de contratos futuros agropecuários na composição de carteiras de investimento em ações, enfatizando-se o poder de redução de risco associado à estratégia de se manter tais ativos em uma carteira de investimentos.

\footnotetext{
${ }^{1}$ Bens que oferecem um fluxo de serviços ao longo do tempo (Simonsen, 1983).
} 


\section{2 - Apresentação do problema}

Segundo a Teoria do Portfólio, a composição de carteiras de investimento combinando ativos que apresentam correlação inferior a um entre seus retornos individuais torna possível reduzir o risco da carteira sem prejudicar o retorno da mesma. Como será discutido posteriormente, tal objetivo (menor risco para um mesmo nível de retorno) é altamente desejado por qualquer administrador de carteiras de investimento.

Uma correlação inferior a um entre os retornos de dois ativos significa, grosso modo, que ambos não tendem a apresentar o mesmo comportamento no decorrer do tempo. Quanto menor for esta correlação, menos semelhante será o comportamento dos retornos ao longo do tempo. Por exemplo, o fato do retorno de um desses ativos estar decrescendo não implica, necessariamente, que o retorno do outro também esteja. Em outras palavras, os fatores que determinam o comportamento do retorno de um ativo não são (pelo menos de forma determinante) os mesmos que determinam o comportamento do retorno do outro ativo.

À primeira vista pode parecer claro que os retornos de ativos financeiros (como ações e títulos) e commodities agropecuárias têm seus comportamentos ditados por fatores distintos, visto que ambos são de natureza bastante diversa. Também parece razoável acreditar que a correlação entre os retornos destes ativos e commodities agropecuárias é baixa. De fato, na maioria dos casos ela é muito próxima de zero ${ }^{2}$.

Dessa forma, pareceria vantajoso para as instituições financeiras formar carteiras de investimento combinando ativos financeiros e commodities agropecuárias, de forma a reduzir seus riscos no mercado financeiro sem afetar seu retorno. Diversos estudos [Bodie \& Rosansky (1984), Herbst \& McCormack (1986 e 1987), Elton, Gruber \& Rentzler (1990), Edwards \& Park (1996), entre outros] que serão discutidos em detalhes nos

\footnotetext{
${ }^{2}$ Cálculos realizados e não publicados pelo autor.
} 
próximos capítulos comprovam que esta estratégia pode ser adotada com sucesso em vários países.

Em um estudo nos mercados financeiros dos EUA, França, Alemanha, Japão, Suíça e Inglaterra entre 1989 e 1998, Allen (1999) mostrou que a correlação entre os retornos de contratos futuros e ações e títulos era realmente próxima de zero. Assim, o mesmo autor elaborou diversas carteiras combinando estas três classes de ativos nos mercados analisados e verificou que tal combinação aumentava a eficiência das carteiras ${ }^{3}$ em todas as situações estudadas.

No entanto, não se encontra no mercado brasileiro análises capazes de verificar a validade desta estratégia. Daí surge a questão que motivou este trabalho: será realmente proveitoso combinar ativos financeiros com commodities agropecuárias na formação de carteiras de investimento brasileiras? Em outras palavras, haveria evidências empíricas capazes de comprovar as vantagens desta combinação no Brasil?

\section{3 - Importância do problema}

Chance (1994) lembra que o mercado financeiro mundial passou por um período de grande evolução no início dos anos 80 , sendo que um dos motivos desse desenvolvimento foi a crescente popularidade dos mercados de contratos futuros. Apesar desses mercados sofrerem certa discriminação e desconfiança, o mesmo autor destaca que hoje eles são um complemento eficiente e importante para os mercados de ações e títulos.

No caso específico de commodities agrícolas, Chance (1994) cita o exemplo de um administrador de uma carteira de investimento que decide, por algum motivo qualquer, que a incorporação de soja em seu portfólio poderia elevar o retorno sem alterações significativas no risco. Porém, a compra do produto físico incorreria em diversos custos de 
armazenagem e eventual dificuldade de se encontrar um comprador para o produto no futuro. A existência de um mercado de futuros de soja resolveria esse problema, pois permitiria a esse administrador que incorporasse o produto ao seu portfólio (com as vantagens esperadas) sem a necessidade de posse física do mesmo.

Ao ressaltar a importância dos mercados futuros, o autor destaca como principal vantagem o fato de se constituírem em uma classe distinta de ativos. Para tanto, baseou-se principalmente na baixa correlação existente entre futuros e outros tipos de ativos. Essa baixa correlação, principalmente em relação às ações, significa que a incorporação de futuros a portfólios leva à diversificação do risco ${ }^{4}$ da carteira de investimentos.

O mercado de derivativos financeiros para commodities agropecuárias ainda é bastante reduzido no Brasil ${ }^{5}$. O estudo proposto por este trabalho pode contribuir para o crescimento deste mercado caso seja capaz de apresentar comprovações empíricas sobre as vantagens da utilização de commodities agropecuárias na administração de carteiras de investimento.

\section{4 - Etapas a serem seguidas}

Para realizar esse trabalho e analisar o problema supracitado, algumas etapas devem ser seguidas. Primeiramente serão definidos os conceitos de risco e retorno para, posteriormente, relacioná-los no âmbito da Teoria do Portfólio.

Uma vez apresentados os instrumentos necessários para a análise proposta, terá início a fase de apresentação e discussão dos trabalhos já realizados sobre carteiras combinando contratos futuros e outros ativos (principalmente ações e títulos). Em seguida serão apresentadas evidências empíricas sobre esta estratégia de investimento no mercado

\footnotetext{
${ }^{3}$ Allen (1999) analisa a eficiência de uma carteira por meio da sua relação retorno-risco. Carteiras com maior retorno para dado nível de risco ou com menor risco para dado patamar de retorno são consideradas mais eficientes que as demais.

${ }^{4}$ Diversificação do risco deve ser entendida como "qualquer processo que nos possibilite minimizar os efeitos do risco sobre um ativo ou uma carteira de ativos" (Securato, 1996).

${ }^{5}$ Segundo dados da Bolsa de Mercadorias e Futuros (BM\&F), os contratos futuros agrícolas representavam, até 1998 , menos de $1 \%$ do seu volume diário de negócios.
} 
financeiro brasileiro. Depois deste ponto, chega-se à etapa final do trabalho, com as discussões e conclusões sobre a viabilidade de se incluir contratos futuros agrícolas em carteiras de investimento no Brasil. 


\title{
2 - RISCO E RETORNO
}

\author{
"Nothing is more certain than the \\ prevalence of uncertainty about the \\ consequences of any economic decision ". \\ Peter J. Hammond
}

Toda decisão financeira envolve dois componentes básicos: risco e retorno. Por natureza, tais decisões implicam a escolha de oportunidades de investimento com diferentes taxas de retorno e níveis de risco, cabendo aos investidores escolher uma combinação de ambos que melhor satisfaça suas aspirações. Antes de prosseguir nesta discussão, convém definir o que se entende por risco e retorno no âmbito deste trabalho.

\section{1 - Conceito de retorno sobre um investimento}

O retorno sobre um investimento é medido como o total de ganhos ou perdas provenientes desse investimento durante um certo período de tempo. Normalmente assume-se como padrão de medida a variação percentual no valor do ativo em questão, que considera tanto o aumento no seu valor como eventuais distribuições de caixa. Matematicamente pode-se expressar o retorno sobre um investimento da seguinte maneira (Higgins, 1995):

$$
R_{t}=\frac{P_{t}+D_{t}}{P_{t-1}}-1
$$

onde

$\mathrm{R}_{\mathrm{t}}=$ taxa de retorno no período $\mathrm{t}$;

$\mathrm{Pt}=$ preço do ativo no período $\mathrm{t}$;

$\mathrm{P}_{\mathrm{t}-1}=$ preço do ativo no período t-1;

$\mathrm{D}_{\mathrm{t}}=$ distribuições de caixa recebidas pelo investimento no ativo no período $\mathrm{t}$. 
Como lembram Stern et al. ${ }^{6}$, é desejável que a distribuição de probabilidade da taxa de retorno utilizada em análises financeiras possua determinadas características, de forma a manter a coerência de algumas interpretações e facilitar o uso de métodos estatísticos de estimação. Portanto, seria pelo menos desejável que as taxas de retorno tivessem uma distribuição de probabilidade simétrica e, idealmente, que tivessem uma distribuição normal (Stern et al.). A taxa de retorno que melhor se adapta a estas características é a taxa de retorno continuamente composta, expressa por:

$$
R_{t}=\ln \left(\frac{P_{t}+D_{t}}{P_{t-1}}\right)
$$

Como destacam Bawa e Chakrin (1979), diversos autores já verificaram que os preços de ativos financeiros são bem aproximados pela distribuição lognormal. Bawa e Chakrin (1979) lembram ainda que, na verdade, os retornos de ativos financeiros não seguem exatamente uma distribuição de probabilidades normal, lognormal ou de qualquer outro tipo já estudado. O procedimento mais apropriado para verificar qual aproximação é mais adequada seria confrontar os resultados obtidos com evidências empíricas.

Ao escolher entre diversas opções de investimento não é possível saber de antemão qual delas proporcionará a melhor taxa de retorno no futuro. Assim, os investidores tomam suas decisões baseados no retorno esperado (ou taxa de retorno esperada) de cada alternativa de investimento. $\mathrm{O}$ retorno esperado de um ativo é definido como a média ponderada dos possíveis retornos, sendo as probabilidades de ocorrência de cada retorno os fatores de ponderação. Matematicamente pode-se expressar o retorno esperado de um ativo da seguinte maneira (Elton \& Gruber, 1995):

\footnotetext{
${ }^{6}$ STERN, J. M.; RIBEIRO, C. O.; DUNDER, C.; NAKANO, F. Métodos de otimização em finanças. Livrotexto do curso Métodos de Otimização e Finanças, ministrado no Instituto de Matemática e Estatística da Universidade de São Paulo. S.N.T.
} 


$$
E\left(R_{t}\right)=p_{1} R_{1}+p_{2} R_{2}+\ldots+p_{n} R_{n}=\sum_{i=1}^{n} p_{i} R_{i}
$$

onde

$E\left(R_{t}\right)=$ retorno esperado no período t;

$R_{i}=$ possíveis retornos sobre o ativo; e

$p_{i}=$ probabilidades de ocorrência associadas a cada possível retorno do ativo.

\section{2 - Conceito de risco}

O dicionário define risco como "perigo ou possibilidade de perigo". A palavra risco deriva de risicare, que, em italiano antigo, significa atrever-se, ter coragem para fazer algo. Alguns estudiosos defendem que ela se originaria do espanhol risco, que significa penhasco alto e escarpado.

Intuitivamente, o conceito de risco de um evento está relacionado à gama de possíveis resultados desse acontecimento. Quanto maior o número de possíveis resultados, maior o risco do evento, ou seja, risco está associado ao conceito de incerteza.

Neste ponto, convém destacar que risco e incerteza não são sinônimos. Knight (1921) argumentava que uma situação é considerada de risco se a aleatoriedade enfrentada por um agente econômico pode ser, objetiva ou subjetivamente, expressa em termos probabilísticos. Por outro lado, situações em que os agentes econômicos não podem (ou não conseguem) definir probabilidades caracterizam o conceito de incerteza. Em outras palavras, o risco pode ser quantificado, enquanto a incerteza não é passível de quantificação.

Em relação a investimentos financeiros, sempre houve uma grande variedade de definições utilizadas para definir risco. Na década de 50, o professor Harry Markowitz estabeleceu uma nova forma de pensar a respeito do risco ao apresentar uma medida quantitativa para 
este conceito (Markowitz, 1952). Ele definiu o risco por meio de uma medida estatística bastante popular: a variância ${ }^{7}$. Mais especificamente, Markowitz chamou de risco de um ativo a variância do retorno esperado deste ativo.

Denotando a variância do retorno de um ativo i por $\sigma_{i}^{2}$, pode-se calculá-la pela expressão:

$$
\sigma_{i}^{2}=E\left[R_{i}-E\left(R_{i}\right)\right]^{2}
$$

onde

$\mathrm{R}_{\mathrm{i}}=$ cada um dos possíveis retornos do ativo $\mathrm{i}$; e

$\mathrm{E}\left(\mathrm{R}_{\mathrm{i}}\right)=$ retorno esperado do ativo $\mathrm{i}$.

Ao medir a dispersão do retorno de um ativo em torno de seu valor esperado, a variância mostra o quanto este retorno pode se afastar daquele previsto pelo investidor. Uma variância muito elevada significa que o retorno de um ativo pode ser muito diferente daquele projetado pelo investidor. Em outras palavras, existe uma maior probabilidade (risco) de o retorno não corresponder às expectativas do investidor.

Por outro lado, uma variância pequena significa que o retorno de um ativo não deve ser muito diferente daquele estimado pelo investidor. Isso significa que a probabilidade (risco) de o retorno não corresponder à expectativa é pequena. Portanto, pode-se concluir que quanto maior a variância, maior o risco de não se obter o retorno previsto. Analogamente, quanto menor a variância do retorno de um ativo, menor o risco de não se obter o retorno previsto.

Portanto, risco deve ser entendido como "dispersão de resultados inesperados, devido a oscilações nas variáveis financeiras (...) os desvios positivos e negativos devem ser vistos como fontes de riscos" (Jorion, 1998). Isso implica a idéia de que resultados muito bons ou

\footnotetext{
${ }^{7}$ Medida de dispersão dos possíveis resultados de um experimento em torno do seu valor esperado.
} 
muito ruins devem ser analisados com cautela, pois grandes desvios em relação ao retorno previsto indicam que a análise de investimentos não foi realizada adequadamente.

Ainda sob esta ótica, Securato (1996) destaca que o risco total de um ativo pode ser subdividido em duas partes: risco sistemático (ou conjuntural) e risco residual (ou próprio). O risco sistemático consiste "no risco que os sistemas econômicos, político e social, vistos de forma ampla, impõem ao ativo" (Securato, 1996). Esta parcela do risco total reflete a reação dos diversos ativos às mudanças na economia. Evidentemente, cada ativo reage de uma forma diferente a estes movimentos, ou seja, alguns reagem bruscamente e outros mais suavemente a determinadas mudanças. Estas diferentes intensidades de reação são responsáveis pelos diferentes níveis de risco sistemático apresentados pelos diversos ativos financeiros. Segundo Securato (1996), a defesa para este tipo de risco está na escolha dos ativos "conforme a perspectiva de conjuntura ou cenário que achamos mais provável".

O risco residual consiste "no risco intrínseco ao ativo e ao subsistema ao qual pertence; é gerado por fatos que atingem diretamente o ativo em estudo ou o subsistema a que está ligado e não atingem diretamente os demais ativos e seus subsistemas" (Securato, 1996). Esta parte do risco total reflete eventos peculiares a cada ativo ou grupo de ativos. Por exemplo, uma greve de metalúrgicos tenderia a afetar imediatamente o desempenho das ações de empresas automobilísticas, mas dificilmente teria algum impacto direto sobre os preços de ações de empresas telefônicas. Esta parte do risco total pode ser eliminada por meio da diversificação científica proposta por Markowitz (1952, 1959). Para tanto, conforme será discutido em mais detalhes nos próximos capítulos, é necessário que o investidor escolha para sua carteira a maior quantidade possível de ativos com retornos que se movimentem de maneiras distintas. Logo, a técnica de diversificação científica é capaz de reduzir ou eliminar o risco por meio de seu componente residual, mas sem conseguir atingir o risco sistemático (Ross et al., 1995).

\section{3 - Comportamentos diante do risco}


Os investidores possuem diferentes preferências em relação à combinação risco-retorno de seus investimentos e, de acordo com tais preferências, podem ser classificados em três categorias (Tobin, 1958):

a) Os propensos ao risco (risk-lovers), isto é, aqueles que estariam dispostos a aceitar um menor retorno esperado para ter a chance de obter ganhos bastante elevados, sendo estes possíveis devido a um alto valor da variância. Em outras palavras, entre dois investimentos com mesmo retorno médio esperado, tais agentes escolheriam aquele de maior variância (ou, da mesma forma, de maior risco);

b) Os avessos ao risco (risk-averters), isto é, aqueles que não estariam satisfeitos em aceitar maiores níveis de risco a não ser que pudessem também obter um maior retorno esperado. Analogamente, entre dois investimentos de mesmo retorno médio esperado, estes agentes optariam por aquele de menor variância (ou, de forma equivalente, menor risco);

c) Os indiferentes ao risco, isto é, aqueles que são indiferentes entre dois investimentos de mesmo retorno médio esperado, quaisquer que sejam suas variâncias.

Em geral, a literatura financeira assume que o comportamento padrão dos investidores é somente aceitar maiores níveis de risco quando for possível obter um maior retorno esperado, ou seja, os investidores avessos ao risco são considerados como a maioria dos agentes econômicos (Simonsen, 1983).

\section{4 - Relação entre risco e retorno}


Higgins (1995) destaca que, ao se avaliar alternativas de investimentos, a questão mais adequada não é "Qual é a taxa de retorno?", mas sim "Essa taxa de retorno é suficiente para compensar o risco?". Dessa idéia deriva a relação básica entre risco e retorno: ativos cujos retornos esperados são elevados tendem a apresentar riscos também elevados.

O princípio básico desta relação é que maiores níveis de risco deveriam ser compensados por maiores taxas de retorno. Para investimentos de baixo risco, o retorno esperado tende a ser pequeno, ou seja, o investidor exigiria uma recompensa menor ao assumir um risco menor. Portanto, à medida que o risco de um ativo (ou de uma carteira) aumenta, tende também aumentar o retorno exigido pelos investidores para assumir tal risco.

Existem ainda alguns tipos de ativos que representam investimentos sem risco (ou, alternativamente, investimentos de risco zero). Tais investimentos caracterizam-se por um retorno esperado definido no momento de sua realização, ou seja, o agente econômico sabe, no momento em que realiza o investimento, qual será seu retorno e, teoricamente, não há chances desse retorno não se concretizar. Portanto, a variância do retorno deste investimento é igual a zero. Estes investimentos são conhecidos como "investimentos sem risco" e suas taxas de retorno como "taxas livres de risco" (risk-free rate). 


\section{3 - TEORIA DO PORTFÓLIO}

"Risk is no longer something to be faced; risk has become a set of opportunities open to choice".

Peter L. Bernstein

Em 1952, o então estudante da Universidade de Chicago Harry Markowitz publicou um artigo que viria a mudar os rumos do mercado financeiro. Ele demonstrou matematicamente que o investimento de todo um montante de capital em uma única aplicação financeira é uma estratégia inaceitável de administração de risco, abrindo caminho para uma teoria sobre as vantagens da diversificação de investimentos: a Teoria do Portfólio.

\section{1 - Breve histórico}

Em junho de 1952 o Journal of Finance publicou um artigo de catorze páginas intitulado Portfólio Selection. Seu autor era um estudante de 25 anos da Universidade de Chicago chamado Harry Markowitz. Nesse artigo, Markowitz analisa a administração da riqueza total de um indivíduo, ou seja, do portfólio de um investidor. O ponto principal desse estudo é que a análise de uma carteira de investimento é totalmente diferente da análise individual dos ativos que a compõem.

Bernstein (1996) destaca que, num primeiro momento, Markowitz não se preocupou com investimentos em ativos financeiros ao estudar as idéias expostas em Portfólio Selection. Naquela época seu interesse estava totalmente voltado para a programação linear, uma área de pesquisa então em surgimento. Sua preocupação era estudar formas de desenvolver modelos matemáticos capazes de minimizar custos, dado um certo nível de produção ou, analogamente, maximizar a produção mantendo os custos constantes. 
Markowitz teve sua atenção voltada para o mercado acionário ao acidentalmente encontrarse com um corretor de ações, que pediu a ele que tentasse aplicar os princípios de programação linear aos problemas enfrentados por investidores no mercado acionário.

Mas no início dos anos 50 eram poucos aqueles que conseguiam imaginar tal aplicação. Afinal de contas, a grande preocupação dos investidores à época era maximizar o retorno de seus ativos. A avaliação da performance de um investimento concentrava-se unicamente em quanto dinheiro fora ganho ou perdido com o mesmo. Não havia ainda maiores preocupações com o risco inerente a cada tipo de investimento.

Assim sendo, o trabalho pioneiro de Markowitz recebeu pouca atenção na época de sua publicação. Foi preciso que o mercado financeiro norte-americano passasse pela crise de 1973-1974 para que o conceito de avaliação de investimentos baseado unicamente no retorno passasse a ser questionado (Bernstein, 1996). As pesadas perdas de diversos fundos de investimento naquele período mostraram que os administradores de portfólios deveriam também se preocupar com o fator risco.

A partir daquele momento, investidores entenderam que os retornos sobre seus investimentos dependiam dos preços dos ativos no futuro incerto, ou seja, que havia um risco inerente a esses investimentos. Por mostrar que esse risco pode ser medido e administrado, o trabalho de Markowitz passou a ganhar maior destaque quase vinte anos depois de sua publicação.

\section{2 - Formulação da Teoria do Portfólio}

A Teoria do Portfólio trata da seleção de aplicações financeiras capazes de maximizar a utilidade esperada de um investidor, que é medida em termos de retorno esperado e risco. Através de métodos quantitativos e dados históricos, esta teoria estima valores para o retorno esperado e o risco de diversos tipos de investimento e, a partir de tais informações, 
indica como construir uma carteira condizente com a combinação risco-retorno mais apropriada para cada perfil de investidor.

Baseada nestas idéias, a Teoria do Portfólio estabelece as seguintes suposições (Alexander \& Francis, 1986):

a) os investidores buscam maximizar suas utilidades esperadas;

b) os investidores trabalham com um horizonte temporal de um período;

c) os investidores são avessos ao risco;

d) os investidores escolherão suas carteiras ótimas com base nas médias e nas variâncias dos retornos dos ativos (ou seja, retorno esperado e risco);

e) os mercados são perfeitos (custos operacionais e impostos não existem);

f) os investidores são tomadores de preços;

g) os ativos são infinitamente divisíveis de forma que podem ser comprados em partes se for necessário;

h) a soma das participações de cada ativo na carteira deve ser igual a 1;

i) a participação de cada ativo no portfólio deve ser maior ou igual a zero, ou seja, não são admitidas compras a descoberto ${ }^{8}$;

j) nenhum dos coeficientes de correlação entre os retornos dos ativos da carteira é igual a -1 ;

k) nenhum dos ativos da carteira apresenta variância do retorno igual a zero, ou seja, não se considera ativos livres de risco entre as alternativas do investidor; e

1) pelo menos dois dos $\mathrm{N}$ ativos da carteira têm retornos esperados diferentes (se todos apresentassem o mesmo retorno esperado, bastaria ao investidor escolher aquele com menor risco).

Uma das principais inovações de Markowitz foi a sugestão de uma nova regra para determinar o comportamento dos investidores. Em vez de assumir que os investidores preocupam-se apenas em maximizar o retorno esperado de seus investimentos (como supunha-se na época em que escreveu Portfólio Selection), Markowitz propôs que se

\footnotetext{
${ }^{8}$ Esta suposição é eliminada em versões posteriores do modelo.
} 
pensasse em termos de utilidade esperada. Ele argumentava que um retorno esperado de $20 \%$ poderia não ser necessariamente duas vezes melhor do que um retorno esperado de $10 \%$. Da mesma forma, um prejuízo de $20 \%$ poderia não ser duas vezes pior que um prejuízo de $10 \%$. Isso dependeria das preferências do investidor, expressas pela sua função de utilidade.

Alexander \& Francis (1986) mostram que Markowitz sugeriu que o grau de satisfação de um investidor estaria diretamente relacionado a seu nível de riqueza em determinado período de tempo. Este, por sua vez, seria uma função do nível inicial de riqueza do investidor e da taxa de retorno:

$w_{t}=w_{0}(1+R)$

onde

$w_{t}=$ riqueza do investidor em $\mathrm{t}$;

$w_{0}=$ riqueza do investidor no período $0 ; \mathrm{e}$

$R=$ taxa de retorno obtida pelo investidor entre os períodos $0 \mathrm{e} \mathrm{t}$.

Da equação (5) tem-se que:

$E\left(w_{t}\right)=E\left[w_{0}(1+R)\right]=E\left(w_{0}+w_{0} R\right)=E\left(w_{0}\right)+E\left(w_{0} R\right)=w_{0}+w_{0} E(R)$

$\mathrm{e}$

$$
\begin{aligned}
\operatorname{Var}\left(w_{t}\right) & =\operatorname{Var}\left[w_{0}(1+R)\right]=\operatorname{Var}\left(w_{0}+w_{o} R\right)=\operatorname{Var}\left(w_{o}\right)+\operatorname{Var}\left(w_{o} R\right)+2 \operatorname{Cov}\left(w_{0}, R\right)= \\
& =w_{0}^{2} \operatorname{Var}(R)=w_{0}^{2} \sigma_{R}^{2}
\end{aligned}
$$

Portanto, pode-se também assumir que, dado um determinado nível de riqueza inicial, o grau de satisfação do investidor é função da taxa de retorno de seu investimento (Alexander \& Francis, 1986). O grau de satisfação do investidor pode ser representado por sua função utilidade. Dessa forma, um investidor racional poderia maximizar a utilidade esperada do retorno de seu investimento em vez de simplesmente maximizar seu retorno esperado. 
Markowitz assume então uma função utilidade $\mathrm{U}=\mathrm{U}\left(\mathrm{w}_{\mathrm{t}}\right)$, sendo $\mathrm{w}_{\mathrm{t}}$ a riqueza de um indivíduo no período t. Considerando que $U\left(w_{t}\right)$ é uma função quadrática e expandindo-a em torno do valor esperado de $\mathrm{w}_{\mathrm{t}}\left(\overline{w_{t}}\right)$ em série de Taylor, tem-se o seguinte resultado (Alexander \& Francis, 1986):

$U=f\left(\overline{w_{t}}\right)+f^{1}\left(\overline{w_{t}}\right)\left(w_{t}-\overline{w_{t}}\right)+\frac{f^{2}\left(\overline{w_{t}}\right)\left(w_{t}-\overline{w_{t}}\right)^{2}}{2 !}+\sum_{i=3}^{\infty} \frac{f^{i}\left(\overline{w_{t}}\right)\left(w_{t}-\overline{w_{t}}\right)^{i}}{i !}$

Aplicando o operador esperança matemática na equação (8), tem-se a utilidade esperada do investidor:

$E(U)=f\left(\overline{w_{t}}\right)+f^{1}\left(\overline{w_{t}}\right) E\left(w_{t}-\overline{w_{t}}\right)+\frac{f^{2}\left(\overline{w_{t}}\right) E\left(w_{t}-\overline{w_{t}}\right)^{2}}{2 !}+\sum_{i=3}^{\infty} \frac{f^{i}\left(\overline{w_{t}}\right) E\left(w_{t}-\overline{w_{t}}\right)^{i}}{i !}$

Analisando a equação (9) termo a termo, chega-se às seguintes conclusões (Alexander \& Francis, 1986):

a) $f\left(\overline{w_{t}}\right)$ é o valor da função U em $\overline{w_{t}}=E\left(w_{t}\right)$;

b) $E\left(w_{t}-\overline{w_{t}}\right)=E\left(w_{t}\right)-\overline{w_{t}}=0 ; \mathrm{e}$

c) $E\left(w_{t}-\overline{w_{t}}\right)^{2}=E\left[w_{t}-E\left(w_{t}\right)\right]^{2}=\operatorname{Var}\left(w_{t}\right)=\sigma_{w_{t}}^{2}$.

Considera-se ainda que os termos de ordem superior a dois da equação (9) são iguais a zero. Isso é possível graças à suposição de que a função utilidade é quadrática, ou seja, seus momentos de ordem superior a dois são nulos; ou de que os retornos esperados seguem uma distribuição normal ou lognormal, o que significa que os momentos de ordem superior a dois da função utilidade podem ser expressos em termos dos dois primeiros momentos [(Alexander \& Francis, 1986); (Huang \& Litsenberg, 1988)]. Desta forma, é possível reescrever a equação (9) da seguinte maneira: 
$E(U) \cong f\left(\overline{w_{t}}\right)+\sigma_{w_{t}}^{2} \frac{f^{2}\left(\overline{w_{t}}\right)}{2}$

Substituindo a equação (1) na equação (4):

$E(U) \cong f\left[w_{0}(1+\bar{R})\right]+w_{0}^{2} \sigma_{R}^{2} \frac{f^{2}\left\lfloor w_{0}(1+\bar{R})\right]}{2}$

onde $\bar{R}=E(R)$.

Portanto, a utilidade esperada do investidor pode ser aproximada por uma função que depende apenas do retorno esperado e da variância do retorno de uma carteira. Torna-se então mais conveniente analisar as diversas carteiras em termos de retorno e risco do que maximizar a função utilidade do investidor. Pode-se assim trabalhar com uma função que relaciona apenas o retorno esperado e o risco de uma determinada carteira.

Esta função que relaciona risco e retorno esperado de uma carteira pode ser maximizada por meio da minimização do risco para um dado patamar de retorno esperado ou pela maximização do retorno esperado para um determinado nível de risco. Isso significa que a maximização da utilidade esperada pode ser aproximada por uma destas duas alternativas.

Portanto, Markowitz sugeriu que a maximização da utilidade esperada poderia ser uma melhor alternativa na análise da seleção de portfólios e mostrou que esta alternativa poderia ser aproximada pela minimização do risco para um dado patamar de retorno esperado ou pela maximização do retorno esperado dado um certo nível de risco.

\section{3 - Conceito básico da Teoria do Portfólio}

A Teoria do Portfólio assume que, ao montar uma carteira, um investidor busca minimizar o risco de seu investimento, dado um certo nível de retorno esperado que ele está disposto a 
aceitar. De forma semelhante, pode-se dizer que o investidor busca maximizar o retorno esperado de um investimento, dado um certo nível de risco. Carteiras construídas a partir destes princípios são chamadas de carteiras eficientes (Markowitz, 1959).

Em outras palavras, ele procurava encontrar uma forma de reduzir o risco de uma carteira de investimento sem alterar sua possibilidade de ganhos. A idéia básica de seu trabalho era que o risco de uma carteira de investimento poderia ser minimizado através da chamada diversificação científica de investimentos (Markowitz, 1952 e 1959). Vale lembrar que o risco pode ser minimizado, mas dificilmente eliminado. Isso ocorre porque, conforme discutido anteriormente, a diversificação pode eliminar o risco residual de uma carteira, mas ainda assim continuaria existindo seu risco sistemático (Ross et al., 1995).

A diversificação científica sugerida por Markowitz consistia em compor uma carteira de investimento com tipos diferentes de ativos, ou seja, por ativos afetados por eventos de natureza distinta. O princípio fundamental era que os comportamentos seguidos pelos retornos de cada ativo não poderiam ser iguais. Dessa forma, se um determinado evento motivasse uma redução no retorno de um ativo, os retornos dos demais ativos não seriam afetados da mesma maneira e compensariam o primeiro efeito.

Como exemplo pode-se considerar uma carteira de investimento composta por ações de empresas de cigarros e de brinquedos. Em um determinado momento, o Congresso Nacional decide proibir a venda de cigarros em bares e padarias, o que leva analistas de investimento a projetar menores retornos para as ações da indústria de cigarros. Por outro lado, não se deve esperar qualquer efeito sobre a indústria de brinquedos. Assim, o retorno desta carteira de investimento será reduzido, mas não tanto quanto seria se ela fosse composta apenas por ações da indústria tabagista.

É importante lembrar que Markowitz não utiliza a palavra "risco" em seu trabalho, substituindo-a, com o mesmo sentido, pela variância do retorno sobre um investimento. 
Para destacar a idéia de risco, ele diz que os investidores consideram a variância do retorno sobre um investimento como algo indesejável ${ }^{9}$.

Ao transformar risco e variância em sinônimos, ele também transforma o risco de um investimento em um número, ou seja, em algo mensurável. Com isso, Markowitz possibilitou a administradores de carteiras que tratassem o risco de forma tão quantitativa quanto o retorno esperado na construção de suas carteiras de investimento.

\section{4 - Retorno e risco de um portfólio}

Conforme descrito em Portfólio Selection, o risco de um ativo é dado pela variância do mesmo, ou seja:

$$
\operatorname{var}\left(R_{i}\right)=\sum_{n=1}^{N} p_{n}\left[r_{n}-E\left(R_{i}\right)\right]^{2}
$$

onde

$\mathrm{E}\left(\mathrm{R}_{\mathrm{i}}\right)=$ retorno esperado do ativo $\mathrm{i}$;

$\mathrm{r}_{\mathrm{n}}=$ enésima taxa de retorno possível;

$\mathrm{p}_{\mathrm{n}}=$ probabilidade de se verificar a taxa de retorno $\mathrm{r}_{\mathrm{n}}$;

$\mathrm{N}=$ número total de possíveis taxas de retorno.

A medida estatística sugerida para avaliar se os retornos de dois ativos se comportam de maneira distinta ao longo do tempo é a covariância entre ambos, cuja expressão matemática é dada por:

$$
\operatorname{cov}\left(R_{i}, R_{j}\right)=p_{1}\left[r_{i 1}-E\left(R_{i}\right)\right]\left[r_{j 1}-E\left(R_{j}\right)\right]+p_{2}\left[r_{i 2}-E\left(R_{i}\right)\right]\left[r_{j 2}-E\left(R_{j}\right)\right]+\ldots+p_{N}\left[r_{i N}-E\left(R_{i}\right)\right]\left[r_{j N}-E\left(R_{j}\right)\right]
$$

onde 
$\mathrm{E}\left(\mathrm{R}_{\mathrm{i}}\right)=$ retorno esperado do ativo $\mathrm{i} ;$

$E\left(R_{j}\right)=$ retorno esperado do ativo $j$;

$\mathrm{r}_{\mathrm{in}}=$ enésima taxa de retorno possível para o ativo $\mathrm{i}$;

$\mathrm{r}_{\mathrm{jn}}=\mathrm{j}$-ésima taxa de retorno possível para o ativo $\mathrm{j}$;

$\mathrm{p}_{\mathrm{n}}=$ probabilidade de se verificar a taxa de retorno $\mathrm{r}_{\mathrm{n}}$ para os ativos i e j;

$\mathrm{N}=$ número total de possíveis taxas de retorno.

Em termos práticos, a covariância indica em que grau os retornos de dois ativos variam conjuntamente. Um valor positivo da covariância entre dois ativos significa que os retornos destes tendem a mover-se na mesma direção ao longo do tempo. Quanto mais positivo este valor, maior a tendência de seus retornos moverem-se na mesma direção. Analogamente, um valor negativo da covariância significa que os retornos de dois ativos tendem a moverse em direções opostas. No âmbito da Teoria do Portfólio, são interessantes aqueles ativos que apresentam a menor covariância possível entre eles. Afinal de contas, são estes que possibilitam a prática da diversificação científica sugerida por Markowitz.

Outra medida estatística semelhante à covariância é o coeficiente de correlação, cuja representação matemática é dada por:

$$
\operatorname{cor}\left(R_{i}, R_{j}\right)=\frac{\operatorname{cov}\left(R_{i}, R_{j}\right)}{\sigma\left(R_{i}\right) \sigma\left(R_{j}\right)}
$$

onde

$\operatorname{cov}\left(R_{i}, R_{j}\right)=$ covariância entre os retornos dos ativos $i$ e $j$;

$\sigma\left(\mathrm{R}_{\mathrm{i}}\right)=$ desvio-padrão do retorno do ativo $\mathrm{i}=\sqrt{\operatorname{var}\left(R_{i}\right)}$;

$\sigma\left(\mathrm{R}_{\mathrm{j}}\right)=$ desvio-padrão do retorno do ativo $\mathrm{j}=\sqrt{\operatorname{var}\left(R_{j}\right)}$.

O coeficiente de correlação pode apresentar valores no intervalo [+1;-1]. Valores positivos representam movimentos na mesma direção, enquanto valores negativos expressam

\footnotetext{
9 "Undesirable thing", Markowitz (1952).
} 
movimentos em direções opostas. Novamente, no âmbito da Teoria do Portfólio, interessam ativos que apresentam retornos com coeficientes de correlação diferentes de 1 .

Finalmente, assim como no caso de ativos individuais, o risco de uma carteira também pode ser avaliado pela variância de seus retornos. Porém, esta não depende apenas das variâncias dos ativos que a compõem, mas também das covariâncias entre estes ativos. Matematicamente, para uma carteira composta por $\mathrm{N}$ ativos, tem-se (Elton \& Gruber, 1995):

$$
\operatorname{Var}\left(R_{p}\right)=\sum_{j=1}^{N} \operatorname{Var}\left(X_{j}\right) w_{j}^{2}+\sum_{j=1}^{N} \sum_{\substack{k=1 \\ k \neq j}}^{N} w_{j} w_{k} \operatorname{Cov}\left(X_{j}, X_{k}\right)
$$

onde

$\operatorname{var}\left(\mathrm{R}_{\mathrm{p}}\right)=$ variância do retorno da carteira;

$\mathrm{w}_{\mathrm{j}}=$ participação de cada ativo na carteira;

$\operatorname{var}\left(\mathrm{R}_{\mathrm{j}}\right)=$ variância dos retornos de cada ativo da carteira;

$\operatorname{cov}\left(\mathrm{R}_{\mathrm{j}}, \mathrm{R}_{\mathrm{k}}\right)=$ covariância entre os retornos dos ativos da carteira.

Outro conceito importante nesta discussão é o retorno esperado da carteira, cuja representação matemática é dada por (Elton \& Gruber, 1995):

$$
E\left(R_{p}\right)=w_{1} R_{1}+w_{2} R_{2}+\ldots+w_{n} R_{n}=\sum_{i=1}^{n} w_{i} R_{i}
$$

onde

$\mathrm{E}\left(\mathrm{R}_{\mathrm{p}}\right)=$ retorno esperado da carteira;

$\mathrm{R}_{1}, \mathrm{R}_{2}, \ldots, \mathrm{R}_{\mathrm{n}}=$ retornos de cada um dos ativos da carteira;

$\mathrm{w}_{1}, \mathrm{w}_{2}, \ldots, \mathrm{w}_{\mathrm{n}}=$ participações de cada ativo na carteira. 
Portanto, o retorno esperado de uma carteira é dado pela média ponderada dos retornos esperados de cada um dos ativos que a compõem.

Finalmente, pode-se expressar a estratégia de diversificação proposta por Markowitz por meio de um problema de minimização do risco, ou seja, um investidor buscaria minimizar o risco de seu investimento sujeito a um determinado nível de retorno esperado. Analogamente, pode-se expressá-la por meio de um problema de maximização do retorno esperado dado um certo nível de risco. Assim, para o caso de $\mathrm{N}$ ativos (Elton \& Gruber, 1995):

a) $\operatorname{minimizar} \quad \operatorname{Var}\left(R_{p}\right)=\sum_{j=1}^{N} \operatorname{Var}\left(X_{j}\right) w_{j}^{2}+\sum_{j=1}^{N} \sum_{\substack{k=1 \\ k \neq j}}^{N} w_{j} w_{k} \operatorname{Cov}\left(X_{j}, X_{k}\right)$

sujeito a $\quad E\left(R_{p}\right)=w_{1} R_{1}+w_{2} R_{2}+\ldots+w_{N} R_{N}=\sum_{i=1}^{N} w_{i} R_{i}=\overline{R_{p}}$

$$
\begin{aligned}
& \sum_{i=1}^{N} w_{i}=1 \\
& w_{i} \geq 0, \mathrm{i}=1, \ldots, \mathrm{N} ; \text { ou }
\end{aligned}
$$

b) $\quad$ maximizar $\quad E\left(R_{p}\right)=w_{1} R_{1}+w_{2} R_{2}+\ldots+w_{N} R_{N}=\sum_{i=1}^{N} w_{i} R_{i}$

$$
\begin{aligned}
& \text { sujeito a } \quad \begin{array}{l}
\operatorname{Var}\left(R_{p}\right)=\sum_{j=1}^{N} \operatorname{Var}\left(X_{j}\right) w_{j}^{2}+\sum_{\substack { j=1 \\
\begin{subarray}{c}{k=1 \\
k \neq j{ j = 1 \\
\begin{subarray} { c } { k = 1 \\
k \neq j } }\end{subarray}}^{N} w_{j} w_{k} \operatorname{Cov}\left(X_{j}, X_{k}\right)=\overline{\operatorname{Var}\left(R_{p}\right)} \\
\sum_{i=1}^{N} w_{i}=1 \\
w_{i} \geq 0, \mathrm{i}=1, \ldots, \mathrm{N} .
\end{array}
\end{aligned}
$$

A solução deste problema mostrará que participação cada ativo deve ter na carteira de forma a atingir o menor risco, dado um certo nível de retorno esperado (ou maior retorno esperado, dado um nível de risco).

Pode-se observar que a matemática utilizada nestes problemas é relativamente simples, o que contribuiu para que a técnica de diversificação científica proposta por Markowitz ganhasse destaque e fosse largamente adotada por investidores em vários mercados. 


\section{5 - Críticas à Teoria do Portfólio}

Apesar das idéias inovadoras, Portfólio Selection sempre foi bastante criticado em relação ao conjunto de hipóteses que o sustentam. Uma dessas críticas trata da questão da racionalidade dos investidores, visto que estes podem não ser suficientemente racionais para seguir os passos sugeridos por Markowitz ao elaborarem suas carteiras de investimento. Afinal de contas, se a intuição prevalecesse sobre a análise quantitativa no mercado financeiro, as idéias defendidas em Portfólio Selection seriam inúteis.

O próprio Markowitz tinha consciência dessa limitação, a ponto de declarar que o homem racional, assim como o unicórnio, não existe (Markowitz, 1959). Ele argumenta que, mesmo assim, o estudo do comportamento racional pode produzir alguns princípios gerais capazes de oferecer novos pontos de vista e ajudar a aperfeiçoar a capacidade de julgamento dos indivíduos.

Uma segunda crítica insiste em uma discussão até hoje em voga: será a variância a melhor medida de risco de um investimento? Os críticos insistem que, ao considerar tanto valores superiores quanto valores inferiores à média, a variância não consegue expressar adequadamente o risco de um investimento. Isso porque valores de retorno esperado acima da média deveriam ser vistos como desejados, sendo indesejados apenas aqueles inferiores à média. Mas deve-se lembrar que valores maiores ou menores que o esperado refletem problemas na estratégia adotada pelo investidor.

No entanto, Markowitz também supõe retornos com distribuições de probabilidade simétricas, ou seja, as probabilidades de observações acima da média e de observações abaixo da média são as mesmas. Portanto, a variância pode ser bem utilizada como medida de risco para estes casos. Caso as distribuições não fossem simétricas, a variância poderia não refletir toda a incerteza relativa ao portfólio. Neste caso, uma medida estatística de assimetria deveria ser usada juntamente com a variância. 
De qualquer forma, uma alternativa para solucionar tal problema seria utilizar a semivariância, que considera apenas os valores inferiores à média. No entanto, as dificuldades operacionais em calcular esta medida dificultam sua utilização como um indicador de risco.

Por fim, se um investidor acreditar que a variância não expressa adequadamente o risco de seu investimento, pode optar por outra medida de risco que ainda corrobore as idéias de Markowitz. O importante é que o risco de um ativo possa ser quantificado e inversamente associado ao seu retorno esperado. À medida que estas características forem verificadas, outras medidas de risco podem ser consideradas.

Com relação à distribuição de probabilidade dos retornos, Bernstein (1996) destaca que os retornos de alguns ativos seguem uma distribuição normal de forma tão precisa que os princípios defendidos por Markowitz podem ser um bom guia na construção de um portfólio. O próprio Markowitz, embasado em evidências empíricas que sugerem distribuições de probabilidade simétricas para retornos de ações ${ }^{10}$, preferiu não utilizar qualquer medida de assimetria.

No entanto, este ponto ainda é motivo de críticas e questionamentos até hoje. Mesmo assumindo que os retornos sigam uma distribuição normal, alguns autores [Simonsen (1983); Huang \& Litzenberg (1988)] argumentam que esta implica um conjunto de possíveis retornos esperados ilimitado inferiormente. Mesmo sabendo que um investidor pode ter prejuízos, não é possível supor que este prejuízo supere 100\%. A tentativa de contornar esse problema considerando uma distribuição lognormal também não convence estes críticos, visto que uma combinação linear de ativos com esta distribuição não possui necessariamente a mesma distribuição.

Uma outra crítica concentra-se na dificuldade em se calcular os dados solicitados pela Teoria do Portfólio: retornos esperados, variâncias e covariâncias entre cada ativo. Uma 
alternativa para estes cálculos seria considerar dados históricos e assumir que estes são uma boa aproximação para o comportamento futuro das variáveis. Porém, o uso deste tipo de dados é perigoso (Keynes, 1921). Dados históricos são influenciados por características peculiares a determinadas épocas no tempo que podem não se repetir no futuro. Se uma característica é importante em determinada época e deixa de ser em períodos subseqüentes, o comportamento de um ativo pode ser alterado a ponto de invalidar as projeções feitas com base em dados históricos.

Finalmente, a forma da função utilidade esperada apresentada por Markowitz também tem sido contestada. A função quadrática escolhida por ele é conveniente por restringir a análise aos dois primeiros momentos da distribuição ${ }^{11}$, ou seja, à média e à variância. Quando os retornos esperados e as variâncias são finitos, este tipo de função é suficiente para descrever a seleção de investimentos em termos da média e da variância dos retornos.

O problema está nas implicações do uso de uma função quadrática. Considerando este tipo de função, tem-se que a utilidade do retorno passa a decrescer quando o retorno esperado supera o ponto de saciedade do investidor (ou seja, o ponto de máximo da parábola que representa a função), ferindo o axioma da não saciedade da teoria da utilidade. Este inconveniente poderia ser superado admitindo-se que todos os valores possíveis de retorno esperado situam-se aquém do ponto de saciedade do investidor.

A utilização de uma função utilidade quadrática também implica que a aversão absoluta ao risco do investidor torna-se crescente em relação ao retorno. Como bem observa Simonsen (1983), este é um comportamento pouco usual e significa que os ativos financeiros são bens inferiores.

Uma forma de resolver esse problema seria considerar qualquer tipo de função utilidade e supor que os retornos dos ativos apresentam uma distribuição de probabilidade normal ou

\footnotetext{
${ }^{10}$ Deve-se lembrar que Markowitz desenvolveu seu trabalho inicial (e, conseqüentemente, o conceito de risco) pensando apenas em investimentos em ações.
} 
lognormal, o que limitaria a análise aos seus dois primeiros momentos. No entanto, conforme explicado anteriormente, a suposição destas distribuições também é passível de contestação.

Portanto, pode-se concluir que a Teoria do Portfólio não apresenta um algoritmo definitivo e incontestável para a seleção de investimentos. Diversos problemas têm sido levantados desde sua elaboração, sendo que alguns podem ser contornados sem maiores dificuldades, enquanto outros seguem até hoje sem solução. Mesmo assim esta teoria continua sendo bastante utilizada devido a sua relativa simplicidade e aos satisfatórios resultados empíricos obtidos.

\section{6 - Avaliação do desempenho de uma carteira: o Índice de Sharpe}

A avaliação do desempenho de uma carteira de investimento é muito importante no mercado financeiro na medida em que sinaliza aos investidores a capacidade de um administrador de carteiras proporcionar melhores combinações de retorno e risco. Em outras palavras, o objetivo da avaliação de desempenho é avaliar a capacidade de o administrador adicionar valor a uma carteira.

Existem basicamente quatro categorias de avaliação de carteiras de investimento:

a) medidas de retorno, que simplesmente avaliam a taxa de retorno da carteira em um determinado período de tempo;

b) medidas de risco, que se limitam a representar o nível de risco da carteira;

c) medidas de seleção, que oferecem ao investidor subsídios para escolher o ativo mais adequado para sua carteira; e

d) medidas de comparação, que permitem avaliar o desempenho do administrador ao comparar a carteira por ele administrada com algum benchmark ${ }^{12}$.

\footnotetext{
${ }^{11}$ As derivadas de ordem três ou superiores são iguais a zero para funções quadráticas (Huang \& Litzemberger, 1988).
} 
Cada uma destas medidas deve ser utilizada dentro de determinados contextos e, portanto, deve-se analisar muito bem qual o objetivo da análise de desempenho antes de determinar a medida que será utilizada.

As medidas de retorno e de risco devem ser utilizadas com cuidado, pois ambas consideram apenas um parâmetro do processo de decisão de investimento. Uma medida de retorno com resultado bastante elevado poderia ser um indicador de que determinado ativo tende a oferecer elevados retornos, mas nada diz sobre o nível de risco incorrido para se atingir tal retorno. Raciocínio semelhante pode ser feito em relação às medidas de risco.

As medidas de seleção oferecem indicadores para que os investidores possam escolher, de acordo com suas preferências, os ativos mais adequados para sua carteira. Estas medidas não trazem indicações de retorno e risco em termos absolutos, mas sim de relações entre ambas.

As medidas de comparação preocupam-se em avaliar o desempenho de um ativo ou de uma carteira de investimento em relação a um determinado benchmark. Portanto, estas medidas se baseiam em comparações com parâmetros preestabelecidos pelos investidores.

Uma das medidas mais utilizadas na avaliação de investimentos é o Índice de Sharpe (IS), uma medida de seleção. Este indicador mede o retorno de um ativo acima da taxa livre de risco dividido pelo seu desvio-padrão, ou seja:

$$
I S=\frac{E\left(R_{i}\right)-R_{F}}{\sigma_{i}}
$$

onde

$E\left(R_{i}\right)$ é o retorno esperado do ativo $\mathrm{i}$;

$\mathrm{R}_{\mathrm{F}}$ é a taxa livre de risco; e

\footnotetext{
${ }^{12}$ Aplicação disponível no mercado que representa um nível de retorno desejado e um patamar de risco aceito pelo investidor.
} 
$\sigma_{i}$ é o desvio-padrão do retorno (risco) do ativo i.

Baseando-se no trabalho de Tobin (1958), Sharpe (1966) partiu da idéia de que o desempenho de uma carteira de investimentos pode ser descrito por dois parâmetros: seu retorno esperado e o desvio-padrão deste retorno. Assumiu-se que todos os administradores de carteiras poderiam aplicar seus recursos a uma determinada taxa de juros livre de risco e tomar recursos emprestados a esta mesma taxa e que existiriam duas alternativas de investimento: um ativo livre de risco e um outro ativo arriscado. $\mathrm{O}$ retorno de uma carteira formada por estes dois ativos seria dado por:

$R_{P}=x_{f} r_{f}+x_{A} r_{A}$

onde

$R_{P}=$ retorno da carteira;

$x_{f}=$ participação do ativo livre de risco na carteira;

$r_{f}=$ taxa de retorno do ativo livre de risco;

$x_{A}=$ participação do ativo arriscado na carteira; e

$r_{A}=$ taxa de retorno do ativo arriscado.

Aplicando o operador esperança matemática na equação (20), tem-se:

$E\left(R_{P}\right)=E\left(x_{f} r_{f}\right)+E\left(x_{A} r_{A}\right)=x_{f} r_{f}+x_{A} E\left(r_{A}\right)$

Isolando a variável $x_{A}$ na equação (21), tem-se:

$x_{A}=\frac{E\left(R_{P}\right)-x_{f} r_{f}}{E\left(r_{A}\right)}$

Tomando agora a variância do retorno da carteira apresentado na equação (20), tem-se: 


$$
\begin{gathered}
\operatorname{Var}\left(R_{P}\right)=\operatorname{Var}\left(x_{f} r_{f}+x_{A} r_{A}\right)=\operatorname{Var}\left(x_{f} r_{f}\right)+\operatorname{Var}\left(x_{A} r_{A}\right)+2 \operatorname{Cov}\left(x_{f} r_{f}, x_{A} r_{A}\right)= \\
=x_{f}^{2} \operatorname{Var}\left(r_{f}\right)+x_{A}^{2} \operatorname{Var}\left(r_{A}\right)+2 x_{f} x_{A} \operatorname{Cov}\left(r_{f}, r_{A}\right)
\end{gathered}
$$

Como a variância da taxa livre de risco e a covariância entre esta taxa e o retorno do ativo arriscado são iguais a zero, a equação (23) pode ser reescrita como:

$\operatorname{Var}\left(R_{P}\right)=x_{A}^{2} \operatorname{Var}\left(r_{A}\right)$

Tomando a raiz quadrada da equação (24), tem-se o desvio-padrão do retorno da carteira:

$\sigma_{P}=\sqrt{\operatorname{Var}\left(R_{P}\right)}=x_{A} \sigma_{A}$

onde

$\sigma_{P}=$ desvio-padrão do retorno do ativo livre de risco; e

$\sigma_{A}=$ desvio-padrão do retorno do ativo arriscado.

Isolando a variável $x_{A}$ na equação (25), tem-se:

$x_{A}=\frac{\sigma_{P}}{\sigma_{A}}$

Igualando os valores de $x_{A}$ das equações (22) e (26):

$$
\begin{aligned}
& \frac{E\left(R_{P}\right)-r_{f}}{E\left(R_{A}\right)-r_{f}}=\frac{\sigma_{P}}{\sigma_{A}} \\
& E\left(R_{P}\right)=r_{f}+\left[\frac{E\left(R_{A}\right)-r_{f}}{\sigma_{A}}\right] \sigma_{P}
\end{aligned}
$$


De acordo com as idéias de Tobin (1958), a equação (27) representa o locus de oportunidade de um investidor cuja carteira é composta por um ativo livre de risco e um ativo arriscado. Tobin (1958) explica que a equação (27) mostra que um valor alto de $\sigma_{P}$ pode trazer maiores oportunidades de ganhos $\left[E\left(R_{P}\right)\right]$ para o investidor às custas de uma maior possibilidade de perdas. Por outro lado, um valor mais baixo de $\sigma_{P}$ protege o investidor contra grandes possibilidades de perdas, mas também oferece menores possibilidades de ganhos mais altos. Estas relações podem ser representadas no espaço retorno esperado x risco, o que é mostrado na figura 3.1.

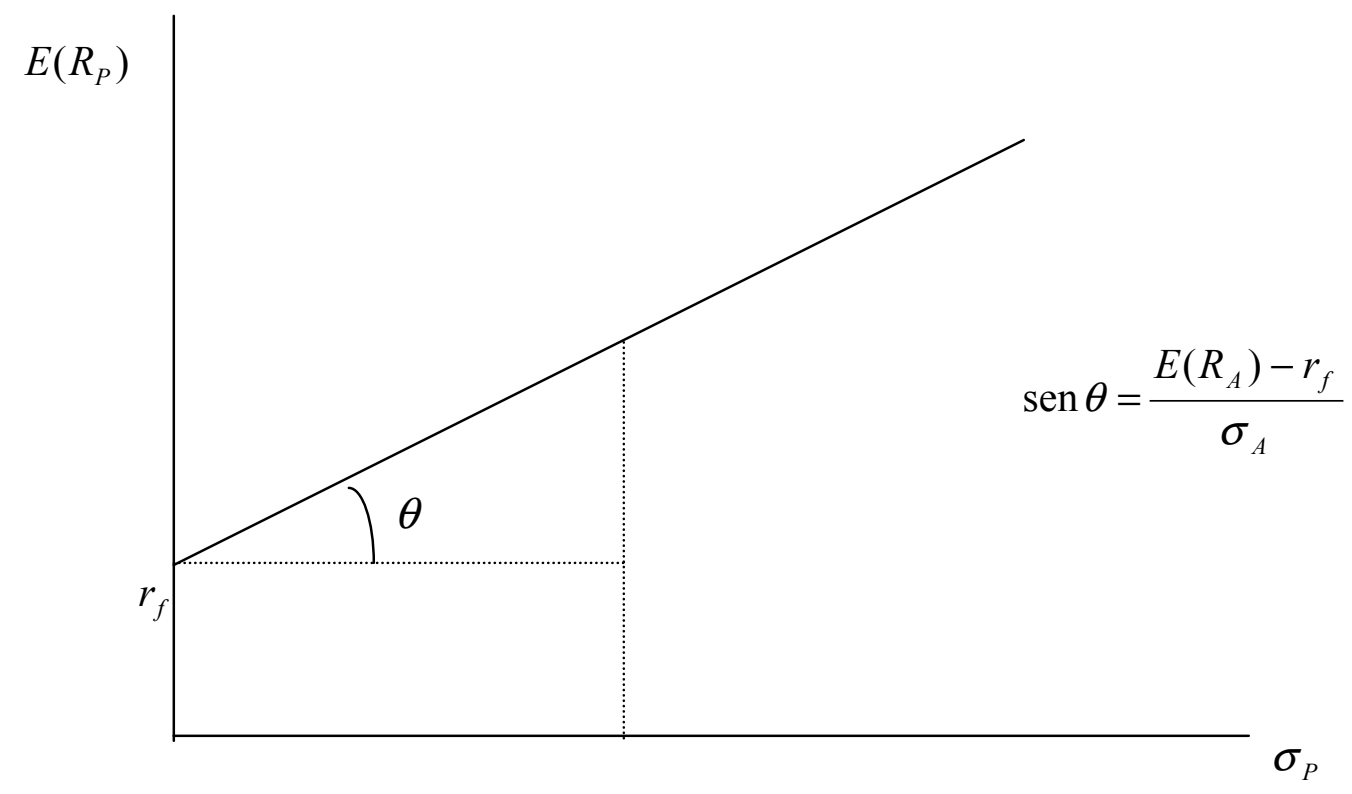

Figura 3.1 - Representação de uma carteira no espaço retorno x risco

Conforme discutido por Sharpe (1966), pode-se observar, na figura 3.1 e na equação (27), que o investidor que não quiser assumir risco algum deverá contentar-se com um retorno igual à taxa livre de risco. Se este investidor estiver disposto a assumir riscos, terá maiores oportunidades de obter retornos maiores à medida que assumir riscos mais elevados. Esta relação de proporcionalidade entre retorno e risco é dada pelo coeficiente angular da reta, ou seja, quanto maior for este número, proporcionalmente maior será o retorno esperado da carteira a cada nível de risco assumido. 
Para cada carteira de investimentos existente, será possível representá-la por uma reta definida conforme a equação (27). A figura 3.2 mostra a representação de diversas carteiras no espaço retorno esperado x risco e pode-se perceber que aquelas de maior coeficiente angular oferecem nível mais elevado de retorno esperado a cada patamar de risco, ou ainda, oferecem um nível menor de risco a cada patamar de retorno esperado. Portanto, um investidor poderia escolher a carteira de investimentos que oferecesse um nível maior de retorno proporcionalmente ao risco com base neste coeficiente angular. Aquela carteira que apresentasse maior coeficiente angular deveria ser a escolhida pelo investidor (Sharpe, 1966). Este coeficiente passou a ser conhecido na literatura de finanças como Índice de Sharpe.

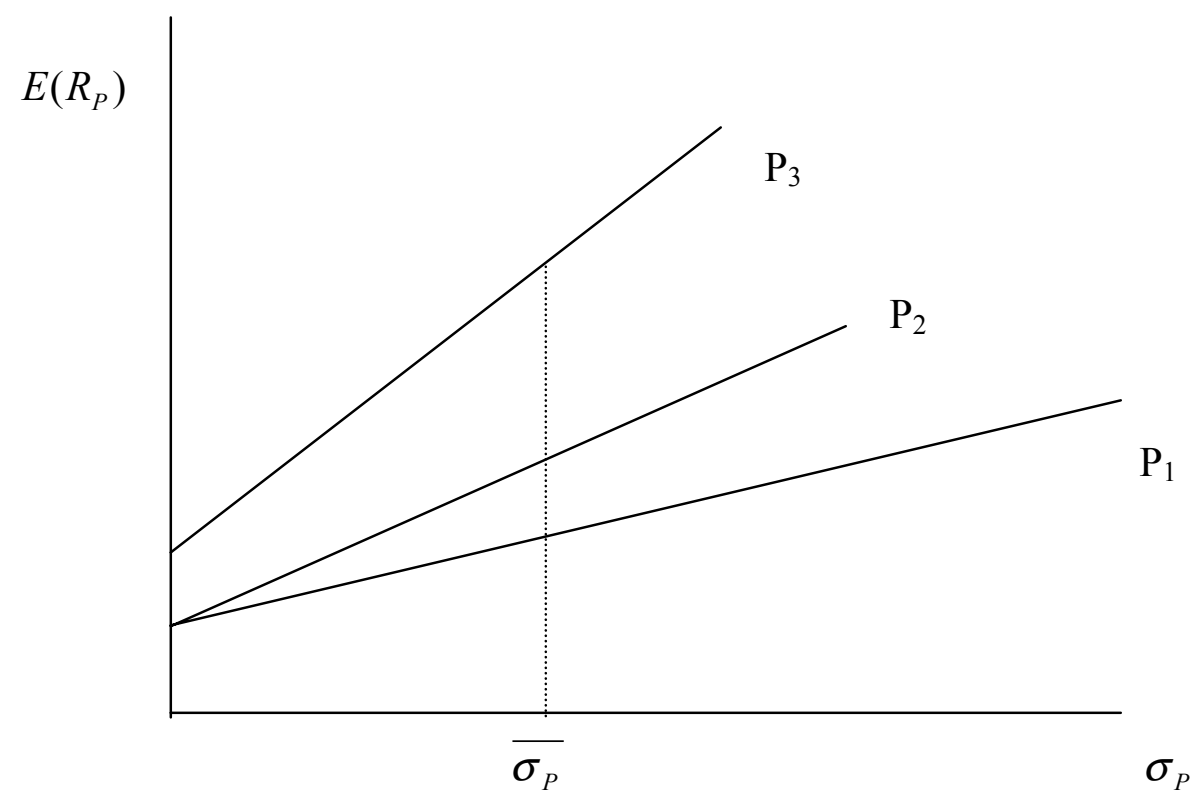

Figura 3.2 - Representação de três carteiras no espaço retorno x risco

O Índice de Sharpe avalia a decisão de investimento sob o ponto de vista de um investidor, o que explica a utilização do desvio-padrão do retorno como medida de risco. Se um investidor está buscando uma carteira para aplicar uma parcela de sua riqueza, ele estará preocupado com o risco total desta carteira. Portanto, o Índice de Sharpe mede o retorno obtido por unidade de risco assumida pelo investidor. 
Um Índice de Sharpe positivo significa que determinado ativo ofereceu um prêmio pelo risco assumido, enquanto um índice negativo mostra que dado ativo ofereceu um prêmio negativo pelo risco assumido. Se o índice for maior que 1, têm-se que o prêmio oferecido foi proporcionalmente maior que o risco assumido. Para valores entre 0 e 1 , o índice indica que o prêmio oferecido foi proporcionalmente menor que o risco assumido. Dessa forma, ativos com valores mais elevados para o Índice de Sharpe são preferíveis àqueles com valores menores, pois os primeiros estariam oferecendo maior retorno por unidade de risco assumida.

Apesar de ser largamente utilizado, o Índice de Sharpe apresenta alguns problemas. Pode-se observar que o Índice de Sharpe depende do período de tempo sobre o qual foi calculado. Os valores de $\mathrm{E}\left(\mathrm{R}_{\mathrm{i}}\right)$ e $\sigma_{i}$ são geralmente calculados com base em dados históricos de retornos e, portanto, tendem a apresentar resultados diversos de acordo com o período de tempo escolhido. Logo, o Índice de Sharpe é temporalmente dependente.

Um segundo problema ocorre quando o Índice de Sharpe apresenta valores menores que zero, ou seja, quando o prêmio de risco é negativo. Neste caso, o índice pode levar a conclusões erradas na escolha entre alternativas de investimento. Para exemplificar esta situação, pode-se considerar dois ativos que apresentem prêmios de risco iguais entre si de $-0,2 \%$ e desvio-padrão dos retornos de, respectivamente, $0,3 \%$ e $0,1 \%$. O primeiro ativo apresenta um Índice de Sharpe igual a -0,66, enquanto o do segundo ativo é de -2 . Pelo critério estabelecido anteriormente, o ativo escolhido pelo investidor deveria ser o primeiro, que apresenta maior Índice de Sharpe. Porém, é fácil perceber que o ativo escolhido deveria ser o segundo, pois ele apresenta retorno esperado igual ao do primeiro $(-0,2 \%)$, com um desvio-padrão menor $(0,1 \%)$.

Desta forma, Duarte (1998) lembra que, ao comparar-se ativos por meio do Índice de Sharpe, intervalos de confiança ou testes estatísticos devem ser preferíveis a estimativas pontuais. Uma estimativa pontual do índice em relação a um determinado ativo pode ser 
numericamente superior à estimativa em relação a outro ativo, mas isso não garante que haja uma diferença estatisticamente significante entre ambos. 


\title{
4 - REVISÃO DE LITERATURA
}

\author{
"A rule of behavior which does not imply the \\ superiority of diversification must be rejected both \\ as a hypothesis and as a maxim”. \\ Harry M. Markowitz
}

\section{1 - Considerações iniciais}

Diversos trabalhos têm tratado da diversificação de carteiras por meio da combinação de contratos futuros e outros ativos, principalmente ações e títulos. Praticamente todos eles foram realizados para o mercado financeiro norte-americano e vários referem-se ao que se chama de managed futures.

Managed futures são carteiras de investimento que operam contratos futuros e a termo de commodities físicas (agrícolas ou industriais) e outros ativos (como moedas, taxas de juros, títulos e ações). Para efeito de simplificação e sem risco de prejudicar a discussão, será utilizado o termo "contratos futuros" no lugar de managed futures no restante deste capítulo.

Como explicado anteriormente, deve-se ter em mente que muitos trabalhos referem-se a contratos futuros em geral, ou seja, normalmente não há menções específicas a commodities agrícolas nas estratégias de investimento analisadas.

A grande maioria dos trabalhos já realizados sobre esse assunto chega a conclusões muito semelhantes sobre a inclusão de contratos futuros em carteiras, que podem ser resumidas pelo artigo de Schneeweis e Spurgin (1997): 
(a) a correlação existente entre os retornos de contratos futuros e ações é aproximadamente nula, sendo que tende a ser negativa quando o mercado acionário está em baixa e positiva quando o mercado acionário está em alta;

(b) as vantagens obtidas com a inclusão de contratos futuros em carteiras também podem ser alcançadas com outros tipos de investimento; e

(c) a despeito das vantagens verificadas, muitos investidores ainda relutam em adotar estratégias que incluam contratos futuros em suas carteiras.

A seguir serão apresentados e discutidos os diversos trabalhos encontrados sobre o tema e as características citadas anteriormente poderão ser observadas e compreendidas de forma mais clara.

\section{2 - Apresentação dos trabalhos já realizados sobre o assunto}

Um dos primeiros estudos a ganhar destaque foi escrito em 1980 por Zvi Bodie e Victor I. Rosansky (Bodie \& Rosansky, 1984). Nesse trabalho, os retornos obtidos nos mercados futuros de commodities foram comparados com os retornos obtidos nos mercados de ações e de títulos públicos nos EUA. Mostrou-se que os retornos médios das carteiras de ações e de commodities foram praticamente os mesmos no período analisado, destacando ainda a proximidade entre os desvios-padrões dos retornos de ambas as carteiras (Tabela 1).

Tabela 1. Risco e retorno para algumas alternativas de investimento no período 1950-1976.

\begin{tabular}{lcc}
\hline \multicolumn{1}{c}{ Ativo } & Taxa média de retorno anual & $\begin{array}{c}\text { Desvio-padrão médio dos retornos } \\
\text { anuais (risco) }\end{array}$ \\
\hline S\&P500 & $13,05 \%$ & $18,95 \%$ \\
Commodities & $13,83 \%$ & $22,43 \%$ \\
Títulos de longo prazo & $2,84 \%$ & $6,53 \%$ \\
T-Bills & $3,63 \%$ & $1,95 \%$ \\
\hline
\end{tabular}

Fonte: Bodie \& Rosansky (1984). Elaborada pelo autor.

Bodie \& Rosansky (1984) utilizaram informações sobre 23 commodities $^{13}$ negociadas em mercados futuros dos EUA entre dezembro de 1949 e dezembro de 1976 (ou, como os

\footnotetext{
${ }^{13}$ Esse trabalho não faz distinção entre commodities agrícolas e commodities industriais.
} 
próprios autores preferem dizer, entre 1950 e 1976) para calcular a taxa de retorno de cada uma delas e também de uma carteira composta por todas elas (distribuídas igualmente). $\mathrm{O}$ mercado acionário foi representado pelo índice Standard \& Poor's 500 (S\&P500) ${ }^{14}$, enquanto os títulos públicos escolhidos foram os títulos de longo prazo do governo dos EUA e os Treasury Bills (T-Bills) ${ }^{15}$.

Por outro lado, ao analisar os dados anuais, observou-se que, em geral, as commodities apresentaram taxas de retorno bastante elevadas nos anos em que as ações registravam taxas de retorno bastante modestas. Da mesma forma, as ações tendiam a atingir taxas de retorno elevadas quando as commodities mostravam taxas de retorno baixas, sendo tal comportamento justificado através da correlação negativa existente entre esses dois ativos (Tabela 2).

Tabela 2. Matriz de correlações das taxas anuais de retorno para o período 1950-1976.

\begin{tabular}{lcccc}
\hline & S\&P500 & Commodities & $\begin{array}{c}\text { Títulos de longo } \\
\text { prazo }\end{array}$ & T-Bills \\
\hline S\&P500 & $+1,00$ & $-0,24$ & $-0,10$ & $-0,57$ \\
Commodities & $-0,24$ & $+1,00$ & $-0,16$ & $+0,34$ \\
Títulos de longo prazo & $-0,10$ & $-0,16$ & $+1,00$ & $+0,20$ \\
T-Bills & $-0,57$ & $+0,34$ & $+0,20$ & $+1,00$ \\
\hline
\end{tabular}

Fonte: Bodie \& Rosansky (1984). Elaborada pelo autor.

Como os retornos obtidos por ações e commodities foram praticamente os mesmos (Tabela 1) e suas correlações são negativas (Tabela 2), os autores sugerem que um investidor poderia ter reduzido seu risco sem afetar sua taxa de retorno no período analisado por meio da combinação de ações e commodities em uma mesma carteira. Algumas opções de carteiras combinando ambos os ativos foram então elaboradas para comprovar essa hipótese (Tabela 3).

\footnotetext{
${ }^{14}$ O Standard \& Poor's 500 é um índice que mede o comportamento dos preços de uma cesta composta por 500 ações do mercado norte-americano.

${ }^{15}$ Títulos de curto prazo do Tesouro dos EUA.
} 
Tabela 3. Risco e retorno para uma carteira composta por ações e commodities no período 19501976.

\begin{tabular}{cccc}
\hline $\begin{array}{c}\text { Participação de } \\
\text { ações }\end{array}$ & $\begin{array}{c}\text { Participação de } \\
\text { commodities }\end{array}$ & $\begin{array}{c}\text { Taxa de retorno } \\
\text { média }\end{array}$ & $\begin{array}{c}\text { Desvio padrão médio dos } \\
\text { retornos (risco) }\end{array}$ \\
\hline $100 \%$ & $0 \%$ & $13,05 \%$ & $18,95 \%$ \\
$80 \%$ & $20 \%$ & $13,21 \%$ & $14,74 \%$ \\
$60 \%$ & $40 \%$ & $13,36 \%$ & $12,68 \%$ \\
$40 \%$ & $60 \%$ & $13,52 \%$ & $13,77 \%$ \\
$20 \%$ & $80 \%$ & $13,67 \%$ & $17,43 \%$ \\
$0 \%$ & $100 \%$ & $13,83 \%$ & $22,43 \%$ \\
\hline
\end{tabular}

Fonte: Bodie \& Rosansky (1984). Elaborada pelo autor.

Pelos dados apresentados pôde-se concluir que seria possível reduzir o risco de uma carteira ao combinar ativos cujos retornos fossem negativamente correlacionados. Tal estratégia permitiu uma expressiva redução do risco do investidor sem alterar significativamente seu retorno (figura 1).

Figura 1. Risco e retorno para uma carteira composta por ações e commodities no período 1950-1976.

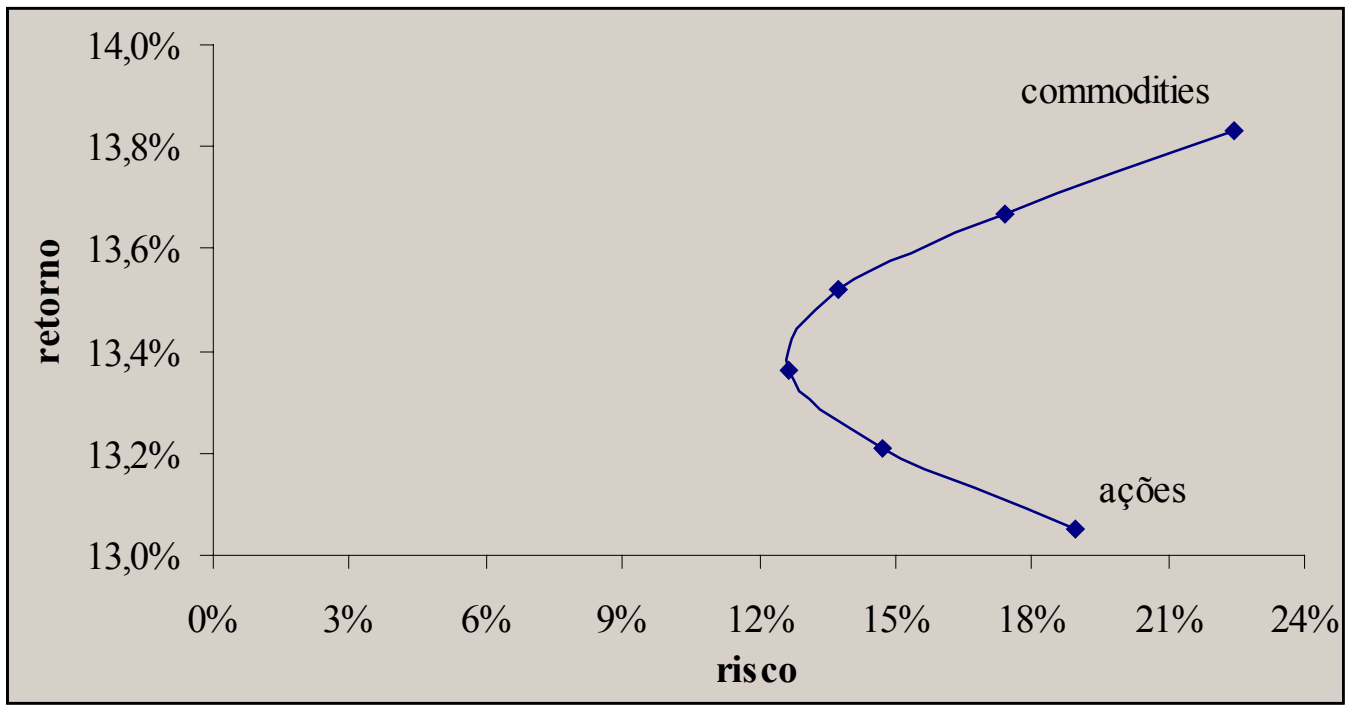

Fonte: Bodie \& Rosansky (1984). Elaborada pelo autor.

Em um artigo escrito em 1983, Lintner (1997) analisou o desempenho de carteiras sugeridas por $15 \mathrm{CTAs}^{16}$ e 8 fundos de commodities (baseados em contratos futuros) no

\footnotetext{
${ }^{16}$ Commodity trader advisors (CTA) são pessoas que aconselham ou tomam decisões para investidores a respeito de negociações em mercados futuros. No caso, a análise do desempenho de um CTA é feita com base em suas recomendações de investimento.
} 
período de julho de 1979 a dezembro de 1982. Foram comparadas as performances dos CTAs e dos fundos com outros três ativos: ações ${ }^{17}$, títulos privados ${ }^{18}$ e T-Bills. O autor calculou os coeficientes de correlação entre os retornos dos ativos analisados a fim de verificar a possibilidade de utilizá-los para diversificar uma carteira de investimento.

Os resultados encontrados mostraram que quase todos os coeficientes são próximos de zero (Tabela 4), o que levou o autor a concluir que a inclusão de contratos futuros em carteiras compostas por ações e títulos poderia aumentar sua eficiência. Ao testar esta hipótese, comprovou-se que carteiras combinando contratos futuros e ações / títulos dominam outras combinações de carteiras compostas apenas por ações ou por ações e títulos.

Tabela 4. Correlações entre os retornos dos fundos de commodities e CTAs com os de outros ativos no período de julho de 1979 a dezembro de 1982.

\begin{tabular}{lcc}
\hline & Fundos de commodities & CTAs \\
\hline Ações & $+0,234$ & $+0,059$ \\
Títulos & $+0,151$ & $+0,148$ \\
Carteira ações/títulos & $-0,024$ & $+0,116$ \\
\hline
\end{tabular}

Fonte: Lintner (1997). Elaborada pelo autor.

Em seguida, o autor define uma regra para avaliar se contratos futuros devem ou não ser incluídos em carteiras de ações e/ou títulos. Segundo ele, estes contratos somente devem ser incluídos em tais carteiras se forem capazes de aumentar sua relação retorno-risco. Para tanto, seria necessário que a razão de Sharpe dos contratos futuros fosse maior que o produto entre razão de Sharpe da carteira de ações e/ou títulos e o coeficiente de correlação entre os retornos dos contratos futuros e da carteira.

$$
S_{F}>S_{P} \rho_{F, P}
$$

onde:

$\mathrm{S}_{\mathrm{F}}$ é a razão de Sharpe dos contratos futuros;

\footnotetext{
${ }^{17}$ Representadas por uma carteira ponderada de ações da New York Stock Exchange (NYSE) e da American Stock Exchange (Amex).

${ }^{18}$ Representados por um índice de títulos da corretora Salomon Brothers, o Salomon Brothers High-Grade Long-Term Corporate Bond Index.
} 
SP é a razão de Sharpe da carteira de ações e /ou títulos; e

$\rho_{F, P}$ é o coeficiente de correlação entre os retornos dos contratos futuros e da carteira de ações e/ou títulos.

Deve-se destacar que esta condição não se baseia em um modelo de precificação de ativos de equilíbrio e é relevante apenas para carteiras predeterminadas, que podem ou não ser ótimas ou eficientes. Isso significa que esta relação apenas verifica se a inclusão de contratos futuros pode melhorar a relação retorno-risco da carteira, independentemente de haver outras possibilidades de se alcançar o mesmo objetivo.

Vale observar que, caso o coeficiente de correlação seja igual a zero (como muitos estudos sugerem), a regra apresentada por Lintner (citada anteriormente) resume-se à razão de Sharpe dos contratos futuros ser positiva. Ou ainda, que o retorno esperado destes contratos seja superior à taxa livre de risco.

$$
\frac{R_{F}-r}{\sigma_{F}}>0
$$

onde:

$\mathrm{R}_{\mathrm{F}}$ é o retorno dos contratos futuros;

r é a taxa de juros livre de risco; e

$\sigma_{F}$ é o desvio-padrão dos retornos dos contratos futuros.

Irwin e Brorsen chegaram às mesmas conclusões a partir da análise de 84 fundos de commodities norte-americanos no período de janeiro de 1975 a maio de 1984 (Chance, 1994). Foram calculadas as correlações existentes entre os retornos trimestrais desses fundos com os de ações, títulos privados e T-Bills (Tabela 5) e concluiu-se que a inclusão de commodities a uma carteira de investimentos composta por ações, títulos privados e títulos públicos pode aumentar sua eficiência. 
Tabela 5. Correlação entre os retornos de ativos no período de janeiro de 1975 a maio de 1984.

\begin{tabular}{lcccc}
\hline & Commodities & Ações & Títulos privados & T-Bills \\
\hline Commodities & $+1,00$ & $-0,633$ & $-0,529$ & $-0,367$ \\
Ações & $-0,633$ & $+1,00$ & n.d. & n.d. \\
Títulos privados & $-0,529$ & n.d. & $+1,00$ & n.d. \\
T-Bills & $-0,367$ & n.d. & n.d. & $+1,00$ \\
\hline
\end{tabular}

Fonte: Irwin e Brorsen (Chance, 1994). Elaborada pelo autor.

Uma abordagem diferente foi utilizada por Lee et al. (1985), que examinaram a questão da diversificação científica por meio de testes estatísticos. Para tanto, utilizou-se os retornos diários do S\&P500 e do CRB Index ${ }^{19}$ no período de 1978 a 1981 e foi testada a existência de algum tipo de relação entre os índices de ações e commodities.

Para tanto, os autores fizeram a regressão dos retornos das commodities contra os retornos das ações ${ }^{20}$, de forma a verificar se havia risco sistemático entre ambos. Quanto maior o risco sistemático existente entre os dois índices, menor a capacidade de redução do risco de uma carteira por meio da combinação de ambos os ativos. Os resultados mostraram que valores de risco sistemático diferentes de zero não são estatisticamente significativos. Portanto, verificou-se que não há indícios de existência de risco sistemático entre os dois ativos e, assim, é possível diversificar uma carteira por meio da combinação de ambos ${ }^{21}$.

Herbst e McCormack (1986) também utilizaram um método um pouco diferente dos demais para chegar à mesma conclusão. $\mathrm{O}$ objetivo era testar se a inclusão de futuros em carteiras de ações escolhidas aleatoriamente poderia deslocar a fronteira eficiente desta carteira para cima e para a esquerda, ou seja, aumentar o retorno esperado para um mesmo nível de risco ou reduzir o risco para um mesmo patamar de retorno esperado. Com isso, o investidor que adotasse tal estratégia poderia obter uma melhor relação risco-retorno e atingir uma curva de indiferença superior.

\footnotetext{
${ }^{19}$ O Commodity Research Bureau Index (CRB Index) é um índice que mede o comportamento dos preços de uma cesta de commodities.

${ }^{20} \mathrm{R}_{\mathrm{CRB}}=a+b \mathrm{R}_{\mathrm{S} \& \mathrm{P}}+e$, onde $a$ é o termo constante da regressão, $b$ é o coeficiente utilizado para avaliar a presença de risco sistemático (quanto maior o valor de $b$, maior o risco sistemático) e $e$ mede o erro aleatório.

${ }^{21}$ Deve-se ressaltar que foram realizados apenas testes de dependência linear, ou seja, não foi avaliada a possibilidade de haver algum tipo de dependência não linear entre as variáveis.
} 
Para tanto, foram formadas carteiras com 8, 10, 12, 14, 16 e 32 ações selecionadas aleatoriamente. Utilizou-se o algoritmo de Markowitz para formar estas carteiras e foram considerados 48 dados mensais (não foi especificado o período exato deste estudo). O passo seguinte foi escolher oito contratos futuros por meio da análise de componentes principais de forma que o grau de correlação entre eles fosse baixo.

Os autores então passaram a incluir contratos futuros no lugar de uma ação (escolhida aleatoriamente) da carteira. Este processo foi repetido por mais sete vezes até que todos os contratos futuros estivessem incluídos nas carteiras. A cada substituição, as ponderações de cada ativo eram recalculadas de forma a manter o risco da carteira em seu nível mínimo. Os resultados desse estudo mostraram que tal substituição aumentava continuamente a eficiência das carteiras até o ponto em que contratos futuros representavam $70 \%$ das mesmas.

Em um estudo posterior, Herbst e McCormack (1987) basearam-se no mesmo objetivo e utilizaram a mesma metodologia, mas desta vez em carteiras com 10 e 15 ações no período de janeiro de 1980 a novembro de 1984 (58 observações). Além disso, os autores consideraram um outro objetivo: analisar se a inclusão de contratos futuros em carteiras de ações seria capaz de deslocar sua fronteira eficiente totalmente ou apenas parcialmente.

As conclusões sobre as vantagens de incluir contratos futuros em carteiras de ações foram semelhantes às de estudos anteriores, mas a eficiência das carteiras aumentava apenas até o ponto em que os contratos futuros correspondiam de $25 \%$ a $30 \%$ das mesmas. Isso significa que apenas até este ponto foi possível verificar o deslocamento completo da fronteira eficiente das carteiras.

Voltando aos métodos mais "tradicionais", Baratz e Eresian realizaram dois estudos, um em 1986 e outro em 1990 (Chance, 1994). Em ambos analisou-se os retornos mensais de contratos futuros de commodities, de um índice de ações à vista (S\&P500) e de uma carteira de títulos públicos (todos com prazo mínimo de dez anos). O primeiro estudo 
abrangia o período de 1980 a 1985 e registrou as seguintes correlações: -0,036 entre contratos futuros e o S\&P500 e -0,101 entre contratos futuros e títulos. Já o segundo estudo abrangia o período de 1984 a 1988 e as correlações encontradas foram muito próximas às do primeiro estudo (os valores não foram apresentados).

Em 1987, Irwin e Landa utilizaram retornos anuais no período de 1975 a 1985 para examinar o potencial de diversificação de carteiras compostas por ações e títulos (Chance, 1994). Os autores analisaram os efeitos da inclusão dos seguintes ativos nessas carteiras: cotas de fundos de commodities, contratos futuros e propriedades privadas (terrenos e imóveis). Os resultados das correlações entre esses ativos (Tabela 6) mostram resultados semelhantes aos de estudos anteriores, chegando-se à conclusão de que a inclusão de contratos futuros e propriedades privadas reduziam o risco da carteira em 50\% e aumentavam o retorno em $12 \%$.

Tabela 6. Correlações entre os retornos de ativos no período 1975-1985.

\begin{tabular}{lcc}
\hline & Contratos futuros & Fundo de commodities \\
\hline T-Bills & $-0,42$ & $-0,54$ \\
Títulos & $-0,33$ & $-0,47$ \\
Ações & $+0,22$ & $-0,56$ \\
Propriedades privadas & $+0,49$ & $+0,07$ \\
Fundo de commodities & $-0,03$ & $+1,00$ \\
\hline
\end{tabular}

Fonte: Irwin e Landa (Chance, 1994). Elaborada pelo autor.

Porém, no mesmo ano, Elton et al. publicaram um estudo importante a questionar a utilização de fundos de commodities (Chance, 1994). Foram comparados os retornos mensais sobre diversos ativos no período de junho de 1979 a junho de 1985. Os ativos considerados foram os fundos de commodities (cuja amostra variou de 12 a 85 fundos), ações representadas pelo índice S\&P500, ações de empresas de pequeno porte (equivalente a $20 \%$ das ações de menor capitalização da $\mathrm{NYSE}^{22}$ ), títulos privados de longo prazo (baseados no Shearson Lehman Bond Index), títulos públicos de longo prazo (também baseado no Shearson Lehman Bond Index) e T-Bills.

\footnotetext{
${ }^{22}$ Bolsa de Valores de Nova Iorque (New York Stock Exchange).
} 
Os fundos apresentaram correlação de $-0,121$ com o S\&P500, -0,003 com o Shearson Lehman Bond Index e +0,010 com os T-Bills (as demais correlações não foram apresentadas). Esses valores parecem compatíveis com a idéia de que a inclusão de commodities em carteiras compostas por ações e títulos é capaz de reduzir o risco das mesmas, visto que trabalhos anteriores chegaram a essa conclusão a partir de correlações de magnitudes semelhantes.

Porém, na montagem de carteiras combinando contratos futuros de commodities com ações e títulos, percebeu-se que o retorno médio destas carteiras apresentava redução mais que proporcional à redução do risco. Isso significa que a estratégia de diversificação reduzia tanto o risco como o retorno da carteira, sendo que a redução do seu retorno esperado anulava os efeitos benéficos de redução de risco.

Os mesmo autores voltaram ao ponto em outro artigo (Elton et al., 1990) no qual analisavam a atratividade de fundos de commodities. Foram analisados os desempenhos de mais de 130 fundos que negociavam contratos futuros entre 1980 e 1988 nos EUA e verificou-se que, neste período, eles apresentaram baixos retornos e elevado risco. Em seguida, tratou-se de analisar a possibilidade de incluir estes fundos em carteiras de ações e títulos.

Os autores então calcularam a correlação entre os retornos dos fundos e de ações e títulos no período analisado e concluíram que este coeficiente é positivo e muito próximo a zero $\left(0,08\right.$ com ações ${ }^{23}$ e 0,05 com títulos $\left.{ }^{24}\right)$. Dado este resultado, eles estabeleceram que somente se deveria considerar a inclusão dos fundos em carteiras de ações e títulos se oferecessem retornos superiores à taxa livre de risco (neste caso, títulos do Tesouro norteamericano). Como esta condição não foi verificada no período analisado, não foi possível encontrar evidências capazes de justificar esta estratégia de investimento.

\footnotetext{
${ }^{23}$ Índice Standard \& Poor's

${ }^{24}$ Shearson Lehman Corporate Government Bond Index
} 
A conclusão geral deste trabalho foi de que, dado o elevado nível de risco dos fundos de commodities entre 1980 e 1988, seus retornos não são suficientemente elevados para justificar uma estratégia de diversificação baseada na sua inclusão em carteiras de ações e títulos.

Conclusão semelhante foi encontrada na década seguinte por Irwin et al. (1993), que analisaram o desempenho de fundos de investimentos em commodities no período entre 1979 e 1990. Analisando o desempenho de todos os fundos de commodities negociados nos EUA entre janeiro de 1979 e dezembro de 1990, verificou-se que, em geral, esses fundos apresentaram retornos modestos. Tal constatação foi feita a partir da criação de uma carteira composta por todos esse fundos e da posterior comparação de seu retorno e desvio-padrão com outros tipos de investimentos (Tabela 7).

Tabela 7. Risco e retorno de diversos investimento nos EUA entre 1979 e 1990.

\begin{tabular}{lcc}
\hline \multicolumn{1}{c}{ Investimento } & $\begin{array}{c}\text { Retorno médio } \\
\text { mensal }\end{array}$ & $\begin{array}{c}\text { Desvio padrão do retorno } \\
\text { médio mensal (risco) }\end{array}$ \\
\hline $\begin{array}{l}\text { Carteira composta por todos os fundos } \\
\text { de commodities negociados }\end{array}$ & $0,968 \%$ & $6,414 \%$ \\
Ações & $1,225 \%$ & $4,711 \%$ \\
T-Bills & $0,715 \%$ & $0,222 \%$ \\
Títulos públicos de médio prazo & $0,877 \%$ & $2,181 \%$ \\
Títulos públicos de longo prazo & $0,861 \%$ & $3,924 \%$ \\
Títulos privados de longo prazo & $0,870 \%$ & $3,592 \%$ \\
\hline
\end{tabular}

Fonte: Irwin et al. (1993). Elaborada pelo autor.

A fraca performance dos fundos de investimento em commodities não implica necessariamente que eles devam ser ignorados pelos investidores. Supôs-se que esses fundos pudessem ser atrativamente incorporados a carteiras já existentes, lembrando do princípio da diversificação científica. No entanto, apesar de as correlações entre os retornos desses fundos e os retornos de ações e títulos variarem razoavelmente em cada ano do período analisado, verificou-se que existe uma tendência predominante de correlação 
próxima a zero (Tabela 8). Tal resultado sugere que os retornos dos fundos de commodities não são correlacionados aos retornos sobre ações ou títulos (Irwin et al., 1993).

Tabela 8. Correlação entre os retornos de fundos de commodities e de outros ativos no período 1979-1990.

\begin{tabular}{lc}
\hline \multicolumn{1}{c}{ Ativos } & Correlação \\
\hline Ações & 0,049 \\
T-Bills & 0,044 \\
Títulos públicos de médio prazo & 0,005 \\
Títulos públicos de longo prazo & 0,021 \\
Títulos privados de longo prazo & 0,048
\end{tabular}

Fonte: Irwin et al. (1993). Elaborada pelo autor.

Como o bom funcionamento do princípio da diversificação científica demanda correlações baixas entre os retornos dos ativos envolvidos, concluiu-se que a inclusão de fundos de commodities em carteiras de investimento com ações e títulos deveria ser considerada. Para testar esta hipótese, os autores utilizaram-se da mesma relação apresentada por Lintner (1997) sobre a razão de Sharpe.

Com base nos cálculos realizados, considerou-se razoável supor que a correlação entre os retornos dos fundos de commodities e das ações e títulos fosse igual a zero. Isso simplifica a relação a estabelece como condição para que fundos de commodities sejam incluídos em carteiras que a diferença entre o retorno esperado destes fundos e a taxa de juros livre de risco seja positiva. Ao testar estatisticamente esta regra, os autores concluíram que os valores obtidos não são significativamente diferentes de zero.

Desta forma, conclui-se que a inclusão de fundos de commodities em carteiras de ações e títulos não é capaz de melhorar seu desempenho. Por outro lado, considerou-se que esta estratégia também não é prejudicial à performance das carteiras. Portanto, os autores adotaram como conclusão mais adequada que a inclusão de fundos de commodities em carteiras de ações e títulos é neutra. 
Um estudo realizado por Ibbotson Associates (Chance, 1994) comparou o desempenho de cinco tipos de ativos no período entre janeiro de 1970 e abril de 1992: Goldman Sachs Commodity Index (GSCI) ${ }^{25}$, S\&P500, Morgan Stanley Europe, Asia and Far East (EAFE) Index ${ }^{26}, \mathrm{~T}$-Bonds (títulos do Tesouro norte-americano) e T-Bills.

As correlações entre os retornos destes ativos (Tabela 9) mostraram que o GSCI é negativamente correlacionado aos demais quatro ativos, ou seja, mostram que as commodities são negativamente correlacionadas a ações e títulos. A partir desta constatação e de cálculos posteriores (não apresentados no estudo) realizados pela Abbotson Associates, conclui-se que, dado um certo nível de retorno, a inclusão de commodities em uma carteira de ações e títulos pode reduzir o risco da mesma pela metade.

Tabela 9. Correlação entre os retornos de diversos ativos entre janeiro de 1970 e abril de 1992.

\begin{tabular}{lccccc}
\hline & GSCI & S\&P500 & EAFE Index & T-Bonds & T-Bills \\
\hline GSCI & $+1,00$ & $-0,42$ & $-0,27$ & $-0,32$ & $-0,20$ \\
S\&P500 & $-0,42$ & $+1,00$ & $+0,58$ & $+0,42$ & $-0,08$ \\
EAFE Index & $-0,27$ & $+0,58$ & $+1,00$ & $+0,20$ & $-0,31$ \\
T-Bonds & $-0,32$ & $+0,42$ & $+0,20$ & $+1,00$ & $-0,05$ \\
T-Bills & $-0,20$ & $-0,08$ & $-0,31$ & $-0,05$ & $+1,00$ \\
\hline
\end{tabular}

Fonte: Ibbotson Associates (Chance, 1994). Elaborada pelo autor.

Edwards e Park (1996) analisaram três tipos de investimentos em contratos futuros entre janeiro de 1983 e dezembro de 1992: fundos geridos por CTAs, fundos geridos por CPOs ${ }^{27}$ e fundos mútuos de commodities. Verificou-se que, em geral, os contratos futuros apresentavam retornos mais baixos e razões de Sharpe menores no período 1989-1992 do que no período 1983-1988.

Em seguida os autores tentaram verificar a viabilidade de incluir estes contratos em carteiras de ações e títulos, destacando como motivação principal desta estratégia a baixa correlação existente entre os retornos dos contratos futuros e a maioria dos demais ativos

\footnotetext{
${ }^{25}$ Índice elaborado pela corretora Goldman Sachs para medir o comportamento dos preços de uma cesta de commodities.

${ }^{26}$ Índice elaborado pela corretora Morgan Stanley para medir o comportamento de uma cesta de títulos de diversos países.

${ }^{27}$ Commodity Pool Operators (CPOs) são administradores de fundos de commodities.
} 
financeiros. Cálculos apresentados no trabalho mostravam que estes valores eram todos muito próximos a zero.

Os autores sugeriram como regra de decisão a mesma relação utilizada por Lintner (1997) e Irwin et al. (1993), que trata das razões de Sharpe dos contratos futuros e da carteira e também da correlação entre os retornos dos ativos envolvidos. A conclusão final foi de que a estratégia de incluir contratos futuros em carteiras de ações e títulos melhora o desempenho destas últimas em todos os casos estudados, embora a magnitude desse incremento varie de acordo com a situação analisada.

No Brasil encontrou-se poucos estudos sobre esse assunto. Um destes foi realizado por Silva (1998) e tratava da utilização de commodities em geral para reduzir o risco de carteiras indexadas passivamente ${ }^{28}$ nos EUA.

Nesse trabalho destacou-se que uma carteira de investimentos composta por commodities possui correlação positiva com a inflação e negativa com ações e ativos de renda fixa. Para provar tal afirmação, utilizou-se a matriz de correlações entre o DPCI ${ }^{29}$, S\&P500, ativos de renda fixa (não especificados no trabalho) e inflação para o período 1970-1993 (Tabela 10).

Tabela 10. Matriz de correlações para o período 1970-1993.

\begin{tabular}{lcccc}
\hline & DPCI & S\&P500 & Renda fixa & Inflação \\
\hline DPCI & $+1,00$ & $-0,13$ & $-0,33$ & $+0,23$ \\
S\&P500 & $-0,13$ & $+1,00$ & $+0,41$ & $-0,32$ \\
Renda fixa & $-0,33$ & $+0,41$ & $+1,00$ & $-0,61$ \\
Inflação & $+0,23$ & $-0,32$ & $-0,61$ & $+1,00$ \\
\hline
\end{tabular}

Fonte: Silva (1998). Elaborada pelo autor.

Lembrando os princípios da Teoria do Portfólio, o autor argumentou que a inclusão de commodities às carteiras de investimento "tem a propriedade, em princípio, de aumentar a

\footnotetext{
28 "Carteiras indexadas passivamente são carteiras de investimento que procuram acompanhar determinado índice - como Ibovespa, S\&P500 etc. -, simplesmente comprando uma carteira igual ao índice ou aplicando os recursos em renda fixa e comprando contratos futuros do respectivo índice" (Silva, 1998).

${ }^{29}$ O Daiwa Physical Commodity Index (DPCI) é um índice que mede o comportamento dos preços de uma cesta de commodities.
} 


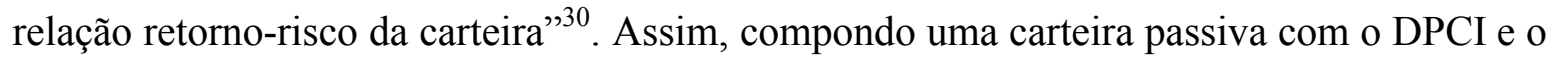
S\&P500 (em iguais proporções) no período entre 1970 e 1993, foi possível reduzir substancialmente o risco da mesma sem afetar de forma significativa seu retorno (Tabela $11)$.

Tabela 11. Risco e retorno do DPCI e S\&P500 individualmente e em uma carteira no período 19701993.

DPCI S\&P500 Carteira
(50\% DPCI e 50\% S\&P500)

\begin{tabular}{llll}
\hline Retorno anual médio & $12,64 \%$ & $12,58 \%$ & $12,61 \%$ \\
$\begin{array}{l}\text { Desvio padrão médio dos } \\
\text { retornos (risco) }\end{array}$ & $18,65 \%$ & $16,08 \%$ & $11,48 \%$ \\
\hline
\end{tabular}

Fonte: Daiwa Securities, Silva (1998). Elaborada pelo autor.

De acordo com Robert Greer, "historicamente, os benefícios em investir em commodities para uma carteira têm mostrado redução da volatilidade e, muitas vezes, aumento do retorno ao mesmo tempo" (Silva, 1998). Isso significa que, de acordo os dados analisados pelo autor, uma carteira composta pelo DPCI e pelo S\&P500 apresenta maior retorno e menor risco do que o S\&P500 tomado individualmente (Tabela 11).

Vale lembrar que os efeitos da diversificação de investimentos sobre o retorno e o risco de uma carteira são diferentes. O retorno da carteira será sempre uma média ponderada dos retornos dos ativos que a compõem, enquanto o risco não será simplesmente uma média ponderada dos riscos destes ativos. No exemplo apresentado por Silva (1988), uma carteira formada pelo DPCI e S\&P500 apresenta retorno esperado exatamente igual à média ponderada dos retornos dos dois índices, enquanto o risco desta carteira é inferior ao risco de ambos os índices (Tabela 11).

Silva (1998) destacou ainda que a vantagem da diversificação de investimentos por meio da utilização de commodities em carteiras de renda fixa não está apenas no desempenho destas propriamente dito, mas principalmente na constatação de que possuem correlação negativa

\footnotetext{
${ }^{30}$ Ao reduzir o risco de um carteira sem que seu retorno esperado seja reduzido mais que proporcionalmente, a relação retorno-risco é aumentada.
} 
com ativos de renda fixa (ou seja, com a taxa de juros). Segundo análise do JP Morgan ${ }^{31}$, "os maiores argumentos a favor da visão de que as commodities são uma classe de ativos de investimento não residem no ponto de vista do mercado e, sim, na teoria da diversificação de Markowitz” (Silva, 1998).

Por fim, ressaltou-se que ainda não existem dados históricos suficientes para análises semelhantes no Brasil. Mas é enfatizado que o crescimento dos negócios com contratos futuros de commodities na BM\&F já possibilita a composição de uma carteira com até sete commodities: milho, soja (complexo grãos), algodão, café, açúcar (complexo alimentos/fibras), boi gordo (complexo de alimentos vivos) e ouro (complexo metais). Em outras palavras, apesar de o mercado de commodities ser relativamente recente no Brasil, já existem instrumentos suficientes para compor carteiras indexadas a ativos financeiros e testar a redução da sua relação risco-retorno por meio da utilização de commodities.

Concluindo seu trabalho, Silva (1998) enfatizou que, segundo Robert Greer, "com toda a evidência apresentada nos últimos 16 anos, a questão não é mais se é prudente uma instituição estabelecer uma posição em commodities passivamente. A questão é se não alocar seria prudente".

Allen (1999) analisou a viabilidade de uma estratégia de inclusão de contratos futuros em carteiras de ações, títulos e taxas de juros em diversos países. O autor calculou os coeficientes de correlação entre os retornos de todos os ativos e então verificou o impacto da inclusão de contratos futuros em carteiras "típicas" de cada país (ou seja, os tipos de carteiras mais utilizados pelos administradores de recursos de cada país).

Os resultados obtidos mostraram que a correlação entre os retornos dos contratos futuros e dos demais ativos tende a ser muito próxima a zero (Tabela 12) e a inclusão destes contratos em carteiras é uma estratégia de investimentos recomendável. O autor encontrou

\footnotetext{
${ }^{31}$ Banco de investimentos norte-americano.
} 
também a proporção ótima de contratos futuros nas carteiras de investimento (de forma a maximizar sua eficiência ${ }^{32}$ ), que variava de $5 \%$ a $30 \%$ de acordo com o país.

Tabela 12. Coeficientes de correlação entre os retornos de contratos futuros e outros ativos em diversos países no período 1989-1998.

\begin{tabular}{lcccccc}
\hline & EUA & França & Alemanha & Japão & Suíça & Inglaterra \\
\hline $\begin{array}{l}\text { Ações no mercado } \\
\text { nacional }\end{array}$ & $+0,02$ & $+0,015$ & $-0,076$ & $-0,077$ & $-0,233$ & $-0,118$ \\
$\begin{array}{l}\text { Ações no mercado } \\
\text { internacional }\end{array}$ & $-0,06$ & $+0,052$ & $+0,055$ & $-0,081$ & $-0,001$ & $-0,076$ \\
$\begin{array}{l}\text { Títulos no mercado } \\
\text { nacional }\end{array}$ & $+0,08$ & $+0,170$ & $+0,165$ & $+0,105$ & $+0,029$ & $-0,015$ \\
$\begin{array}{l}\text { Títulos no mercado } \\
\text { internacional }\end{array}$ & - & $+0,089$ & $+0,178$ & - & $+0,026$ & $+0,052$ \\
$\begin{array}{l}\text { Taxas de juros no } \\
\text { mercado nacional }\end{array}$ & $+0,04$ & $+0,088$ & $+0,075$ & $+0,061$ & $+0,081$ & $+0,066$ \\
\hline
\end{tabular}

Fonte: Allen (1999). Elaborada pelo autor.

A conclusão de Allen (1999) foi de que a inclusão de contratos futuros em carteiras pode elevar seu retorno esperado e reduzir seu risco. No entanto, deve-se observar que, na maioria dos casos analisados, os retornos e os riscos dos contratos futuros são os mais elevados entre os ativos considerados. A correlação próxima a zero dos contratos com os demais ativos ajuda fazer com que o risco de uma carteira combinando todos eles seja menor. Por outro lado, o aumento do retorno esperado defendido pelo autor só é possível porque os retornos dos contratos futuros no período analisado foram suficientemente maiores que os retornos dos demais ativos para causar tal efeito.

\section{3 - Comentários finais}

Os estudos realizados sobre o tema desta dissertação parecem fortalecer a idéia de que commodities apresentam correlação baixa com ações e títulos. Assim, reforça-se também a idéia de que a inclusão de commodities em carteiras compostas por ações e títulos é capaz de levar à diversificação científica defendida por Markowitz (1952).

\footnotetext{
${ }^{32} \mathrm{O}$ autor mede a eficiência de um carteira por meio do quociente retorno / risco.
} 
No entanto, vale observar que nenhum destes estudos se preocupa em testar a hipótese de que os coeficientes de correlação entre os retornos de ações e contratos futuros e de títulos e contratos futuros sejam iguais a zero. Pelos resultados obtidos e pelos tamanhos das amostras utilizadas em algumas análises, pode-se supor que tal hipótese seria aceita caso fossem realizados testes estatísticos para tanto. Por outro lado, alguns autores [Bodie \& Rosansky (1984); Irwin \& Landa (Chance, 1994); Allen (1999)] basearam-se em séries relativamente pequenas, o que poderia distorcer o verdadeiro valor destes coeficientes (Hoel, 1971).

De qualquer forma, estes trabalhos parecem mais preocupados em analisar o comportamento dos ativos analisados em determinados períodos de tempo, sem maiores preocupações com a descoberta de regras gerais para formação de carteiras de investimento. Deve-se lembrar, inclusive, que as conclusões de todos os trabalhos discutidos são fortemente dependentes do período de tempo analisado em cada um deles.

Em geral, trabalhos que incluem dados da década de 70 [Lintner (1997), Irwin e Brorsen (Chance, 1994) e Lee et al. (1985), por exemplo] tendem a encontrar resultados mais favoráveis à inclusão de contratos futuros em carteiras de ações e títulos do que aqueles que se concentram em dados da década de 80 [Elton et al. (1990) e Irwin et al. (1993), por exemplo]. Isso ocorre porque os contratos futuros tenderam a apresentar elevados retornos no primeiro período, ao contrário do que se pôde verificar no segundo período.

Portanto, o período de tempo escolhido para as análises é fundamental porque reflete um determinado conjunto de eventos econômicos que pode influenciar (muitas vezes de forma decisiva) o desempenho dos ativos utilizados.

Além disso, o número de observações também deve ser tratado com bastante cuidado, pois amostras pequenas podem distorcer os resultados das análises de carteiras. Este problema foi observado por quase todos os trabalhos discutidos anteriormente. A maioria dos autores 
foi cuidadosa ao selecionar o tamanho de suas amostras e foram utilizadas séries de retornos contendo, no mínimo, 42 observações.

Em geral, o objetivo dos trabalhos era verificar a viabilidade de se incluir contratos futuros em carteiras de ações e/ou títulos como estratégia de redução de risco das mesmas. Portanto, pelos resultados apresentados, pode-se dizer que a utilização de commodities deve, pelo menos, ser considerada como uma estratégia de formação de carteiras de investimento. 


\section{5 - METODOLOGIA}

"We get too soon old and too late smart". Kirt C. Butler and Dale L. Domian

Uma vez apresentados diversos trabalhos analisando a combinação de ativos financeiros e contratos futuros em carteiras de investimento, foi possível perceber o potencial de redução de risco associado a esta estratégia. Agora parte-se para análise semelhante no mercado financeiro brasileiro.

Para tanto, serão analisados os desempenhos de uma carteira composta apenas por ações e de outras carteiras compostas por ações e contratos futuros agropecuários. Este processo será realizado em quatro etapas:

a) análise da relação retorno-risco de uma carteira de ações e de cada um dos contratos futuros agropecuários durante o período analisado;

b) verificação da correlação entre os retornos de ações e contratos futuros agropecuários, o que sinalizaria a possibilidade de redução de risco de uma carteira de ações por meio da inclusão de contratos futuros;

c) comparação dos desempenhos de uma carteira composta por ações e de outra composta por ações e um contrato futuro agropecuário; $\mathrm{e}$

d) verificação da viabilidade de se construir carteiras eficientes por meio da combinação de ações e contratos futuros agropecuários.

Antes de expor a metodologia que será utilizada em cada uma destas etapas, deve-se destacar quais ativos serão considerados neste trabalho e qual o período de tempo escolhido para a análise. 


\section{1 - Ativos considerados no trabalho}

O ativo considerado para representar a carteira de ações será o Ibovespa, que é o indicador utilizado para retratar o comportamento médio das ações mais negociadas na Bolsa de Valores de São Paulo (Bovespa). Embora sejam calculados outros índices de ações no mercado acionário brasileiro, o Ibovespa foi escolhido porque representa o desempenho médio da bolsa que responde por aproximadamente $85 \%$ do volume total transacionado em todas as bolsas de valores do Brasil. Além disso, é o indicador mais utilizado no mercado brasileiro para se avaliar fundos de investimento em ações e também serve de referência para muitas carteiras indexadas.

Embora o Ibovespa seja uma representação de uma carteira hipotética de ações, isso não compromete os resultados deste trabalho devido à sua representatividade. $\mathrm{O}$ uso deste índice poderia trazer problemas caso se desejasse alterar a formação da carteira de ações (por ser uma carteira preestabelecida, isso não seria possível neste trabalho). Porém, como o interesse deste estudo está na inclusão de contratos futuros agropecuários em uma carteira de ações, a maior preocupação é a representatividade desta carteira e não haverá a necessidade de alterar sua composição. Este tipo de análise é bastante comum na literatura, podendo-se encontrar exemplos semelhantes em Bodie \& Rosansky (1984), Elton et al. (1990), Chance (1994), Leite \& Sanvicente (1995), Lintner (1997), Silva (1998) e Allen (1999).

No caso dos contratos futuros agropecuários, serão utilizados os seis contratos negociados na Bolsa de Mercadorias e Futuros (BM\&F): café, algodão, milho, boi gordo, açúcar e soja. Embora sejam pouco representativos no mercado financeiro brasileiro (representam aproximadamente $1 \%$ do volume diário de negócios na BM\&F - Tabela 13), foram escolhidos por serem os únicos contratos futuros de produtos agropecuários existentes no Brasil.

Tabela 13. Participação dos principais ativos negociados na BM\&F no volume financeiro total da bolsa 


\begin{tabular}{lcccc}
\hline & 1996 & 1997 & 1998 & $1999^{(\mathrm{a})}$ \\
\hline Taxa de juros & $37,46 \%$ & $30,53 \%$ & $46,11 \%$ & $44,43 \%$ \\
Taxa de câmbio & $37,48 \%$ & $39,76 \%$ & $24,73 \%$ & $22,61 \%$ \\
Índice de ações & $11,40 \%$ & $12,53 \%$ & $11,09 \%$ & $9,93 \%$ \\
Agropecuários & $0,23 \%$ & $0,23 \%$ & $0,34 \%$ & $0,98 \%$ \\
\hline
\end{tabular}

Fonte: BM\&F

(a) até outubro

\section{2 - Período analisado}

Os dados utilizados neste trabalho serão relativos ao período de julho de 1994 a dezembro de 1998, ou seja, 54 meses. Essa escolha deve-se, basicamente, a dois motivos: a existência de poucos contratos futuros agropecuários sendo negociados continuamente antes desse período e a seqüência de programas de estabilização econômica entre meados das décadas de 80 e 90 .

Entre os seis contratos futuros existentes atualmente na BM\&F, apenas dois (boi gordo e café) já eram negociados continuamente antes de julho de 1994. Os demais contratos existentes hoje foram criados em setembro de 1995 (açúcar), outubro de 1995 (soja) e novembro de 1996 (milho e algodão). Estas diferentes datas de criação dos contratos futuros trouxeram conseqüências importantes para a realização deste trabalho. As 54 observações possíveis no período analisado (julho de 1994 a dezembro de 1998) somente foram verificadas para os contratos de boi gordo e café. No caso do açúcar e da soja foram utilizadas 38 observações (novembro de 1995 a dezembro de 1998), enquanto para o milho e o algodão foram consideradas 25 observações (dezembro de 1996 a dezembro de 1998).

A seqüência de programas de estabilização econômica a partir de meados da década de 80 também trouxe alguns problemas para as diversas séries de dados econômicos existentes no Brasil. Um dos principais foi a quebra de padrões de comportamento, o que afeta a análise histórica dessas séries. Na tentativa de solucionar tal inconveniente, decidiu-se analisar os dados referentes ao período posterior ao último destes programas, ou seja, o Plano Real. 


\section{3 - Fontes de dados}

Os dados necessários para este trabalho foram as cotações diárias do Ibovespa e de cada um dos seis contratos futuros agropecuários, a partir dos quais foi possível calcular todas as demais informações relevantes para a análise. Essas cotações foram obtidas na Associação Nacional de Instituições de Mercado Aberto (Andima) e na Bolsa de Mercadorias \& Futuros (BM\&F).

\section{4 - Cálculo das taxas de retorno de cada ativo e das carteiras}

Uma vez definidos o período de tempo e as fontes de dados, resta expor de que maneira foram cumpridas as quatro etapas citadas anteriormente. Primeiramente é necessário calcular as taxas de retorno do Ibovespa e dos contratos futuros agropecuários.

A taxa de retorno do Ibovespa é dada pela variação de seu valor durante determinado período de tempo. Como Bawa e Chakrin (1979) destacam que diversos autores já verificaram que os preços de ativos financeiros são bem aproximados pela distribuição lognormal, a taxa de retorno será expressa pelo logaritmo natural da variação do valor do ativo. Como este trabalho considera a periodicidade mensal, esta taxa é dada por:

$$
R_{t}^{I}=\ln \left(\frac{P_{t}^{I}}{P_{t-1}^{I}}\right)
$$

onde

$R_{t}^{I}=$ taxa de retorno do Ibovespa no mês t;

$P_{t}^{I}=$ cotação de fechamento do Ibovespa no último dia do mês t; e

$P_{t-1}^{I}=$ cotação de fechamento do Ibovespa no último dia do mês t-1.

No caso dos contratos futuros agropecuários, deve-se ter alguns cuidados no cálculo das taxas de retorno. Como um investidor pode assumir posições compradas (compra de 
contratos com a intenção de venda no futuro) ou vendidas (venda de contratos com a intenção de compra no futuro) neste mercado, deve-se calcular as taxas de retorno para ambas as posições. Bodie \& Rosansky (1984) consideraram o cálculo da taxa de retorno sobre contratos futuros apenas para posições compradas, ou seja:

$$
R C_{t}^{j}=\ln \left(\frac{P_{t}^{j}}{P_{t-1}^{j}}\right)
$$

onde

$R C_{t}^{j}=$ taxa de retorno de uma posição comprada no contrato futuro j no mês t;

$P_{t}^{j}=$ preço de ajuste do contrato futuro j no último dia do mês t; e

$P_{t-1}^{j}=$ preço de ajuste do contrato futuro j no último dia do mês t-1.

No caso de posições vendidas, pode-se seguir o mesmo princípio com uma adaptação:

$$
R_{V_{t}^{j}}^{j}=\ln \left(\frac{P_{t-1}^{j}}{P_{t}^{j}}\right)
$$

onde

$R_{V_{t}}^{j}=$ taxa de retorno de uma posição vendida no contrato futuro j no mês $\mathrm{t}$;

$P_{t}^{j}=$ preço de ajuste do contrato futuro j no último dia do mês t; e

$P_{t-1}^{j}=$ preço de ajuste do contrato futuro j no último dia do mês t-1.

Todos os preços de ajuste considerados são relativos ao primeiro vencimento do contrato futuro, pois é este que costuma concentrar os maiores volumes de negócios e de contratos em aberto $^{33}$.

Finalmente, a taxa de retorno da carteira combinando ações e contratos futuros é dada pela média ponderada dos retornos de cada um destes ativos: 


$$
R_{P}=w_{I} R_{t}^{I}+\sum_{j=1}^{n} w_{j} R_{t}^{j}
$$

onde

$R_{t}^{P}=$ retorno da carteira $\mathrm{P}$ no mês $\mathrm{t}$;

$w_{I}=$ participação do Ibovespa na carteira;

$R_{t}^{I}=$ retorno do Ibovespa no mês t;

$w_{i}=$ participação do contrato futuro $\mathrm{j}$ na carteira;

$R_{t}^{j}=$ retorno do contrato futuro j no mês t; e

$n=$ número de contratos futuros na carteira.

Assumindo que as taxas de retorno históricas do Ibovespa e dos contratos futuros sejam usadas como previsões para suas taxas futuras, pode-se calcular o retorno esperado de um portfólio combinando ações e contratos futuros por meio da equação:

$$
E\left(R^{P}\right)=w_{I} E\left(R^{I}\right)+\sum_{j=1}^{n} w_{j} E\left(R^{j}\right)
$$

onde

$R^{P}=$ retorno esperado da carteira $\mathrm{P}$;

$w_{I}=$ participação do Ibovespa na carteira;

$R^{I}=$ retorno esperado do Ibovespa;

$w_{i}=$ participação do contrato futuro $\mathrm{j}$ na carteira;

$R^{j}=$ retorno esperado do contrato futuro j;

$n=$ número de contratos futuros na carteira.

\footnotetext{
${ }^{33}$ Soma de todas as posições compradas (ou, de forma equivalente, vendidas) no mercado futuro.
} 
Neste caso, tem-se que os retornos esperados do Ibovespa e dos contratos futuros são dados pela média das observações de cada variável durante determinado período de tempo ${ }^{34}$. Isso ocorre porque se supõe que o desempenho médio dos ativos durante certo período seja uma aproximação de seu retorno esperado para o período seguinte. Portanto:

$$
E\left(R^{I}\right)=\frac{\sum_{t=1}^{n} R_{t}^{I}}{n}
$$

onde

$E\left(R^{I}\right)=$ retorno esperado do Ibovespa;

$R_{t}^{I}=$ retorno do Ibovespa no mês t;

$n$ = número de meses do período analisado; e

$$
E\left(R^{j}\right)=\frac{\sum_{t=1}^{n} R_{t}^{j}}{n}
$$

onde

$E\left(R^{j}\right)=$ retorno esperado do contrato futuro j;

$R_{t}^{j}=$ retorno do contrato futuro j no mês t; e

$n$ = número de meses do período analisado.

\section{5 - Cálculo do risco de cada ativo e das carteiras}

Conforme apresentado por Markowitz (1952), o risco de um ativo pode ser medido pela variância de seu retorno, ou seja, pelo segundo momento da sua distribuição de probabilidade. Portanto, o risco de cada ativo analisado neste trabalho foi dado pelo desvio do retorno em relação ao seu valor médio:

\footnotetext{
${ }^{34}$ Deve-se lembrar que o retorno esperado é um parâmetro associado a uma distribuição de probabilidade teórica, enquanto a média das observações de uma variável em dado período é o resultado de uma combinação de números de uma maneira particular. A igualdade de ambas ocorre apenas sob determinados pressupostos.
} 


$$
\operatorname{Var}\left(R^{j}\right)=\frac{\sum_{t=1}^{n}\left[R_{t}^{j}-E\left(R^{j}\right)\right]^{2}}{n}
$$

onde

$\operatorname{Var}\left(R^{j}\right)=$ variância do retorno do ativo j;

$E\left(R^{j}\right)=$ retorno esperado do ativo $\mathrm{j}$

$R_{t}^{j}=$ taxa de retorno do ativo j no mês t;

$n=$ número total de meses.

Para que não haja problemas de unidade de medida ao comparar-se risco e retorno, convém que ambos sejam medidos na mesma unidade. Portanto, como o cálculo da variância exige que os desvios das taxas de retorno sejam elevados ao quadrado, deve-se retornar à unidade original por meio da extração da raiz quadrada da variância. Assim, a medida de risco utilizada para comparar risco e retorno é o desvio-padrão do retorno:

$$
D P\left(R^{j}\right)=\sqrt{\operatorname{Var}\left(R^{j}\right)}
$$

onde

$D P\left(R^{j}\right)=$ desvio-padrão do retorno do ativo $\mathrm{j}$; e

$\operatorname{Var}\left(R^{j}\right)=$ variância do retorno do ativo $\mathrm{j}$.

No caso de uma carteira, o cálculo do risco segue a mesma lógica, ou seja, o risco de uma carteira foi dado pela variância de seu retorno. Porém, como foi apresentado na equação (34), o retorno de uma carteira é uma média ponderada dos retornos dos ativos que a compõem.

Mais especificamente, os retornos das carteiras consideradas neste trabalho são dados pelas médias ponderadas dos retornos do Ibovespa e dos contratos futuros agropecuários que as compõem. Assim, a variância das carteiras deste trabalho é equivalente a: 


$$
\operatorname{Var}\left(R_{P}\right)=\operatorname{Var}\left(w_{I} R_{t}^{I}+\sum_{j=1}^{n} w_{j} R_{t}^{j}\right)
$$

Para facilidade de demonstração e sem perda de generalidade, pode-se considerar uma carteira composta apenas pelo Ibovespa e por um contrato futuro j:

$$
\begin{gathered}
\operatorname{Var}\left(R_{P}\right)=\operatorname{Var}\left(w_{I} R_{t}^{I}+w_{j} R_{t}^{j}\right) \\
\operatorname{Var}\left(R_{P}\right)=\frac{\sum_{t=1}^{n}\left[\left(w_{I} R_{t}^{I}+w_{j} R_{t}^{j}\right)-E\left(w_{I} R_{t}^{I}+w_{j} R_{t}^{j}\right)\right]^{2}}{n} \\
\operatorname{Var}\left(R_{P}\right)=\frac{\sum_{t=1}^{n}\left\{\left[w_{I} R_{t}^{I}-E\left(w_{I} R_{t}^{I}\right)\right]+\left[w_{j} R_{t}^{j}-E\left(w_{j} R_{t}^{j}\right)\right]\right\}^{2}}{n} \\
\sum_{t=1}^{n}\left\{\left[w_{I} R_{t}^{I}-E\left(w_{I} R_{t}^{I}\right)\right]^{2}+2\left[w_{I} R_{t}^{I}-E\left(w_{I} R_{t}^{I}\right)\right]\left[w_{j} R_{t}^{j}-E\left(w_{j} R_{t}^{j}\right)\right]+\left[w_{j} R_{t}^{j}-E\left(w_{j} R_{t}^{j}\right)\right]^{2}\right\} \\
\operatorname{Var}\left(R_{P}\right)=\operatorname{Var}\left(w_{I} R_{t}^{I}\right)+2 \operatorname{Cov}\left(w_{I} R_{t}^{I}, w_{j} R_{t}^{j}\right)+\operatorname{Var}\left(w_{j} R_{t}^{j}\right)
\end{gathered}
$$

Como os valores de w são constantes:

$$
\operatorname{Var}\left(R_{P}\right)=w_{I}^{2} \operatorname{Var}\left(R^{I}\right)+2 w_{I} w_{j} \operatorname{Cov}\left(R^{I}, R^{j}\right)+w_{j}^{2} \operatorname{Var}\left(R^{j}\right)
$$

Generalizando o resultado da equação (41) para uma carteira composta pelo Ibovespa e por mais de um contrato futuro agropecuário, tem-se que sua variância foi dada por:

$$
\operatorname{Var}\left(R_{P}\right)=\sum_{i=1}^{n} w_{i}^{2} \operatorname{Var}\left(R^{i}\right)+\sum_{i=1}^{n} \sum_{\substack{k=1 \\ k \neq i}}^{n} w_{i} w_{k} \operatorname{Cov}\left(R^{i}, R^{k}\right)
$$


onde

$\operatorname{Var}\left(R_{P}\right)=$ variância do retorno da carteira;

$\operatorname{Var}\left(R^{i}\right)=$ variância do retorno do ativo i que compõem esta carteira;

$w_{i}=$ participação do ativo i na carteira;

$\operatorname{Cov}\left(R^{i}, R^{k}\right)=$ covariância entre os retornos dos ativos que compõem a carteira; e $n=$ número de ativos da carteira.

Portanto, o risco de uma carteira depende não apenas das variâncias dos retornos dos ativos que a compõe, mas também das covariâncias entre os retornos destes ativos.

\section{6 - Análise do coeficiente de correlação entre os retornos de ações e contratos futuros agropecuários}

O coeficiente de correlação exerce papel importante na Teoria do Portfólio, pois, como destaca Markowitz (1959), uma estratégia de diversificação científica de investimentos somente é viável se forem combinados ativos cujos retornos apresentem correlação inferior $\mathrm{a}+1$.

Como este trabalho dispõe apenas de uma amostra dos retornos do Ibovespa e dos contratos futuros agropecuários, o coeficiente de correlação entre os retornos do Ibovespa e de cada um dos contratos futuros pode ser estimado por (Hoel, 1971):

$\rho_{I, j}=\frac{\sum_{t=1}^{N}\left[R_{t}^{I}-E\left(R^{I}\right)\right]\left[R_{t}^{j}-E\left(R^{j}\right)\right]}{\sqrt{\sum_{t=1}^{N}\left[R_{t}^{I}-E\left(R^{I}\right)\right]^{2} \sum_{t=1}^{N}\left[R_{t}^{j}-E\left(R^{j}\right)\right]^{2}}}$

onde

$\rho_{i, j}=$ coeficiente de correlação entre os retornos do Ibovespa e do contrato futuro j;

$R_{t}^{k}=$ retorno do ativo k no mês t; 
$E\left(R^{k}\right)=$ retorno esperado do ativo $\mathrm{k} ; \mathrm{e}$

$N=$ número de observações da amostra.

Lembrando que o coeficiente de correlação e a covariância são medidas relacionadas, temse que (Hoel, 1971):

$$
\rho_{i, j}=\frac{\operatorname{Cov}\left(R^{i}, R^{j}\right)}{\sigma_{i} \sigma_{j}}
$$

onde

$\rho_{i, j}=$ coeficiente de correlação entre os retornos dos ativos i e j;

$\operatorname{Cov}\left(R^{i}, R^{j}\right)=$ covariância entre os retornos dos ativos i e j; e

$\sigma_{k}=$ desvio-padrão do retorno do ativo k.

Portanto, o risco de uma carteira também pode ser expresso em função do coeficiente de correlação entre os retornos dos ativos que a compõem. Substituindo (44) na equação (42), tem-se:

$$
\operatorname{Var}\left(R_{P}\right)=\sum_{i=1}^{n} w_{i}^{2} \operatorname{Var}\left(R^{i}\right)+\sum_{i=1}^{n} \sum_{\substack{k=1 \\ k \neq i}}^{n} w_{i} w_{k} \sigma_{i} \sigma_{k} \rho_{i, k}
$$

onde

$\operatorname{Var}\left(R_{P}\right)=$ variância do retorno da carteira;

$\operatorname{Var}\left(R^{i}\right)=$ variância do retorno do ativo i que compõe esta carteira;

$w_{i}=$ participação do ativo i na carteira;

$\rho_{i, k}=$ coeficiente de correlação entre os retornos dos ativos i e k;

$\sigma_{q}=$ desvio-padrão do retorno do ativo q; e

$n=$ número de ativos da carteira. 
Como foi ressaltado anteriormente, este trabalho dispõe apenas de uma amostra dos retornos do Ibovespa e dos contratos futuros agropecuários. Ao considerar-se apenas uma amostra da população de retornos destes ativos, pode-se obter estimativas bastante distorcidas do verdadeiro valor da correlação (Hoel, 1971). Na tentativa de evitar este problema, pode-se recorrer a um teste estatístico para verificar o resultado amostral do coeficiente de correlação. Como se supõe que a correlação entre os retornos de ações e futuros agropecuários seja próxima de zero ${ }^{35}$, é possível utilizar um teste estatístico para verificar se esta correlação pode realmente ser nula. Para tanto, estabelece-se a hipótese de que os retornos de ações e futuros agropecuários não são correlacionados e realiza-se um teste t (Hoel, 1971):

$$
\begin{aligned}
& H_{0}: \rho=0 \quad H_{A}: \rho \neq 0 \\
& t=\frac{r \sqrt{n-2}}{\sqrt{1-r^{2}}}
\end{aligned}
$$

onde

$\mathrm{t}=$ estatística $\mathrm{t}$ utilizada no teste;

$\mathrm{r}=$ coeficiente de correlação da amostra; e

$\mathrm{n}=$ número de observações da amostra.

Dado um determinado nível de significância, a hipótese de correlação nula não pode ser rejeitada se o valor calculado de $\mathrm{t}$ for menor que o valor crítico (tabelado) de $\mathrm{t}$. Caso contrário, não será possível aceitar a hipótese de correlação nula.

Portanto, este teste foi utilizado para verificar se seria possível afirmar que a correlação entre os retornos do Ibovespa e dos contratos futuros é igual a zero. Se isso fosse verdadeiro, poder-se-ia confirmar os coeficientes amostrais e ratificar que existe a possibilidade de utilização conjunta destes ativos em uma estratégia de diversificação

\footnotetext{
${ }^{35}$ Cálculos realizados e não publicados pelo autor.
} 
científica de investimentos (vale notar que tal estratégia seria viável para qualquer outro valor diferente de 1).

\section{7 - Carteiras combinando ações e contratos futuros agropecuários}

Uma vez analisados o retorno e o risco dos ativos considerados neste trabalho e também a correlação entre os retornos destes ativos, partiu-se para a análise do desempenho de carteiras combinando ações e contratos futuros agropecuários. Esta tarefa foi realizada em duas etapas. Primeiramente, comparou-se os desempenhos de uma carteira composta apenas por ações com outras compostas por ações e um contrato futuro agropecuário.

Esta comparação foi feita da seguinte maneira: partindo-se de uma carteira composta apenas por ações (representada aqui pelo Ibovespa), passou-se a incluir paulatinamente um contrato futuro e permitiu-se que a participação deste contrato crescesse progressivamente em detrimento da participação do Ibovespa.

Por exemplo, partiu-se de uma carteira representada pela Ibovespa (ou seja, 100\% de ações) e incluiu-se o contrato futuro de café de forma que este representasse $1 \%$ da carteira, deixando o Ibovespa representar então 99\% da carteira. Em seguida passou-se a aumentar a participação do contrato futuro e reduzir a participação do Ibovespa ( $2 \%$ de contrato futuro e $98 \%$ de Ibovespa, 3\% de contrato futuro e 97\% de Ibovespa e assim sucessivamente) até o momento em que não houvesse mais ações na carteira (ou seja, 100\% de contrato futuro).

Este processo gerou um conjunto de pontos representando carteiras com diversas combinações de ações e contratos futuros, a partir do qual foi possível calcular o retorno e o risco da mesma. Estes cálculos foram realizados de acordo com as equações (33) e (41), utilizando os dados históricos para calcular os retornos, as variâncias dos retornos e os coeficientes de correlação entre os retornos de cada ativo. 
Este conjunto de pontos representa diversas combinações de retorno e risco para carteiras de investimento, que, em geral, deveriam atender ao princípio que estabelece que maiores patamares de retorno tendem a ser acompanhados por maiores níveis de risco e vice-versa. Portanto, é conveniente que se utilize uma medida de desempenho para avaliar adequadamente as combinações entre retorno e risco das carteiras formadas.

Baseando-se nos trabalhos de Irwin et. al (1993), Edwards \& Park (1996) e Lintner (1997), a medida escolhida foi o Índice de Sharpe, que mede o retorno obtido acima da taxa livre de risco por unidade de risco assumida pelo investidor (Sharpe, 1966; Tobin, 1958):

$$
I S=\frac{E\left(R_{i}\right)-R_{F}}{\sigma_{i}}
$$

onde

$E\left(R_{i}\right)$ é o retorno esperado da carteira $i$;

$\mathrm{R}_{\mathrm{F}}$ é a taxa livre de risco; e

$\sigma_{i}$ é o desvio-padrão do retorno da carteira i.

O retorno esperado da carteira i e seu desvio-padrão foram calculados com base em dados históricos, conforme explicado anteriormente. A taxa livre de risco para um dado período foi considerada como a média aritmética simples de seus valores durante o período analisado.

A taxa livre de risco utilizada para estes cálculos foi a Selic, que representa a remuneração dos títulos públicos brasileiros. Segundo Securato (1999), esses títulos são de grande liquidez e de mínimo risco, visto que são emitidos pelo governo e aceitos pelo mercado como se fossem dinheiro. Desta forma, as taxas desses títulos são os grandes balizadores do mercado em termos de formação de taxas de juros. Portanto, "ela [Selic] representa o que se chama na literatura de taxa livre de risco, em termos de Brasil”' (Securato, 1999, p.124). 
Um Índice de Sharpe positivo significa que determinado ativo ofereceu um prêmio positivo pelo risco assumido, enquanto um índice negativo mostra que dado ativo ofereceu prêmio negativo pelo risco assumido. Se o índice for maior que 1, têm-se que o prêmio oferecido foi proporcionalmente maior que o risco assumido. Para valores entre 0 e 1, o índice mostra que o prêmio oferecido foi proporcionalmente menor que o risco assumido.

Dessa forma, ativos com valores mais elevados para o Índice de Sharpe são preferíveis àqueles com valores menores, pois os primeiros estariam oferecendo maior retorno por unidade de risco assumida. Portanto, as diversas combinações de retorno e risco das carteiras formadas serão ordenadas de acordo com os valores de seus Índices de Sharpe.

Esta tarefa será realizada seis vezes, ou seja, para cada um dos seis contratos futuros agropecuários que forem combinados com o Ibovespa em uma carteira hipotética. Uma vez encerrada esta etapa, será possível verificar até que ponto a inclusão de contratos futuros em carteiras de ações consegue incrementar a relação retorno-risco das mesmas.

A segunda etapa da análise do desempenho de carteiras combinando ações e contratos futuros agropecuários é a verificação da viabilidade de se construir carteiras eficientes com estes ativos. A intenção aqui é verificar a possibilidade de se construir carteiras com ações e contratos futuros que apresentem o menor nível de risco possível para um dado patamar de retorno ou ainda o maior patamar de retorno possível para um determinado nível de risco.

Para tanto tomou-se o Ibovespa e os seis contratos futuros agropecuários e tentou-se construir carteiras eficientes por meio do algoritmo desenvolvido por Markowitz (1959). Este expressa um problema de minimização do risco, ou seja, um investidor buscaria minimizar o risco de seu investimento sujeito a um determinado nível de retorno esperado. Analogamente, pode-se considerar um problema de maximização do retorno esperado dado um certo nível de risco. Assim, para o caso de $\mathrm{N}$ ativos, tem-se: 
$\operatorname{minimizar} \quad \operatorname{Var}\left(R_{p}\right)=\sum_{j=1}^{N} w_{j}^{2} \operatorname{Var}\left(X_{j}\right)+\sum_{j=1}^{N} \sum_{\substack{k=1 \\ k \neq j}}^{N} w_{j} w_{k} \operatorname{Cov}\left(X_{j}, X_{k}\right)$

sujeito a $\quad E\left(R_{p}\right)=w_{1} R_{1}+w_{2} R_{2}+\ldots+w_{N} R_{N}=\sum_{i=1}^{N} w_{i} R_{i}=\overline{R_{p}}$

$$
\begin{aligned}
& \sum_{i=1}^{N} w_{i}=1 \\
& w_{i} \geq 0, \mathrm{i}=1, \ldots, \mathrm{N} .
\end{aligned}
$$

ou então

$$
\begin{array}{ll}
\text { maximizar } & E\left(R_{p}\right)=w_{1} R_{1}+w_{2} R_{2}+\ldots+w_{N} R_{N}=\sum_{i=1}^{N} w_{i} R_{i} \\
\text { sujeito a } & \operatorname{Var}\left(R_{p}\right)=\sum_{j=1}^{N} w_{j}^{2} \operatorname{Var}\left(X_{j}\right)+\sum_{\substack { j=1 \\
\begin{subarray}{c}{k \neq 1 \\
k \neq j{ j = 1 \\
\begin{subarray} { c } { k \neq 1 \\
k \neq j } }\end{subarray}}^{N} w_{j} w_{k} \operatorname{Cov}\left(X_{j}, X_{k}\right)=\overline{\operatorname{Var}\left(R_{p}\right)} \\
& \sum_{i=1}^{N} w_{i}=1 \\
& w_{i} \geq 0, \mathrm{i}=1, \ldots, \mathrm{N} .
\end{array}
$$

Terminada esta etapa, será possível verificar se é possível gerar fronteiras eficientes de investimentos por meio da combinação de ações e contratos futuros agropecuários em carteiras. É possível também verificar se esta combinação seria capaz de gerar carteiras mais eficientes que o Ibovespa.

Porém, neste ponto cabe lembrar que não se deve assumir que o Ibovespa é uma carteira eficiente. Nakamura (1998) avaliou o desempenho da carteira teórica do Ibovespa entre maio de 1988 e abril de 1997, ou seja, durante 27 quadrimestres (a composição desta carteira é reavaliada a cada quatro meses). Tomando individualmente as ações componentes do Ibovespa em cada quadrimestre, Nakamura (1998) determinou dois conjuntos de carteiras de mínima variância: um considerando a mínima variância global e outro considerando a mínima variância, dado o mesmo retorno médio do Ibovespa. Para tanto, utilizou-se do algoritmo proposto por Markowitz (1959): 
$\operatorname{minimizar} \quad \operatorname{Var}\left(R_{p}\right)=\sum_{j=1}^{N} w_{j}^{2} \operatorname{Var}\left(X_{j}\right)+\sum_{j=1}^{N} \sum_{\substack{k=1 \\ k \neq j}}^{N} w_{j} w_{k} \operatorname{Cov}\left(X_{j}, X_{k}\right)$

sujeito a $\quad \sum_{i=1}^{N} w_{i}=1$

$w_{i} \geq 0, \mathrm{i}=1, \ldots, \mathrm{N}$.

e

$$
\begin{array}{ll}
\operatorname{minimizar} & \operatorname{Var}\left(R_{p}\right)=\sum_{j=1}^{N} w_{j}^{2} \operatorname{Var}\left(X_{j}\right)+\sum_{j=1}^{N} \sum_{\substack{k=1 \\
k \neq j}}^{N} w_{j} w_{k} \operatorname{Cov}\left(X_{j}, X_{k}\right) \\
\text { sujeito a } & E\left(R_{p}\right)=w_{1} R_{1}+w_{2} R_{2}+\ldots+w_{N} R_{N}=\sum_{i=1}^{N} w_{i} R_{i}=\overline{R_{p}} \\
& \sum_{i=1}^{N} w_{i}=1 \\
& w_{i} \geq 0, \mathrm{i}=1, \ldots, \mathrm{N} .
\end{array}
$$

As carteiras obtidas por meio dos algoritmos representados em (51) e (52) "não guardam nenhuma relação com as carteiras teóricas do índice Bovespa em cada quadrimestre. É interessante observar que é necessário um número significativamente menor de títulos para compor as carteiras eficientes do ponto de vista do modelo de Markowitz" (Nakamura, 1998, p.89). As carteiras de mínima variância obtidas por Nakamura (1998) eram constituídas, em média, de $28 \%$ do total de ações que formavam o Ibovespa em cada período. Calculando o Índice de Sharpe para as carteiras analisadas, Nakamura (1998) verificou que existia uma melhor relação entre risco e retorno naquelas de mínima variância do que no Ibovespa.

Entre as carteiras obtidas por meio do algoritmo representado por (51) e (52), Nakamura (1998) estudou ainda quais eram, em cada período analisado, as carteiras com maior índice de Sharpe. Com isso, foi possível constatar que todas estas carteiras (a) apresentavam índices de Sharpe superiores ao do Ibovespa e (b) eram formadas por um menor número de ações do que o Ibovespa. 
Desta forma, "os resultados acima apresentados e discutidos comprovam a idéia de que o índice Bovespa, pela sua metodologia de construção, não é uma carteira localizada sobre a fronteira eficiente de Markowitz. Efetivamente, existem carteiras eficientes com desempenho superior ao do índice Bovespa, mesmo considerando uma amostra constituída apenas das ações que formaram o índice, ou seja, aquelas que foram no passado as mais negociadas “ (Nakamura, 1998, p.91).

Feitas as análises empíricas, Nakamura (1998) utilizou o teste de Gibbons, Ross e Shanken para testar estatisticamente a eficiência da carteira teórica do Ibovespa. Neste contexto, o teste de eficiência de uma carteira equivale a testar se o seu índice de Sharpe é o maior dentre os índices de todas as carteiras possíveis. O teste utilizado se aproxima de uma estatística F com N e T-N-1 graus de liberdade, sendo $\mathrm{N}$ a quantidade de ativos em uma carteira e $\mathrm{T}$ o número de observações. Ao contrário do que as evidências empíricas mostravam, Nakamura (1998) constatou que não era possível rejeitar a hipótese de eficiência da carteira. No entanto, o mesmo autor lembra que o resultado deste teste deve ser discutido levando em conta as condições estabelecidas em seu trabalho, ou seja, este resultado pode ser alterado caso sejam impostas condições menos restritivas na construção das carteiras de variância mínima (Nakamura, 1998).

Portanto, pode-se considerar que o Ibovespa não deve ser considerado uma carteira eficiente. Isso significa que a verificação de que existem carteiras compostas por ações e contratos futuros mais eficientes que o Ibovespa não implica que estas sejam as únicas combinações de ativos mais eficientes que o Ibovespa no mercado brasileiro. 


\section{6 - RESULTADOS}

"It's all chance but we can't stop now". John Galsworthy

A seguir serão apresentados e discutidos os resultados encontrados nas quatro etapas propostas anteriormente.

\section{1 - Análise da relação retorno-risco de uma carteira de ações e de cada um dos contratos futuros agropecuários durante o período analisado}

Analisando as diversas taxas de retorno verificadas no período de julho de 1994 a dezembro de 1998 para o Ibovespa e os contratos futuros agropecuários (posições compradas e vendidas), percebe-se que os retornos do Ibovespa tendem a superar os dos demais ativos em questão (Tabela 14). As melhores oportunidades de ganho com os contratos futuros surgiram nas posições vendidas durante o período analisado, como nos casos do boi gordo e do café em 1995 e do açúcar e do café em 1998 (Tabela 14). Essas datas revelam ainda outro ponto: as melhores oportunidades de ganhos com os contratos futuros agropecuários foram verificadas em subperíodos específicos, ou seja, não houve uma tendência consistente de retornos elevados para estes ativos entre julho de 1994 e dezembro de 1998. 


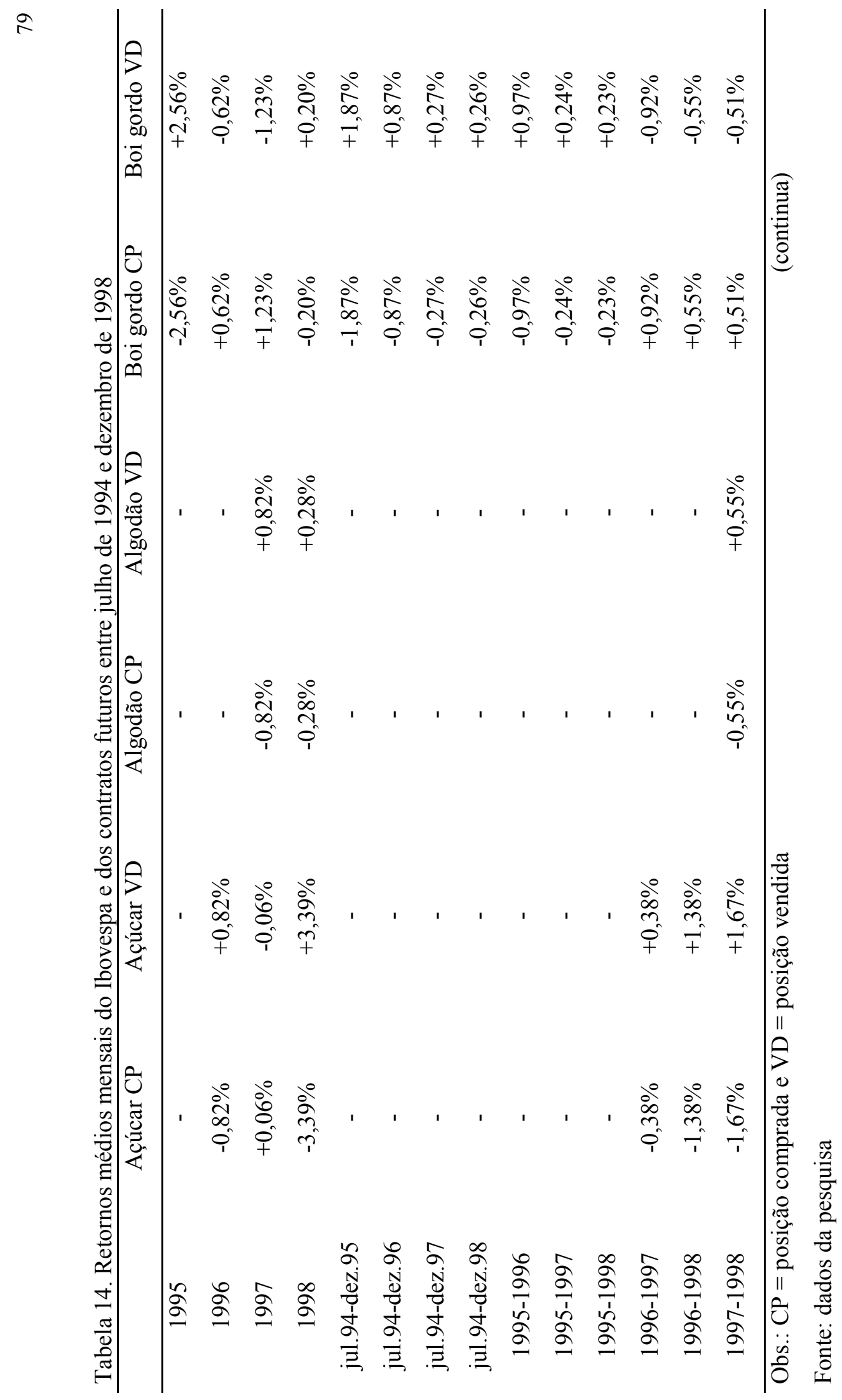




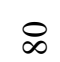

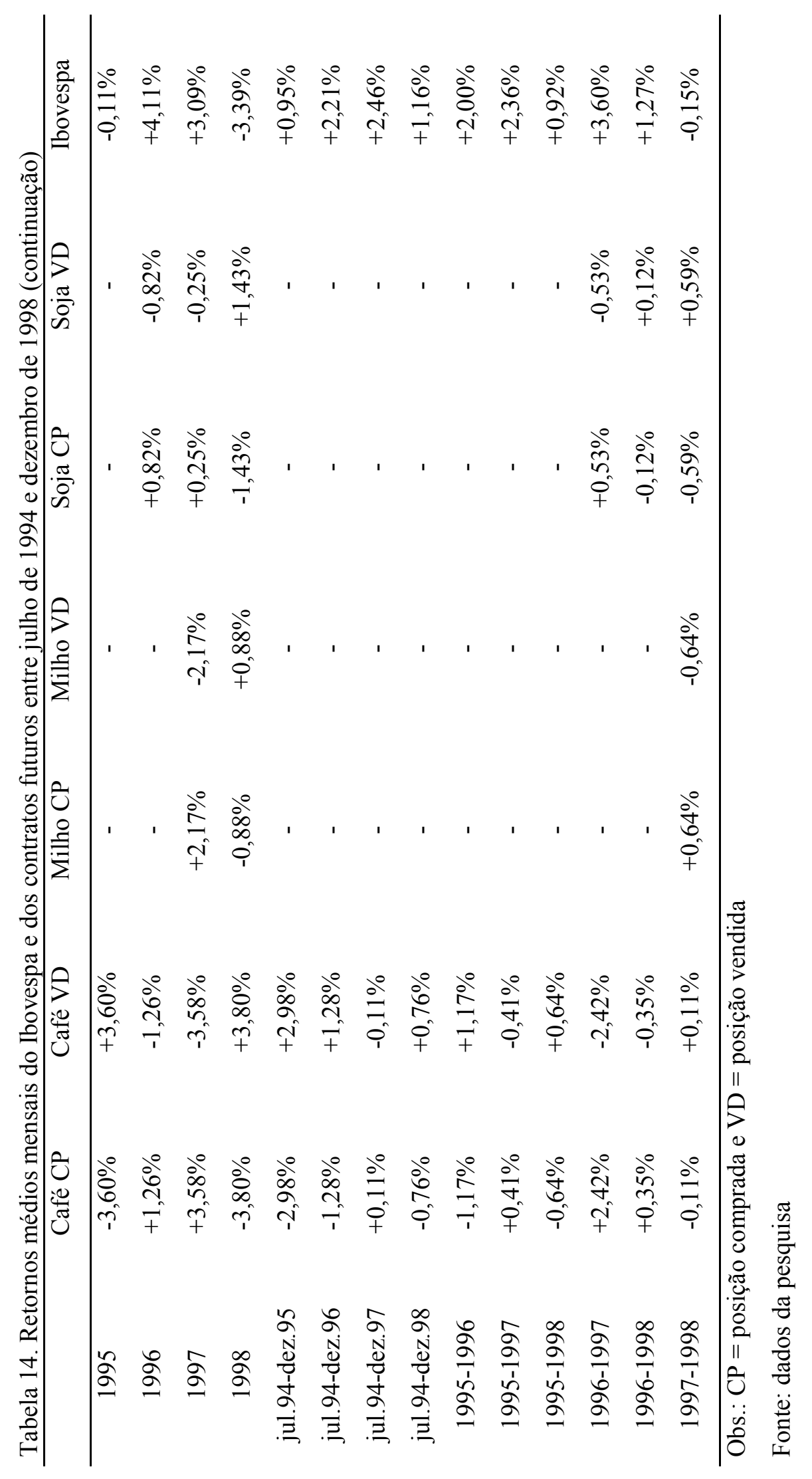


Portanto, um investidor não se sentiria motivado a buscar contratos futuros agropecuários se tivesse por objetivo maiores retornos para sua carteira. Lembrando que o retorno de uma carteira é uma média ponderada dos retornos dos ativos que a compõem, a inclusão de contratos futuros em uma carteira de ações durante o período estudado reduziria o retorno do investidor na maioria dos casos.

Com relação ao risco de cada ativo, verificou-se que os contratos futuros mostraram-se mais arriscados do que o Ibovespa na maior parte dos subperíodos analisados (Tabela 15). O destaque ficou por conta dos contratos de café, que apresentaram valores consistentemente elevados para o desvio-padrão dos seus retornos e constituíram-se nos ativos mais arriscados do período.

O Ibovespa, por sua vez, apresentou desvios-padrões dos seus retornos muitas vezes próximos aos dos contratos futuros (mas apenas em poucos períodos superiores a eles). De qualquer forma, todos os ativos considerados apresentaram risco relativamente alto, sugerindo que deveria ser tentada uma estratégia de diversificação de investimentos como forma de reduzir o risco total assumido pelo investidor. 


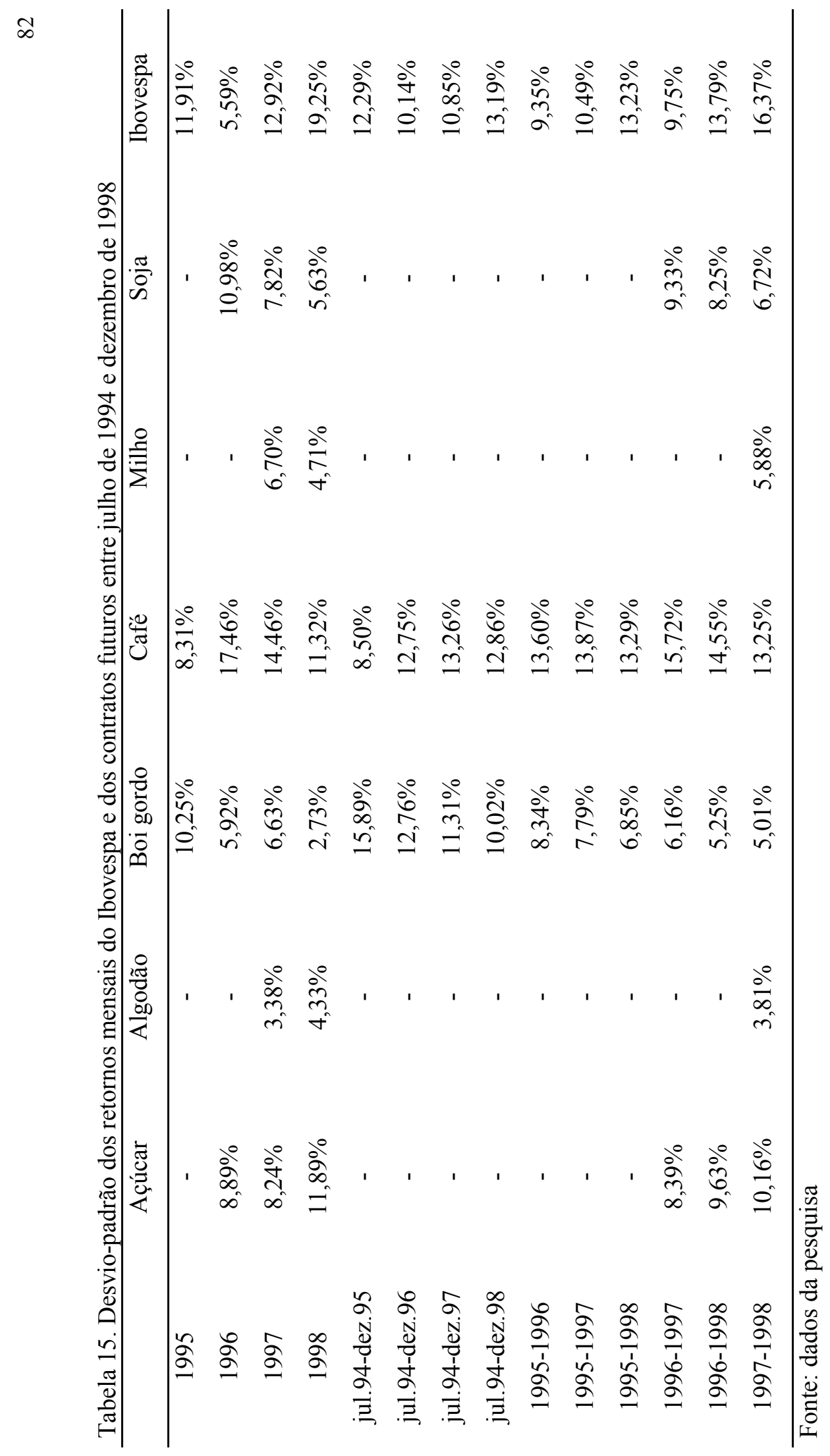


Por fim, os riscos relativamente elevados dos ativos analisados tendem a reduzir os valores de seus respectivos Índices de Sharpe. Isso ainda é agravado pelos baixos retornos apresentados pelos contratos futuros, o que acaba tornando os índices negativos na maioria dos subperíodos analisados (Tabela 16).

O Ibovespa destaca-se dos contratos futuros agropecuários por apresentar Índices de Sharpe superiores na grande maioria dos casos considerados. Afinal de contas, além de apresentarem retornos baixos, os contratos futuros mostram também risco elevado ${ }^{36}$. Assim, como já foi sugerido na análise dos retornos, o Índice de Sharpe também mostrou que os contratos futuros apresentaram-se pouco atrativos se tomados individualmente.

\footnotetext{
${ }^{36}$ Retornos baixos tendem a reduzir o valor do numerador do Índice de Sharpe, enquanto risco elevado tende a aumentar o valor do denominador. Juntando ambos os efeitos, surge uma clara tendência de redução do índice.
} 


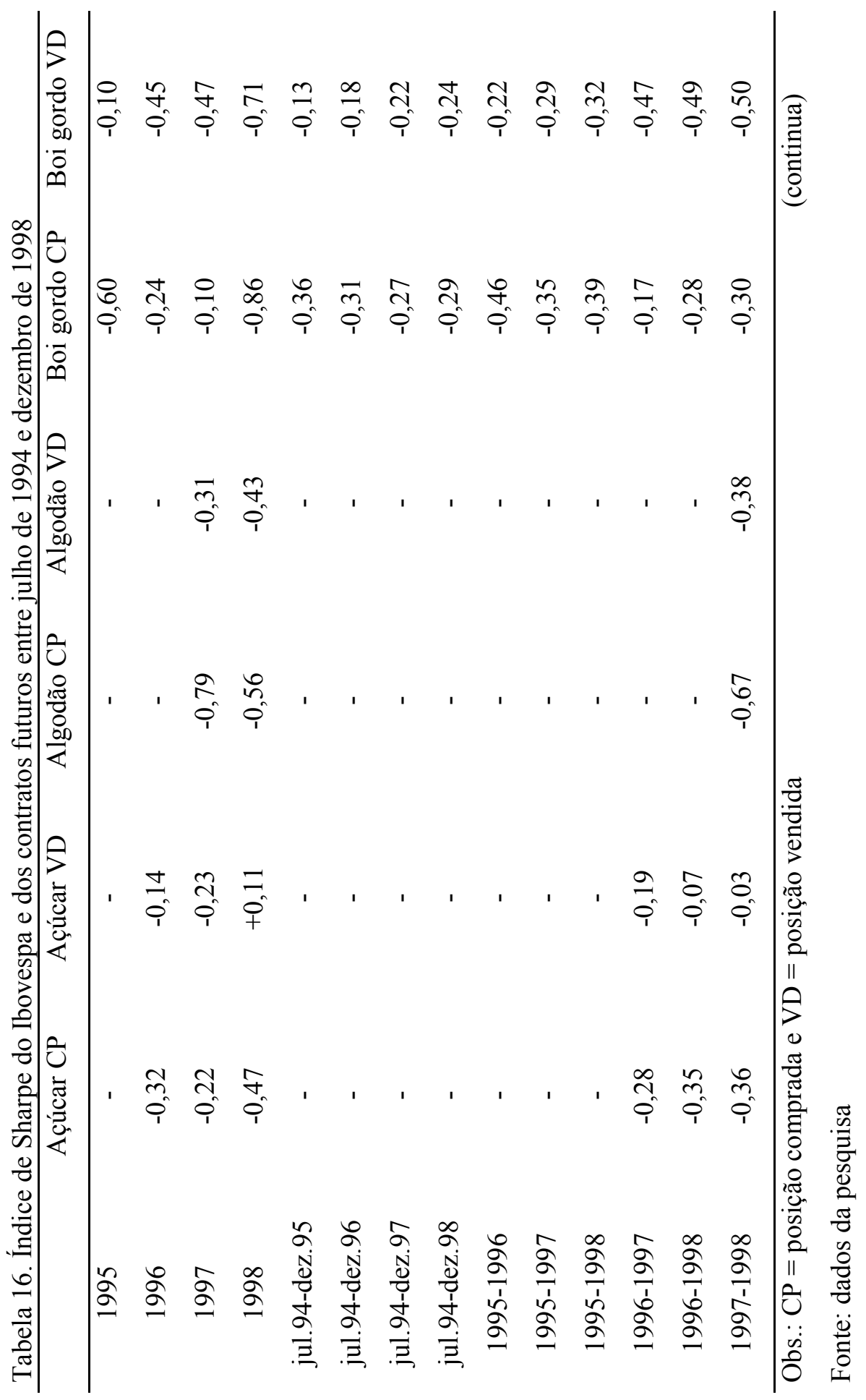




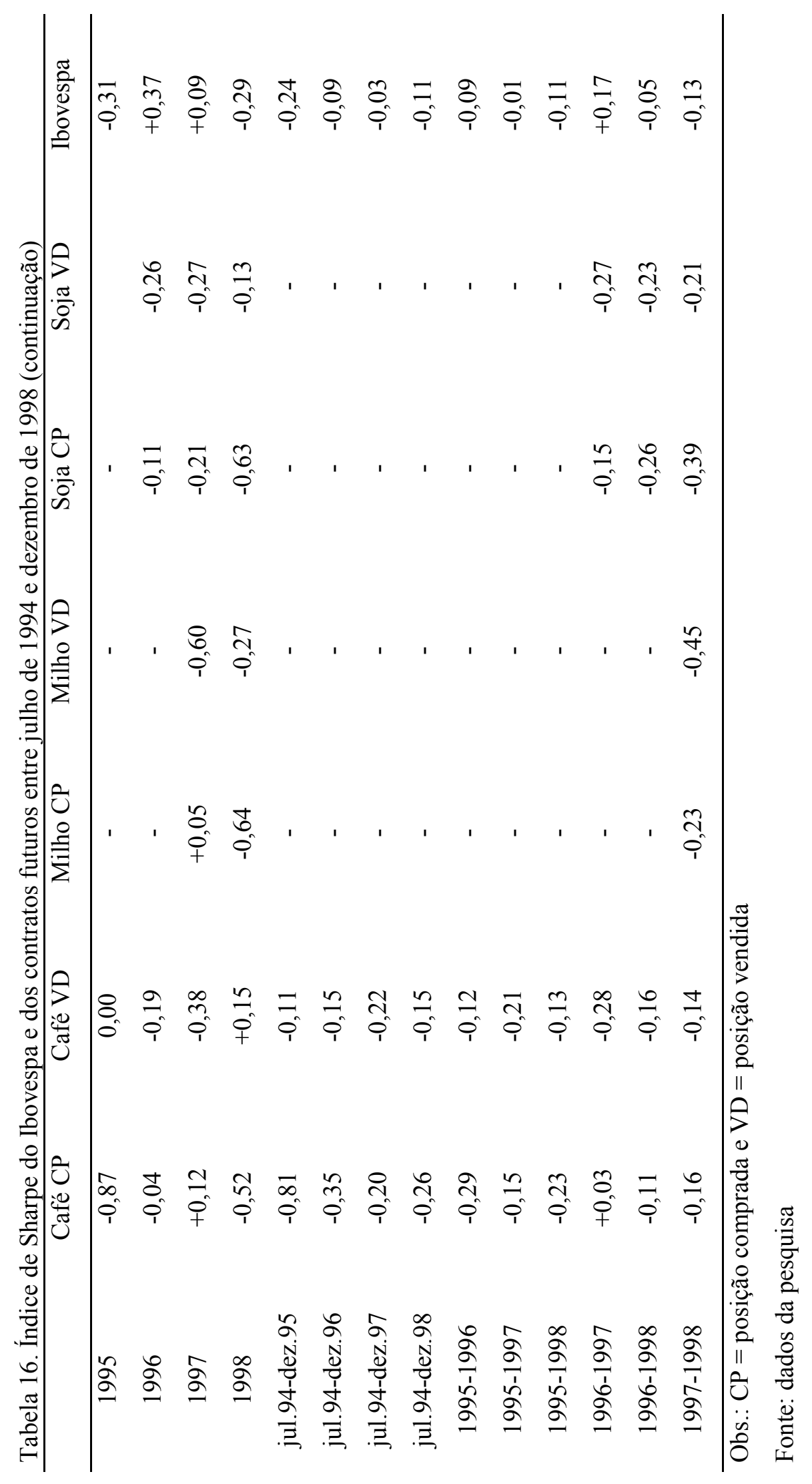


Em outras palavras, o histórico recente mostrou que os contratos futuros agropecuários apresentam poucos atrativos como alternativas isoladas de investimento. Talvez este seja um dos motivos pelos quais estes ativos ainda são pouco negociados no mercado financeiro brasileiro. No entanto, isso não significa que os contratos futuros não possam ser utilizados em estratégias de diversificação de investimentos, conforme será discutido nas próximas seções.

\section{2 - Verificação da correlação entre os retornos de ações e contratos futuros agropecuários}

O cálculo dos coeficientes de correlação amostrais entre os retornos do Ibovespa e de cada um dos contratos futuros agropecuários mostraram valores sempre próximos a zero, sugerindo que haveria uma correlação muito pequena entre eles. Porém, como lembra Hoel (1971), pode-se obter estimativas bastante distorcidas do verdadeiro valor da correlação ao considerar-se apenas uma amostra da população total. Fez-se então necessário verificar estatisticamente o valor destes coeficientes. Para tanto, assumiu-se a hipótese nula de que não haveria correlação entre os retornos (ou seja, coeficiente de correlação igual a zero) e a hipótese alternativa de que haveria correlação entre eles (ou seja, coeficiente de correlação diferente de zero).

$$
H_{0}: \rho=0 \quad H_{A}: \rho \neq 0
$$

A hipótese nula não pode ser rejeitada se o t calculado for menor que o $t$ crítico (tabelado). Adotando um nível de significância igual a 0,01 , os valores calculados de $\mathrm{t}$ são inferiores aos tabelados para todos os contratos futuros. Assim, os resultados não permitem rejeitar a hipótese nula de inexistência de correlação entre os retornos do Ibovespa e de cada um dos contratos futuros agropecuários negociados na BM\&F (Tabelas 17 e 18). 
Portanto, pode-se aceitar que o coeficiente de correlação entre os retornos do Ibovespa e de cada um dos seis contratos futuros agropecuários é igual a zero, sinalizando a viabilidade de uma estratégia de diversificação científica de investimentos por meio da combinação de ações (representadas pelo Ibovespa) e um contrato futuro agropecuário. Mais uma vez, vale lembrar que tal estratégia seria viável para qualquer valor diferente de 1 do coeficiente de correlação.

Tabela 17. Teste da hipótese de correlação nula entre os retornos do Ibovespa e dos contratos futuros de açúcar, algodão e boi gordo.

\begin{tabular}{lcccccc}
\hline & \multicolumn{2}{c}{ Açúcar $^{(1)}$} & \multicolumn{2}{c}{ Algodão } & \multicolumn{2}{c}{ Boi gordo $^{(2)}$} \\
& $\mathrm{CP}$ & $\mathrm{VD}$ & $\mathrm{CP}$ & $\mathrm{VD}$ & $\mathrm{CP}$ & $\mathrm{VD}$ \\
\hline Coeficiente de & $-0,16$ & $+0,16$ & $+0,01$ & $-0,01$ & $+0,07$ & $-0,07$ \\
correlação amostral & & & & & & \\
Observações & 39 & 39 & 25 & 25 & 54 & 54 \\
Graus de liberdade & 37 & 37 & 23 & 23 & 52 & 52 \\
t calculado & $-0,99$ & $-0,99$ & $+0,03$ & $-0,03$ & $+0,52$ & $-0,52$ \\
t crítico (0,01 signif.) & $+2,70$ & $+2,70$ & $+2,81$ & $+2,81$ & $+2,66$ & $+2,66$ \\
Hipótese aceita & $\mathrm{H}_{0}$ & $\mathrm{H}_{0}$ & $\mathrm{H}_{0}$ & $\mathrm{H}_{0}$ & $\mathrm{H}_{0}$ & $\mathrm{H}_{0}$ \\
\hline
\end{tabular}

Fonte: dados da pesquisa.

CP: posição comprada; VD: posição vendida

(1) t crítico calculado para 40 graus de liberdade;

(2) t crítico calculado para 60 graus de liberdade

Tabela 18. Teste da hipótese de correlação nula entre os retornos do Ibovespa e dos contratos futuros de café, milho e soja.

\begin{tabular}{lcccccc}
\hline & \multicolumn{2}{c}{ Café $^{(2)}$} & \multicolumn{2}{c}{ Milho } & \multicolumn{2}{c}{ Soja $^{(1)}$} \\
& $\mathrm{CP}$ & $\mathrm{VD}$ & $\mathrm{CP}$ & $\mathrm{VD}$ & $\mathrm{CP}$ & $\mathrm{VD}$ \\
\hline Coeficiente de & $+0,15$ & $-0,15$ & $-0,09$ & $+0,09$ & $-0,05$ & $+0,05$ \\
correlação amostral & & & & & & \\
Observações & 54 & 54 & 25 & 25 & 38 & 38 \\
Graus de liberdade & 52 & 52 & 23 & 23 & 36 & 36 \\
t calculado & $+1,10$ & $-1,10$ & $-0,48$ & $+0,48$ & $-0,28$ & $+0,28$ \\
t crítico (0,01 signif.) & $+2,66$ & $+2,66$ & $+2,81$ & $+2,81$ & $+2,70$ & $+2,70$ \\
Hipótese aceita & $\mathrm{H}_{0}$ & $\mathrm{H}_{0}$ & $\mathrm{H}_{0}$ & $\mathrm{H}_{0}$ & $\mathrm{H}_{0}$ & $\mathrm{H}_{0}$ \\
\hline
\end{tabular}

Fonte: dados da pesquisa.

CP: posição comprada; VD: posição vendida

(1) t crítico calculado para 40 graus de liberdade

(2) t crítico calculado para 60 graus de liberdade 


\section{3 - Comparação dos desempenhos de uma carteira composta por ações e de outra composta por ações e um contrato futuro agropecuário}

A terceira etapa de verificações empíricas consistiu em analisar o que ocorria com o retorno e o risco de uma carteira de ações quando um contrato futuro é incluído na carteira. Considerou-se inicialmente uma carteira cuja participação do Ibovespa era de 100\%. Em seguida foi incluído um contrato futuro com participação de $1 \%$ na carteira, ficando o Ibovespa com 99\% de participação. A participação do contrato futuro foi crescendo progressivamente $(2 \%, 3 \%, 4 \%$ etc. $)$, enquanto a do Ibovespa era reduzida no mesmo ritmo.

O resultado em todas as situações analisadas foi que carteiras combinando ações e títulos apresentavam retorno e risco menores que carteiras contendo apenas ações. Em 75\% das situações analisadas, a alocação que proporcionou maior retorno foi aquela com todos os recursos investidos em ações (Tabelas 19 a 24).

Com relação ao efeito de redução de risco, houve apenas duas exceções, que foram as inclusões de posições compradas em algodão em 1997 e de posições compradas em café em 1996. Todas as demais situações consideradas apontaram redução no risco das carteiras

combinando futuros e ações, ou seja, verificou-se esse comportamento em $98 \%$ dos casos analisados.

Como tanto retorno quanto risco eram reduzidos com a inclusão de contratos futuros nas carteiras de investimento, a questão foi então deslocada para outra esfera, ou seja, tornou-se necessário avaliar se a redução do risco da carteira foi suficiente para compensar a perda em termos de retorno. Para tanto utilizou-se o Índice de Sharpe, que mede o retorno ganho por unidade de risco assumida.

Em 73\% das situações analisadas, as carteiras que apresentaram valores mais elevados para o Índice de Sharpe foram aquelas compostas apenas por ações. Isso significa que a inclusão de contratos futuros em carteiras de ações tende a reduzir seu Índice de Sharpe. Em outras 
palavras, na maioria dos casos não seria possível afirmar que a redução do risco foi suficiente para compensar a perda de retorno da carteira. Por outro lado, vale destacar que as carteiras compostas por ações e contratos futuros apresentaram Índice de Sharpe superior ao das carteiras formadas apenas por ações em $37 \%$ dos casos analisados.

Neste ponto deve-se fazer uma ressalva. Conforme discutido anteriormente, o Índice de Sharpe pode levar a conclusões distorcidas quando o retorno do ativo em questão é negativo ou inferior à taxa de juros livre de risco. Como exemplo, pode-se considerar o caso da carteira formada por ações e contratos futuros de algodão em 1998.

Naquele ano, os retornos médios de posições compradas em algodão, de posições vendidas em algodão e do Ibovespa foram, respectivamente, de $-0,28 \%,+0,28 \%$ e $-3,39 \%$. Os riscos destes ativos no período foram de 4,33\% para os contratos futuros e de 19,26\% para o Ibovespa. A simples observação destes números sugeriria a opção pelos contratos futuros de algodão, que apresentaram retornos superiores e risco inferior ao Ibovespa. No entanto, o Índice de Sharpe apontou o Ibovespa como melhor alternativa.

Situações como essa ocorreram apenas em poucos casos analisados, ou seja, pode-se dizer que esse problema não compromete as conclusões gerais deste trabalho. Portanto, por meio do exercício realizado nesta etapa foi possível verificar que, na maioria dos casos, a inclusão de contratos futuros agropecuários efetivamente reduzia o risco das carteiras de ações, mas não o suficiente para compensar a perda de retorno decorrente desta estratégia.

Tabela 19. Características de um conjunto de carteiras representando diversas combinações de ações e contratos futuros de açúcar 


\begin{tabular}{|c|c|c|c|c|}
\hline Período & $\begin{array}{c}\text { Posição em } \\
\text { contratos } \\
\text { futuros } \\
\end{array}$ & $\begin{array}{c}\text { Alocação que } \\
\text { proporciona maior } \\
\text { retorno } \\
\end{array}$ & $\begin{array}{c}\text { Alocação que } \\
\text { proporciona menor } \\
\text { risco } \\
\end{array}$ & $\begin{array}{c}\text { Alocação que } \\
\text { proporciona maior } \\
\text { Índice de Sharpe }\end{array}$ \\
\hline \multirow[t]{2}{*}{1996} & Comprada & 100\% Ibovespa & $\begin{array}{l}\text { 69\% Ibovespa } \\
31 \% \text { açúcar }\end{array}$ & $100 \%$ Ibovespa \\
\hline & Vendida & $100 \%$ Ibovespa & $\begin{array}{l}\text { 75\% Ibovespa } \\
25 \% \text { açúcar }\end{array}$ & $100 \%$ Ibovespa \\
\hline \multirow[t]{2}{*}{1997} & Comprada & $100 \%$ Ibovespa & $\begin{array}{l}\text { 35\% Ibovespa } \\
65 \% \text { açúcar }\end{array}$ & $100 \%$ Ibovespa \\
\hline & Vendida & $100 \%$ Ibovespa & $\begin{array}{c}\text { 13\% Ibovespa } \\
87 \% \text { açúcar }\end{array}$ & $100 \%$ Ibovespa \\
\hline \multirow[t]{2}{*}{1998} & Comprada & Todas & $\begin{array}{c}29 \% \text { Ibovespa } \\
71 \% \text { açúcar }\end{array}$ & $100 \%$ Ibovespa \\
\hline & Vendida & 100\% açúcar & $\begin{array}{l}\text { 26\% Ibovespa } \\
74 \% \text { açúcar }\end{array}$ & 100\% açúcar \\
\hline \multirow[t]{2}{*}{$1996-97$} & Comprada & $100 \%$ Ibovespa & $\begin{array}{l}\text { 45\% Ibovespa } \\
55 \% \text { açúcar }\end{array}$ & $\begin{array}{l}78 \% \text { Ibovespa } \\
22 \% \text { açúcar }\end{array}$ \\
\hline & Vendida & 100\% Ibovespa & $\begin{array}{l}\text { 39\% Ibovespa } \\
61 \% \text { açúcar }\end{array}$ & 100\% Ibovespa \\
\hline \multirow[t]{2}{*}{$1996-98$} & Comprada & $100 \%$ Ibovespa & $\begin{array}{c}35 \% \text { Ibovespa } \\
65 \% \text { açúcar }\end{array}$ & $100 \%$ Ibovespa \\
\hline & Vendida & 100\% açúcar & $\begin{array}{l}\text { 29\% Ibovespa } \\
71 \% \text { açúcar }\end{array}$ & $\begin{array}{l}\text { 27\% Ibovespa } \\
73 \% \text { açúcar }\end{array}$ \\
\hline \multirow[t]{2}{*}{$1997-98$} & Comprada & $100 \%$ Ibovespa & $\begin{array}{c}31 \% \text { Ibovespa } \\
69 \% \text { açúcar }\end{array}$ & $100 \%$ Ibovespa \\
\hline & Vendida & 100\% açúcar & $\begin{array}{l}\text { 23\% Ibovespa } \\
77 \% \text { açúcar }\end{array}$ & 100\% açúcar \\
\hline
\end{tabular}

Fonte: dados da pesquisa. 
Tabela 20. Características de um conjunto de carteiras representando diversas combinações de ações e contratos futuros de algodão

\begin{tabular}{|c|c|c|c|c|}
\hline Período & $\begin{array}{l}\text { Posição em } \\
\text { contratos } \\
\text { futuros } \\
\end{array}$ & $\begin{array}{c}\text { Alocação que } \\
\text { proporciona } \\
\text { máximo retorno }\end{array}$ & $\begin{array}{l}\text { Alocação que } \\
\text { proporciona } \\
\text { mínimo risco }\end{array}$ & $\begin{array}{c}\text { Alocação que } \\
\text { proporciona maior } \\
\text { Índice de Sharpe }\end{array}$ \\
\hline \multirow[t]{2}{*}{1997} & Comprada & 100\% Ibovespa & $100 \%$ algodão & 100\% Ibovespa \\
\hline & Vendida & 100\% Ibovespa & $\begin{array}{l}11 \% \text { Ibovespa } \\
89 \% \text { algodão }\end{array}$ & 100\% Ibovespa \\
\hline \multirow[t]{2}{*}{1998} & Comprada & $100 \%$ algodão & $\begin{array}{l}\text { 7\% Ibovespa } \\
93 \% \text { algodão }\end{array}$ & $100 \%$ Ibovespa \\
\hline & Vendida & $100 \%$ algodão & $\begin{array}{l}\text { 3\% Ibovespa } \\
97 \% \text { algodão }\end{array}$ & 100\% Ibovespa \\
\hline \multirow[t]{2}{*}{$1997-98$} & Comprada & 100\% Ibovespa & $\begin{array}{l}5 \% \text { Ibovespa } \\
95 \% \text { algodão }\end{array}$ & 100\% Ibovespa \\
\hline & Vendida & $100 \%$ algodão & $\begin{array}{l}5 \% \text { Ibovespa } \\
95 \% \text { algodão }\end{array}$ & $100 \%$ algodão \\
\hline
\end{tabular}

Fonte: dados da pesquisa. 
Tabela 21. Características de um conjunto de carteiras representando diversas combinações de ações e contratos futuros de boi gordo

\begin{tabular}{|c|c|c|c|c|}
\hline Período & $\begin{array}{l}\text { Posição em } \\
\text { contratos } \\
\text { futuros }\end{array}$ & $\begin{array}{c}\text { Alocação que } \\
\text { proporciona maior } \\
\text { retorno }\end{array}$ & $\begin{array}{c}\text { Alocação que } \\
\text { proporciona menor } \\
\text { risco }\end{array}$ & $\begin{array}{c}\text { Alocação que } \\
\text { proporciona maior } \\
\text { Índice de Sharpe }\end{array}$ \\
\hline \multirow[t]{2}{*}{1995} & Comprada & $100 \%$ Ibovespa & $\begin{array}{l}43 \% \text { Ibovespa } \\
57 \% \text { boi gordo }\end{array}$ & $100 \%$ Ibovespa \\
\hline & Vendida & $100 \%$ boi gordo & $\begin{array}{l}42 \% \text { Ibovespa } \\
58 \% \text { boi gordo }\end{array}$ & $100 \%$ boi gordo \\
\hline \multirow[t]{2}{*}{1996} & Comprada & $100 \%$ Ibovespa & $\begin{array}{l}55 \% \text { Ibovespa } \\
45 \% \text { boi gordo }\end{array}$ & $100 \%$ Ibovespa \\
\hline & Vendida & 100\% Ibovespa & $\begin{array}{l}52 \% \text { Ibovespa } \\
48 \% \text { boi gordo }\end{array}$ & $100 \%$ Ibovespa \\
\hline \multirow[t]{2}{*}{1997} & Comprada & $100 \%$ Ibovespa & $\begin{array}{l}17 \% \text { Ibovespa } \\
83 \% \text { boi gordo }\end{array}$ & $100 \%$ Ibovespa \\
\hline & Vendida & $100 \%$ Ibovespa & $\begin{array}{l}23 \% \text { Ibovespa } \\
77 \% \text { boi gordo }\end{array}$ & $100 \%$ Ibovespa \\
\hline \multirow[t]{2}{*}{1998} & Comprada & $100 \%$ boi gordo & $\begin{array}{l}1 \% \text { Ibovespa } \\
99 \% \text { boi gordo }\end{array}$ & $100 \%$ Ibovespa \\
\hline & Vendida & $100 \%$ boi gordo & $\begin{array}{l}2 \% \text { Ibovespa } \\
98 \% \text { boi gordo }\end{array}$ & $100 \%$ Ibovespa \\
\hline \multirow[t]{2}{*}{$\begin{array}{c}\text { jul.94 a } \\
\text { dez.95 }\end{array}$} & Comprada & $100 \%$ Ibovespa & $\begin{array}{l}63 \% \text { Ibovespa } \\
37 \% \text { boi gordo }\end{array}$ & $100 \%$ Ibovespa \\
\hline & Vendida & $100 \%$ boi gordo & $\begin{array}{l}62 \% \text { Ibovespa } \\
38 \% \text { boi gordo }\end{array}$ & $100 \%$ boi gordo \\
\hline \multirow[t]{2}{*}{$\begin{array}{c}\text { jul.94 a } \\
\text { dez.96 }\end{array}$} & Comprada & $100 \%$ Ibovespa & $\begin{array}{l}62 \% \text { Ibovespa } \\
38 \% \text { boi gordo }\end{array}$ & $100 \%$ Ibovespa \\
\hline & Vendida & $100 \%$ Ibovespa & $\begin{array}{l}60 \% \text { Ibovespa } \\
40 \% \text { boi gordo }\end{array}$ & $100 \%$ Ibovespa \\
\hline \multirow[t]{2}{*}{$\begin{array}{c}\text { jul.94 a } \\
\text { dez.97 }\end{array}$} & Comprada & $100 \%$ Ibovespa & $\begin{array}{l}53 \% \text { Ibovespa } \\
47 \% \text { boi gordo }\end{array}$ & $100 \%$ Ibovespa \\
\hline & Vendida & $100 \%$ Ibovespa & $\begin{array}{l}52 \% \text { Ibovespa } \\
48 \% \text { boi gordo }\end{array}$ & $100 \%$ Ibovespa \\
\hline \multirow[t]{2}{*}{$\begin{array}{c}\text { jul.94 a } \\
\text { dez.98 }\end{array}$} & Comprada & $100 \%$ Ibovespa & $\begin{array}{l}36 \% \text { Ibovespa } \\
64 \% \text { boi gordo }\end{array}$ & $100 \%$ Ibovespa \\
\hline & Vendida & 100\% Ibovespa & $\begin{array}{l}37 \% \text { Ibovespa } \\
63 \% \text { boi gordo }\end{array}$ & 100\% Ibovespa \\
\hline
\end{tabular}

(continua) 
Tabela 21. Características de um conjunto de carteiras representando diversas combinações de ações e contratos futuros de boi gordo (continuação)

\begin{tabular}{|c|c|c|c|c|}
\hline Período & $\begin{array}{c}\text { Posição em } \\
\text { contratos } \\
\text { futuros } \\
\end{array}$ & $\begin{array}{c}\text { Alocação que } \\
\text { proporciona maior } \\
\text { retorno }\end{array}$ & $\begin{array}{c}\text { Alocação que } \\
\text { proporciona menor } \\
\text { risco } \\
\end{array}$ & $\begin{array}{c}\text { Alocação que } \\
\text { proporciona maior } \\
\text { Índice de Sharpe }\end{array}$ \\
\hline \multirow[t]{2}{*}{$1995-96$} & Comprada & $100 \%$ Ibovespa & $\begin{array}{l}44 \% \text { Ibovespa } \\
56 \% \text { boi gordo }\end{array}$ & $100 \%$ Ibovespa \\
\hline & Vendida & $100 \%$ Ibovespa & $\begin{array}{l}45 \% \text { Ibovespa } \\
55 \% \text { boi gordo }\end{array}$ & $100 \%$ Ibovespa \\
\hline \multirow[t]{2}{*}{$1995-97$} & Comprada & $100 \%$ Ibovespa & $\begin{array}{l}34 \% \text { Ibovespa } \\
66 \% \text { boi gordo }\end{array}$ & $100 \%$ Ibovespa \\
\hline & Vendida & $100 \%$ Ibovespa & $\begin{array}{l}37 \% \text { Ibovespa } \\
63 \% \text { boi gordo }\end{array}$ & $100 \%$ Ibovespa \\
\hline \multirow[t]{2}{*}{$1995-98$} & Comprada & $100 \%$ Ibovespa & $\begin{array}{l}19 \% \text { Ibovespa } \\
81 \% \text { boi gordo }\end{array}$ & $100 \%$ Ibovespa \\
\hline & Vendida & $100 \%$ Ibovespa & $\begin{array}{l}23 \% \text { Ibovespa } \\
77 \% \text { boi gordo }\end{array}$ & $100 \%$ Ibovespa \\
\hline \multirow[t]{2}{*}{$1996-97$} & Comprada & $100 \%$ Ibovespa & $\begin{array}{l}24 \% \text { Ibovespa } \\
76 \% \text { boi gordo }\end{array}$ & $\begin{array}{l}73 \% \text { Ibovespa } \\
27 \% \text { boi gordo }\end{array}$ \\
\hline & Vendida & $100 \%$ Ibovespa & $\begin{array}{l}32 \% \text { Ibovespa } \\
68 \% \text { boi gordo }\end{array}$ & $100 \%$ Ibovespa \\
\hline \multirow[t]{2}{*}{$1996-98$} & Comprada & $100 \%$ Ibovespa & $\begin{array}{l}9 \% \text { Ibovespa } \\
91 \% \text { boi gordo }\end{array}$ & $\begin{array}{l}24 \% \text { Ibovespa } \\
76 \% \text { boi gordo }\end{array}$ \\
\hline & Vendida & $100 \%$ Ibovespa & $\begin{array}{l}16 \% \text { Ibovespa } \\
84 \% \text { boi gordo }\end{array}$ & $100 \%$ Ibovespa \\
\hline \multirow[t]{2}{*}{$1997-98$} & Comprada & $100 \%$ boi gordo & $\begin{array}{l}6 \% \text { Ibovespa } \\
94 \% \text { boi gordo }\end{array}$ & $100 \%$ boi gordo \\
\hline & Vendida & $100 \%$ Ibovespa & $\begin{array}{l}11 \% \text { Ibovespa } \\
89 \% \text { boi gordo }\end{array}$ & 100\% Ibovespa \\
\hline
\end{tabular}

Fonte: dados da pesquisa. 
Tabela 22. Características de um conjunto de carteiras representando diversas combinações de ações e contratos futuros de café

\begin{tabular}{|c|c|c|c|c|}
\hline Período & $\begin{array}{l}\text { Posição em } \\
\text { contratos } \\
\text { futuros }\end{array}$ & $\begin{array}{c}\text { Alocação que } \\
\text { proporciona maior } \\
\text { retorno }\end{array}$ & $\begin{array}{c}\text { Alocação que } \\
\text { proporciona menor } \\
\text { risco }\end{array}$ & $\begin{array}{c}\text { Alocação que } \\
\text { proporciona maior } \\
\text { Índice de Sharpe }\end{array}$ \\
\hline \multirow[t]{2}{*}{1995} & Comprada & 100\% Ibovespa & $\begin{array}{c}35 \% \text { Ibovespa } \\
65 \% \text { café }\end{array}$ & 100\% Ibovespa \\
\hline & Vendida & $100 \%$ café & $\begin{array}{l}29 \% \text { Ibovespa } \\
71 \% \text { café }\end{array}$ & $100 \%$ café \\
\hline \multirow[t]{2}{*}{1996} & Comprada & 100\% Ibovespa & $100 \%$ Ibovespa & 100\% Ibovespa \\
\hline & Vendida & 100\% Ibovespa & $\begin{array}{l}81 \% \text { Ibovespa } \\
19 \% \text { café }\end{array}$ & $\begin{array}{c}99 \% \text { Ibovespa } \\
1 \% \text { café }\end{array}$ \\
\hline \multirow[t]{2}{*}{1997} & Comprada & $100 \%$ café & $\begin{array}{c}56 \% \text { Ibovespa } \\
44 \% \text { café }\end{array}$ & $\begin{array}{c}47 \% \text { Ibovespa } \\
53 \% \text { café }\end{array}$ \\
\hline & Vendida & 100\% Ibovespa & $\begin{array}{l}55 \% \text { Ibovespa } \\
45 \% \text { café }\end{array}$ & 100\% Ibovespa \\
\hline \multirow[t]{2}{*}{1998} & Comprada & $100 \%$ Ibovespa & $\begin{array}{c}25 \% \text { Ibovespa } \\
75 \% \text { café }\end{array}$ & 100\% Ibovespa \\
\hline & Vendida & $100 \%$ café & $\begin{array}{l}27 \% \text { Ibovespa } \\
73 \% \text { café }\end{array}$ & $100 \%$ café \\
\hline \multirow[t]{2}{*}{$\begin{array}{c}\text { jul.94 a } \\
\text { dez.95 }\end{array}$} & Comprada & $100 \%$ Ibovespa & $\begin{array}{c}31 \% \text { Ibovespa } \\
69 \% \text { café }\end{array}$ & 100\% Ibovespa \\
\hline & Vendida & $100 \%$ café & $\begin{array}{l}33 \% \text { Ibovespa } \\
67 \% \text { café }\end{array}$ & $100 \%$ café \\
\hline \multirow[t]{2}{*}{$\begin{array}{l}\text { jul.94 a } \\
\text { dez.96 }\end{array}$} & Comprada & $100 \%$ Ibovespa & $\begin{array}{c}64 \% \text { Ibovespa } \\
36 \% \text { café }\end{array}$ & 100\% Ibovespa \\
\hline & Vendida & 100\% Ibovespa & $\begin{array}{c}59 \% \text { Ibovespa } \\
41 \% \text { café }\end{array}$ & 100\% Ibovespa \\
\hline \multirow[t]{2}{*}{$\begin{array}{c}\text { jul.94 a } \\
\text { dez.97 }\end{array}$} & Comprada & $100 \%$ Ibovespa & $\begin{array}{c}62 \% \text { Ibovespa } \\
38 \% \text { café }\end{array}$ & $100 \%$ Ibovespa \\
\hline & Vendida & 100\% Ibovespa & $\begin{array}{c}59 \% \text { Ibovespa } \\
41 \% \text { café }\end{array}$ & 100\% Ibovespa \\
\hline \multirow[t]{2}{*}{$\begin{array}{l}\text { jul.94 a } \\
\text { dez.98 }\end{array}$} & Comprada & 100\% Ibovespa & $\begin{array}{c}49 \% \text { Ibovespa } \\
51 \% \text { café }\end{array}$ & 100\% Ibovespa \\
\hline & Vendida & 100\% Ibovespa & $\begin{array}{c}49 \% \text { Ibovespa } \\
51 \% \text { café }\end{array}$ & $\begin{array}{c}\text { 100\% Ibovespa } \\
\text { (continua) }\end{array}$ \\
\hline
\end{tabular}


Tabela 22. Características de um conjunto de carteiras representando diversas combinações de ações e contratos futuros de café (continuação)

\begin{tabular}{|c|c|c|c|c|}
\hline Período & $\begin{array}{l}\text { Posição em } \\
\text { contratos } \\
\text { futuros } \\
\end{array}$ & $\begin{array}{c}\text { Alocação que } \\
\text { proporciona maior } \\
\text { retorno }\end{array}$ & $\begin{array}{c}\text { Alocação que } \\
\text { proporciona menor } \\
\text { risco }\end{array}$ & $\begin{array}{c}\text { Alocação que } \\
\text { proporciona maior } \\
\text { Índice de Sharpe }\end{array}$ \\
\hline \multirow[t]{2}{*}{$1995-96$} & Comprada & $100 \%$ Ibovespa & $\begin{array}{c}71 \% \text { Ibovespa } \\
29 \% \text { café }\end{array}$ & 100\% Ibovespa \\
\hline & Vendida & 100\% Ibovespa & $\begin{array}{c}65 \% \text { Ibovespa } \\
35 \% \text { café }\end{array}$ & $100 \%$ Ibovespa \\
\hline \multirow[t]{2}{*}{$1995-97$} & Comprada & $100 \%$ Ibovespa & $\begin{array}{c}65 \% \text { Ibovespa } \\
35 \% \text { café }\end{array}$ & $100 \%$ Ibovespa \\
\hline & Vendida & $100 \%$ Ibovespa & $\begin{array}{c}62 \% \text { Ibovespa } \\
38 \% \text { café }\end{array}$ & $100 \%$ Ibovespa \\
\hline \multirow[t]{2}{*}{$1995-98$} & Comprada & 100\% Ibovespa & $\begin{array}{c}51 \% \text { Ibovespa } \\
49 \% \text { café }\end{array}$ & $100 \%$ Ibovespa \\
\hline & Vendida & $100 \%$ Ibovespa & $\begin{array}{c}50 \% \text { Ibovespa } \\
50 \% \text { café }\end{array}$ & $100 \%$ Ibovespa \\
\hline \multirow[t]{2}{*}{$1996-97$} & Comprada & 100\% Ibovespa & $\begin{array}{l}77 \% \text { Ibovespa } \\
23 \% \text { café }\end{array}$ & $\begin{array}{c}87 \% \text { Ibovespa } \\
13 \% \text { café }\end{array}$ \\
\hline & Vendida & $100 \%$ Ibovespa & $\begin{array}{c}69 \% \text { Ibovespa } \\
31 \% \text { café }\end{array}$ & $100 \%$ Ibovespa \\
\hline \multirow[t]{2}{*}{$1996-98$} & Comprada & 100\% Ibovespa & $\begin{array}{c}53 \% \text { Ibovespa } \\
47 \% \text { café }\end{array}$ & $\begin{array}{c}91 \% \text { Ibovespa } \\
9 \% \text { café }\end{array}$ \\
\hline & Vendida & $100 \%$ Ibovespa & $\begin{array}{c}52 \% \text { Ibovespa } \\
48 \% \text { café }\end{array}$ & $100 \%$ Ibovespa \\
\hline \multirow[t]{2}{*}{$1997-98$} & Comprada & $100 \%$ café & $\begin{array}{c}39 \% \text { Ibovespa } \\
61 \% \text { café }\end{array}$ & $100 \%$ café \\
\hline & Vendida & $100 \%$ Ibovespa & $\begin{array}{c}41 \% \text { Ibovespa } \\
59 \% \text { café }\end{array}$ & $100 \%$ Ibovespa \\
\hline
\end{tabular}

Fonte: dados da pesquisa. 
Tabela 23. Características de um conjunto de carteiras representando diversas combinações de ações e contratos futuros de milho

\begin{tabular}{|c|c|c|c|c|}
\hline Período & $\begin{array}{l}\text { Posição em } \\
\text { contratos } \\
\text { futuros } \\
\end{array}$ & $\begin{array}{c}\text { Alocação que } \\
\text { proporciona } \\
\text { máximo retorno }\end{array}$ & $\begin{array}{l}\text { Alocação que } \\
\text { proporciona } \\
\text { mínimo risco }\end{array}$ & $\begin{array}{c}\text { Alocação que } \\
\text { proporciona maior } \\
\text { Índice de Sharpe }\end{array}$ \\
\hline \multirow[t]{2}{*}{1997} & Comprada & 100\% Ibovespa & $\begin{array}{c}23 \% \text { Ibovespa } \\
77 \% \text { milho }\end{array}$ & $\begin{array}{l}\text { 49\% Ibovespa } \\
51 \% \text { milho }\end{array}$ \\
\hline & Vendida & 100\% Ibovespa & $\begin{array}{l}\text { 19\% Ibovespa } \\
81 \% \text { milho }\end{array}$ & 100\% Ibovespa \\
\hline \multirow[t]{2}{*}{1998} & Comprada & $100 \%$ milho & $\begin{array}{l}\text { 9\% Ibovespa } \\
91 \% \text { milho }\end{array}$ & $100 \%$ Ibovespa \\
\hline & Vendida & $100 \%$ milho & $\begin{array}{l}\text { 1\% Ibovespa } \\
99 \% \text { milho }\end{array}$ & $100 \%$ milho \\
\hline \multirow[t]{2}{*}{$1997-98$} & Comprada & $100 \%$ milho & $\begin{array}{l}13 \% \text { Ibovespa } \\
87 \% \text { milho }\end{array}$ & $100 \%$ milho \\
\hline & Vendida & $100 \%$ Ibovespa & $\begin{array}{l}\text { 9\% Ibovespa } \\
91 \% \text { milho }\end{array}$ & $100 \%$ Ibovespa \\
\hline
\end{tabular}

Fonte: dados da pesquisa. 
Tabela 24. Características de um conjunto de carteiras representando diversas combinações de ações e contratos futuros de soja

\begin{tabular}{|c|c|c|c|c|}
\hline Período & $\begin{array}{l}\text { Posição em } \\
\text { contratos } \\
\text { futuros } \\
\end{array}$ & $\begin{array}{c}\text { Alocação que } \\
\text { proporciona maior } \\
\text { retorno }\end{array}$ & $\begin{array}{c}\text { Alocação que } \\
\text { proporciona menor } \\
\text { risco }\end{array}$ & $\begin{array}{c}\text { Alocação que } \\
\text { proporciona maior } \\
\text { Índice de Sharpe }\end{array}$ \\
\hline \multirow[t]{2}{*}{1996} & Comprada & $100 \%$ Ibovespa & $\begin{array}{c}82 \% \text { Ibovespa } \\
18 \% \text { soja }\end{array}$ & $100 \%$ Ibovespa \\
\hline & Vendida & 100\% Ibovespa & $\begin{array}{c}77 \% \text { Ibovespa } \\
23 \% \text { soja }\end{array}$ & $100 \%$ Ibovespa \\
\hline \multirow[t]{2}{*}{1997} & Comprada & $100 \%$ Ibovespa & $\begin{array}{c}28 \% \text { Ibovespa } \\
72 \% \text { soja }\end{array}$ & $100 \%$ Ibovespa \\
\hline & Vendida & $100 \%$ Ibovespa & $\begin{array}{c}25 \% \text { Ibovespa } \\
75 \% \text { soja }\end{array}$ & $100 \%$ Ibovespa \\
\hline \multirow[t]{2}{*}{1998} & Comprada & $100 \%$ soja & $\begin{array}{c}12 \% \text { Ibovespa } \\
88 \% \text { soja }\end{array}$ & $100 \%$ Ibovespa \\
\hline & Vendida & $100 \%$ soja & $\begin{array}{c}2 \% \text { Ibovespa } \\
98 \% \text { soja }\end{array}$ & $100 \%$ soja \\
\hline \multirow[t]{2}{*}{$1996-97$} & Comprada & 100\% Ibovespa & $\begin{array}{c}48 \% \text { Ibovespa } \\
52 \% \text { soja }\end{array}$ & $\begin{array}{c}85 \% \text { Ibovespa } \\
15 \% \text { soja }\end{array}$ \\
\hline & Vendida & $100 \%$ Ibovespa & $\begin{array}{c}48 \% \text { Ibovespa } \\
52 \% \text { soja }\end{array}$ & $100 \%$ Ibovespa \\
\hline \multirow[t]{2}{*}{$1996-98$} & Comprada & $100 \%$ Ibovespa & $\begin{array}{c}27 \% \text { Ibovespa } \\
73 \% \text { soja }\end{array}$ & $100 \%$ Ibovespa \\
\hline & Vendida & $100 \%$ Ibovespa & $\begin{array}{l}25 \% \text { Ibovespa } \\
75 \% \text { soja }\end{array}$ & $\begin{array}{c}84 \% \text { Ibovespa } \\
16 \% \text { soja }\end{array}$ \\
\hline \multirow[t]{2}{*}{$1997-98$} & Comprada & $100 \%$ Ibovespa & $\begin{array}{c}17 \% \text { Ibovespa } \\
83 \% \text { soja }\end{array}$ & $100 \%$ Ibovespa \\
\hline & Vendida & $100 \%$ soja & $\begin{array}{c}11 \% \text { Ibovespa } \\
89 \% \text { soja }\end{array}$ & $100 \%$ soja \\
\hline
\end{tabular}

Fonte: dados da pesquisa. 


\section{4 - Verificação da viabilidade de se construir carteiras eficientes por meio da combinação de ações e contratos futuros agropecuários}

Nesta etapa procurou-se construir fronteiras eficientes com o Ibovespa e os seis contratos futuros agropecuários por meio do algoritmo desenvolvido por Markowitz (1959). A idéia básica era verificar se carteiras combinando ações e contratos futuros poderiam ser mais eficientes que carteiras compostas apenas por ações.

O período de julho de 1994 a dezembro de 1998 foi novamente dividido em vários subperíodos e foram testadas todas as combinações possíveis entre o Ibovespa e as posições compradas e vendidas em todos os seis contratos futuros agropecuários. No total, tentou-se construir 272 fronteiras eficientes e houve sucesso em 230 tentativas (para as demais não foi possível encontrar uma solução por meio do algoritmo de Markowitz).

Entre as 230 fronteiras eficientes construídas, 114 mostraram carteiras combinadas mais eficientes que o Ibovespa. Isso sugere que houve possibilidades de formar carteiras diversificadas que apresentassem, pelo menos, retorno superior e risco igual ao do Ibovespa ou então risco inferior e retorno igual ao do Ibovespa.

Por exemplo, uma carteira composta por posições compradas em boi gordo (participação de 28,640\%), posições compradas em café $(38,785 \%)$, posições vendidas em milho $(6,141 \%)$ e Ibovespa (26,434\%) em 1997 teria obtido retorno médio de 3,1\%, ou seja, o mesmo do Ibovespa. Porém, o risco desta carteira teria sido de 6,9\%, contra 12,4\% do Ibovespa.

No mesmo período, uma carteira composta por posições compradas em café (participação de $85,984 \%)$ e Ibovespa (14,016\%) teria registrado risco de $12,4 \%$, ou seja, o mesmo do Ibovespa. No entanto, o retorno médio desta carteira teria sido de 5,2\%, contra 3,1\% do Ibovespa. 
Da mesma forma, uma carteira com posições compradas em boi gordo (participação de 13,428\%), posições compradas em café (49,251\%) e Ibovespa (37,321\%) apresentaria retorno médio de 1,3\% entre janeiro de 1996 e dezembro de 1998, ou seja, o mesmo retorno médio do Ibovespa no período. Por outro lado, o risco da carteira combinada seria de 9,4\%, inferior aos 13,6\% do Ibovespa.

Ainda neste mesmo período, uma carteira formada pelo Ibovespa (participação de 3,787\%) e posições compradas em café $(96,213 \%)$ teria apresentado o mesmo risco do Ibovespa, ou seja, $13,6 \%$. Porém, o retorno médio da carteira teria sido de $1,6 \%$, contra $1,3 \%$ do Ibovespa.

No entanto, deve-se lembrar que estas carteiras combinadas mais eficientes que o Ibovespa não foram necessariamente as únicas alternativas de carteiras mais eficientes que o Ibovespa nos períodos analisados. Carteiras diversificadas com outros ativos poderiam ter sido formadas e também apresentar maior eficiência que uma carteira baseada no Ibovespa. Conforme discutido anteriormente, vale lembrar que o Ibovespa não pode ser considerado uma carteira eficiente (Nakamura, 1998).

A análise realizada neste trabalho limitou-se a comparar carteiras de investimentos compostas por ações e contratos futuros agropecuários e verificou que carteiras combinando estes ativos podem ser mais eficientes que carteiras formados apenas por ações (Ibovespa). Evidentemente essa constatação não exclui a possibilidade de haver outros ativos que não foram considerados neste trabalho e que também poderiam ser combinados a ações para formar carteiras mais eficientes que aquela representado pelo Ibovespa.

\section{5 - Considerações finais}


Os resultados dos experimentos realizados de acordo com a metodologia proposta permitiram chegar a duas constatações gerais sobre a viabilidade de incorporar contratos futuros agropecuários em carteiras de ações:

a) teoricamente existem vantagens em tal estratégia, visto que é possível aceitar a hipótese de que a correlação entre os retornos do Ibovespa e de cada um dos seis contratos futuros é nula; e

b) existem evidências empíricas capazes de comprovar as vantagens da combinação destes ativos em carteiras de investimentos, mas não de forma consistente ao longo do período analisado. 


\section{7 - CONCLUSÃO}

"There ain't no such thing as a free lunch". Robert A. Heinlein

O objetivo deste trabalho é analisar o potencial de utilização de contratos futuros agropecuários na composição de carteiras de investimento por meio da comparação entre carteiras compostas por ações e carteiras compostas por ações e contratos futuros no período entre julho de 1994 e dezembro de 1998.

Os resultados encontrados mostraram que, sob a ótica da Teoria do Portfólio, existe potencial para esta estratégia de carteiras combinadas. Isso porque não se pode rejeitar a hipótese de que existe correlação nula entre os retornos de ações e de contratos futuros agropecuários.

Verificou-se também que, para o período considerado, os contratos futuros agropecuários tomados individualmente não são boas alternativas de investimento se comparados ao Ibovespa. Porém, quando combinados com o Ibovespa em uma carteira de investimentos, estes contratos podem proporcionar benefícios para os investidores.

A análise de carteiras combinando o Ibovespa e um contrato futuro comprovou que essa estratégia poderia efetivamente reduzir o risco da carteira, embora essa redução não fosse suficiente para compensar a diminuição do seu retorno esperado.

Foi então analisada a possibilidade de existirem fronteiras eficientes combinando-se o Ibovespa com todos os seis contratos futuros considerados. Verificou-se que seria possível construir diversas carteiras mais eficientes que o Ibovespa com estas combinações durante o período em questão, embora estas não fossem necessariamente as mais eficientes que poderiam ser formadas no mercado financeiro. 
Portanto, este trabalho constatou que a inclusão de contratos futuros agropecuários em carteiras de ações tende efetivamente a reduzir seu risco. Em algumas situações, essa redução ocorre concomitantemente à redução do retorno esperado da carteira, enquanto em outros casos não há perda de retorno. Logo, pode-se dizer que esta estratégia deveria, pelo menos, ser considerada no processo de formação de carteiras de investimento.

Sendo possível verificar os benefícios da utilização de contratos futuros agropecuários em carteiras de ações, pode-se perguntar por que esta estratégia é pouco utilizada no mercado financeiro brasileiro. Embora este não seja um dos objetivos do presente trabalho, pode-se levantar alguns pontos para pesquisas futuras.

Um problema que pode prejudicar a utilização de contratos futuros agropecuários em carteiras de investimento é a baixa liquidez deste mercado. A pequena quantidade de negócios com futuros agropecuários traz dificuldades para a formação de preços e para a mobilidade dos investidores. Com poucos agentes atuando no mercado, os preços tornam-se mais sensíveis a movimentos específicos nos negócios. Além disso, um investidor sempre terá dúvidas quanto à existência ou não de agentes atuando no mercado quando quiser realizar algum negócio. Evidentemente estes dois eventos não são desejados por investidor algum no mercado financeiro.

Outro aspecto que pode prejudicar a demanda por contratos futuros agropecuários é a existência de muitos outros instrumentos financeiros capazes de oferecer benefícios semelhantes. Por exemplo, existem centenas de ações sendo negociadas no mercado brasileiro e pode-se formar carteiras mais eficientes que o Ibovespa com algumas delas (Nakamura, 1998). Por outro lado, existem apenas seis contratos futuros agropecuários no mercado brasileiro. Além disso, o mercado acionário é mais antigo e mais difundido no Brasil do que o mercado de futuros agropecuários. 
Por fim, algumas características específicas dos mercados futuros tornam este tipo de investimento mais complicado. Ao comprar uma ação, por exemplo, a grande preocupação do investidor é acompanhar seu preço e decidir o melhor momento de vendê-la. No caso do mercado de futuros, deve-se preocupar com as datas dos diferentes vencimentos e com os custos operacionais distintos daqueles existentes no mercado acionário.

Enfim, estas são apenas algumas possíveis explicações para a baixa demanda por contratos futuros agropecuários no mercado financeiro brasileiro. Uma análise mais completa e abrangente sobre o tema ficará a cargo de futuros trabalhos. 


\section{REFERÊNCIAS BIBLIOGRÁFICAS}

ALEXANDER, G. J.; FRANCIS, J. C. Portfolio analysis. 2.ed. Prentice-Hall, 1986. p.306.

ALLEN, M. Diversifying a typical investment portfolio with managed futures: country overviews. RXR Capital Asset Management, 1999.

BAWA, V.S.; CHAKRIN, L.M. Optimal portfolio choice and equilibrium in a lognormal securities market. In: ELTON, E.J.; GRUBER, M.J. (Ed.) Portfolio theory, 25 years after. North-Holland Publishing Company, 1979. p. 47-62.

BERNSTEIN, P.L. Against the gods: the remarkable history of risk. John Wiley \& Sons, 1996. p.383.

BODIE, Z.; ROSANSKY, V.I. Risk and return in commodity futures. In: PECK, A. E. (Ed.) Selected writings on futures markets: research directions in commodity markets, 1970-1980. Chicago: Board of Trade of the City of Chicago, 1984. Section 2, cap.5, p.159-176.

CHANCE, D.M. Managed futures and their role in investments portfolios. Charlottesville: The Research Foundation of the Institute of Chartered Financial Analysts, 1994. p.80.

DUARTE JÚNIOR, A.M. Análise da performance de investimentos. Resenha BM\&F, n.121, p.65-78, 1998 .

EDWARDS, F.R.; PARK, J.M. Do managed futures make good investments? The Journal of Futures Markets, v.16, n.5, p.475-517, 1996.

ELTON, E.J.; GRUBER, M.J. Modern portfolio theory and investment analysis. 5.ed. John Wiley \& Sons, 1995. p.715.

ELTON, E.J.; GRUBER, M.J.; RENTZLER, J. The performance of publicly offered commodity funds. Financial Analysts Journal, July/August, 1990.

HERBST, A.F.; McCORMACK, J.P. An examination of the risk-return characteristics of portfolios combining commodity futures contracts with common stocks. Center for the Study of Futures Markets, Columbia University, January 1986. Working paper. 
HERBST, A.F.; McCORMACK, J.P. A further examination of the risk-return characteristics of portfolios combining commodity futures contracts with common stocks. Center for the Study of Futures Markets, Columbia University, January 1987. Working paper.

HIGGINS, R.C. Analysis for financial management. 4.ed. Richard D. Irwin, Inc., 1995.

HOEL, P.G. Introduction to mathematical statistics. 4.ed. John Wiley \& Sons, 1971.

HUANG, C.; LITZENBERGER, R.H. Foundations for financial economics. Elsevier Science Publishing, 1988. p.365.

IRWIN, S.H.; KRUKEMYER, T.R.; ZULAUF, C.R. Investment performance of public commodity pools: 1979-1990. The Journal of Futures Markets, v.13, n.7, p.799-820, 1993.

JORION, P. Value at risk: a nova fonte de referência para o controle do risco de mercado. São Paulo: Bolsa de Mercadorias \& Futuros, 1998. p.306.

KEYNES, J. M. A treatise on probability. Londres: Macmillan, 1921.

KNIGHT, F. Risco, incerteza e lucro. Rio de Janeiro: Expressão e Cultura, 1972. p.385.

LEE, C.F.; LEUTHOLD, R.M.; CORDIER, J.E. The stock market and the commodity futures market: diversification and arbitrage potential. Financial Analysts Journal, p. 53-60, July/Aug. 1985.

LEITE, H.P.; SANVICENTE, A.Z. Índice Bovespa: um padrão para os investimentos brasileiros. São Paulo: Atlas, 1995. p.140.

LINTNER, J. The potential role of managed commodity-financial futures accounts (and/or funds) in portfolio of stocks and bonds. In: PETERS, C.; WARWICK, B. (Ed.) The handbook of managed futures: performance, evaluation and analysis. Irwin Professional Publishing, 1997. Part one, chapter 5, p. 99-138.

MARKOWITZ, H.M. Portfolio selection. The Journal of Finance, v.7, n.1, p.77-91, Mar.1952.

MARKOWITZ, H.M. Portfolio selection: efficient diversification of investments. New York: John Wiley \& Sons, 1959. p.343.

NAKAMURA, W.T. Eficiência da carteira teórica do índice Bovespa no contexto da moderna teoria de carteiras. São Paulo, 1998. 344 p. Tese (Doutorado) - Faculdade de Economia, Administração e Contabilidade, Universidade de São Paulo. 
ROSS, S.A.; WESTERFIELD, R.W.; JAFFE, J.F. Administração financeira. São Paulo: Atlas, 1995. p.698.

SCHNEEWEIS, T.; SPURGIN, R. The benefits of managed futures. In: PETERS, C.; WARWICK, B. (Ed.) The handbook of managed futures: performance, evaluation and analysis. Irwin Professional Publishing, 1997. Part one, chapter 2, p.17-48.

SECURATO, J.R. Cálculo financeiro das tesourarias: bancos e empresas. São Paulo: Saint Paul, 1999. p.450.

SECURATO, J.R. Decisões financeiras em condições de risco. São Paulo: Atlas, 1996. p.244.

SHARPE, W. Mutual fund performance. Journal of Business, p.119-138, Jan.1966.

SILVA, N.S. Usando commodities para diminuir o risco-retorno de um portfolio indexado. Resenha BM\&F, n.122, p.47-49, fev./mar.1998.

SIMONSEN, M. H. Dinâmica macroeconômica. São Paulo: McGraw-Hill, 1983. p.510.

TOBIN, J. Liquidity preference as behavior towards risk. The Review of Economic Studies, n.67, p.65-86, Feb. 1958. 